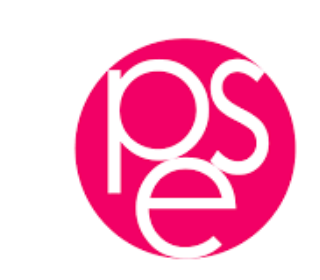

PARISSCHOOL OF ECONOMICS
ECOLE D'ECONOMIE DE PARIS

WORKING PAPER N ${ }^{\circ} 2020-08$

Who benefits from tax incentives?

The heterogeneous wage incidence of a tax credit

\author{
Clément Carbonnier \\ Clément Malgouyres \\ Loriane Py \\ Camille Urvoy
}

JEL Codes: D22, H25, H32

Keywords: business taxation; tax incentives; wage incidence; rent sharing

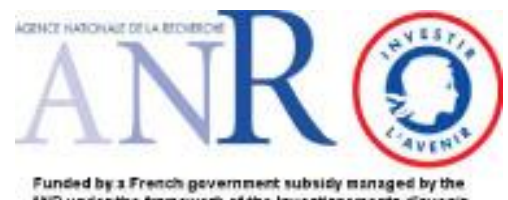

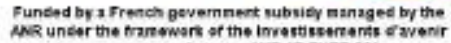




\title{
Who benefits from tax incentives? The heterogeneous wage incidence of a tax credit*
}

\author{
Clément Carbonnier ${ }^{\dagger}$ \\ Clément Malgouyres \\ Camille Urvoy \\ Loriane $\mathrm{Py}^{\S}$
}

February 29, 2020

\begin{abstract}
Do workers gain from lower business taxes, and why? We estimate how a large French corporate income tax credit is passed on to wages and explore the firm- and employee-level underlying mechanisms. The amount of tax credit firms get depends on their payroll share of workers paid less than a wage threshold. Exposure to the policy thus varies both across workers depending on their wage and across firms depending on their wage structure. Using exhaustive employeremployee data, we find that half of the surplus generated by the reform falls onto workers. Wage gains load on incumbents in high-skill occupations. The wage earnings of low-skill workers - nearly all individually eligible - do not change. This heterogeneous wage incidence is unlikely to be driven by scale effects or skill complementarities. We find that the groups of workers benefiting from wage gains are also more likely to continue working for the same firm. Further, we show that firms do not change their wage-setting behavior in response to the individual eligibility status of workers as there is no bunching in the distribution of entrants' wages. Overall, our results suggest that the wage incidence of firm taxation operates collectively through rent-sharing and benefits workers most costly to replace.
\end{abstract}

Keywords: business taxation; tax incentives; wage incidence; rent sharing

JEL codes: D22, H25, H32

Declaration of interests: None.

*A previous version of this paper was circulated under the title: "Wage Incidence of a Large Corporate Tax Credit: Contrasting Employee- and Firm-Level Evidence". We are grateful to Antoine Bozio, Thomas Breda, Michael Devereux, Marc Ferracci, Denis Fougère, Sergei Guriev, Camille Landais, Etienne Lehmann, Philippe Martin, Thierry Mayer, Benoit Ourliac, Bruno Palier, Thomas Piketty, Emmanuel Saez, Sebastian Siegloch, Etienne Wasmer and participants at AFSE, RES, EALE, LAGV, PET, IIPF, EEA conferences, IEB workshop on economics of taxation, PSE and Le Mans seminars for their comments. We also thank agents at CASD, Insee, DGFiP, ACOSS and Douanes for helping us with the data. This work is supported by public grants overseen by the French National Research Agency (ANR) as part of the "Investissements d'avenir" program within the frameworks of the Centre d'accès sécurisé aux données - CASD (ANR-10-EQPX-17) and the LIEPP center of excellence (ANR-11-LABX-0091, ANR11-IDEX-0005-02) and by France Strategie. Malgouyres acknowleges financial support from the ANR through project ANR-19-CE26-0004. The views expressed in this paper do not necessarily reflect those of the Banque de France or the Eurosystem.

†Université de Cergy-Pontoise, THEMA; Sciences Po, LIEPP; Banque de France

Institut des politiques publiques

${ }_{\text {Banque de France; Institut des politiques publiques }}$

`Sciences Po, Department of Economics; Sciences Po, LIEPP 


\section{Introduction}

In a context of growing fiscal competition between governments, many policymakers attempt to stimulate economic activity, create jobs and boost wages using business tax incentives. Over the past decades, many advanced economies have decreased firms' tax burden by cutting tax rates, ${ }^{1}$ or through targeted tax incentives such as tax credits that link fiscal expenditures with specific firm outcomes. ${ }^{2}$ The 2017 Tax Cuts and Jobs Act is a recent illustration of this phenomenon that has brought attention on the distributional consequences of tax incentives, and in particular on whether it benefits workers.

Yet, while the literature has documented some wage gains for workers as a group, little is known about which workers benefit from these tax incentives (Slattery and Zidar, 2020). Auerbach (2018) stresses that the recent growth in earnings inequalities compels an investigation into the distribution of the business taxation burden across workers. Does tax policy incidence vary across groups of workers? And if so, is it influenced directly by the design of the policy - which might be targeting a subset of workers - or by other mechanisms?

In this paper, we contribute to answer this question by studying the wage impact of a large French corporate income tax credit and by investigating the underlying worker and firm-level mechanisms. This tax credit is proportional to the payroll share of employees paid less than a wage threshold. The policy thus creates variation across workers - depending on which side of the wage threshold they fall - and across firms depending on their wage structure which determines the size of the overall windfall. The design of the policy thus provides a unique opportunity to disentangle the role of individual eligibility from firm-level mechanisms in shaping the pass-through of business taxes into wages.

First, we estimate at the firm-level that around half of the tax credit falls onto workers through higher wages. Yet, the wage incidence is not uniform within the firm: high-skill workers benefit from higher wages, low-skill workers do not. We then show that the tax credit does not affect relative employment share by skill-level. The distributive effect we uncover is thus unlikely to be driven by complementarity with

\footnotetext{
${ }^{1}$ Corporate income tax rates in most advanced economies have experienced downward trends. The 2017 Tax Cuts and Jobs Act reduced the US statutory corporate income tax rate from $35 \%$ to $21 \%$, continuing the decline in the effective tax rate over the past 25 years. Similar downward trends of corporate income tax rates are under way in Europe (Auerbach, 2018).

${ }^{2}$ Firm-specific and targeted tax incentives are numerous and have large budgetary impacts. Serrato and Zidar (2018) document that tax base rules and credits explain more of the variation in state corporate tax revenues than tax rates do. Slattery and Zidar (2020) show that in 2014, tax incentives for firms in the form of firm-specific subsidies and general tax credits amounted to nearly $40 \%$ of state corporate tax revenues in the United States. In France, corporate income tax credits - incentivizing a host of activities, from $R \& D$ to charities etc - accounted for about $43 \%$ of gross CIT income in 2015 , including the policy we study in this paper.
} 
low-skill workers, but rather points at firm-level surplus sharing. We then show that worker-level eligibility does not drive the distributive effect of the tax credit. We find no bunching in the distribution of new hires' wages near the threshold: firms did not hire more eligible workers eligible. Overall, our results suggest that part of the policy surplus is collectively shifted onto groups of workers through rent-sharing, a process that benefits mainly groups of workers with more bargaining power. We find a significant raise in the workforce retention rate - the share of workers who remain employed in the same firm - for high-skill workers who alone benefit from wage increases. It suggests that cost of replacement might be an important driver of bargaining power.

The tax credit we study, labelled as $\mathrm{CICE},{ }^{3}$ provides a quasi-natural experiment allowing to identify the distributive effects of tax incentives and to understand their underlying mechanisms. First, as mentioned above, the design of the policy is such that the amount of tax credit firms get is a fraction of the sum of gross wages of workers paid less than 2.5 times the minimum wage. It thus conveniently creates variation not only across otherwise similar workers on both sides of the eligibility cut-off, but also across firms with different wage structures around the threshold. Next, the policy and its distinct features were not anticipated. The tax credit was implemented starting in 2013 based on a law voted in December 2012 supported by a government elected in May 2012. It applied to all firms and jobs, whether pre-existing or newly created. Take-up by firms was quick and large as dedicated features were rapidly added to common accounting software packages. It resulted in a large fiscal expenditure. In 2015, it amounted to 18 billion euros, which is almost 30 percent of gross corporate income tax revenues. ${ }^{4}$

We combine several administrative data sets to investigate the wage and employment effects of this policy. First, we use firm-level administrative data on the amount of tax credit each firm received under the CICE policy. Second, we use matched employer-employee data on the universe of French private sector employees, providing rich information on the wages and hours worked. We finally use tax return data on the financial results of firms that obtained tax credits. We can thus conduct several empirical analyses, both at the firm- and at the worker-level, to study the distributional impact of this tax credit.

In the first step of our analysis, we study the wage incidence of the tax credit at the firm-level. We identify the causal link between firms' mean hourly wage and the tax credit by exploiting the discontinuity in the schedule: firm-specific decreases in taxes are proportional to payroll share of employees paid less than 2.5 times the minimum

\footnotetext{
${ }^{3} \mathrm{CICE}$ stands for Crédit d'Impôt pour la Compétitivité et l'Emploi in French or Competitiveness and Employment Tax Credit.

${ }^{4}$ Gross corporate income tax revenues refer to the corporate income tax revenues before tax credits, with the CICE being the largest corporate income tax credit, which corresponded in 2015 to a fiscal expenditure of 271 euros per French individual.
} 
wage. ${ }^{5}$ To isolate the firm-specific variation that directly stems from this worker-level discontinuity, we compare, in an augmented difference-in-differences framework, the wage policy of firms that have similar pre-reform wage distributions, except immediately around the eligibility cut-off. To provide support for our identification strategy, we document that, within groups of similar firms, variation in policy exposure remains large $e^{6}$ and is nearly as good as random as treatment intensity is uncorrelated with a series of pre-reform observable firms' characteristics.

We find a significant firm-level incidence of the tax credit on wages that unfolds gradually over time. More particularly, a 1 percentage point increase in the tax credit rate translates into a $0.5 \%$ increase in the mean hourly wage at the firm level. It suggests that $50 \%$ of the tax credit goes to workers. The magnitude of our estimate is in line with a recent body of work measuring the incidence of corporate income taxes using other sources of variation (Arulampalam et al., 2012; Suárez Serrato and Zidar, 2016; Fuest et al., 2018). This result is robust to alternative specifications.

Next, we show that while the policy caused wage gains on average, the firm-level wage incidence markedly differs across workers. The tax credit increases the wages of high-skill workers but has no impact on low-skill employees'. This distributional effect is particularly striking as it is at odds with the policy's targeting. In other words, low-skill workers, who are virtually all eligible, benefit from no wage increase while high-skill employees, who are less likely to be eligible, benefit from higher wages. The policy thus increases within-firm wage earnings inequalities. We also find that only incumbent employees benefit from wage gains, not entrants. These results suggest that the surplus generated by the policy is shared within the firm differently across groups of workers.

Further, we find no discernible effect of the tax policy on firm-level employment, nor on sales; firms do not expand, suggesting wage gains are not driven by scale effects. There are no employment effects in both skill groups: the heterogeneity in policy's pass-through effects is not driven by skill complementarity. As such, standard labor market mechanisms do not seem to provide an adequate framework for our findings.

The second part of our analysis considers worker-level incidence. We explore whether the individual eligibility status of workers impacts the policy pass-through. Canonical competitive labor market models predict that wages adjust through market mechanisms. Labor demand being more elastic than labor supply, the change in labor cost generated by the tax reform should be passed on to eligible workers' wages. The

\footnotetext{
${ }^{5}$ Henceforth we refer to employees paid less than 2.5 times the minimum wage as eligible employees for simplicity.

${ }^{6}$ In other words, due to the notch, among firms with similar wage distribution around the eligibility threshold, local differences in the share of workers right below or above that threshold can translate into substantial differences in the degree of exposure to the policy.
} 
notch in the reform schedule implies a sharp discontinuity in the labor cost of workers on both sides of the wage threshold. Labor demand for eligible workers should therefore immediately adjust. To formally test for this mechanism, we build on the bunching methodology developed by Kleven and Waseem (2013) and Chetty et al. (2011) and test for the presence of an excess mass of new hires paid just below the eligibility cut-off. We graphically document an absence of bunching both before and after the reform. This finding does not result from downward wage rigidity. Complementary estimations corroborate this result, thus invalidating the idea that firms reacted to the tax reform by increasing their demand for eligible employees.

Overall, our findings point to a substantial firm-level incidence of the tax reform on wages that spills over onto ineligible workers together with an absence of adjustment to the policy through employee-level mechanisms. A similar pattern has been documented in a different policy environment by Saez et al. (2019) who study Swedish payroll tax cut targeting young workers. ${ }^{7}$ These results can be rationalized as follow: first, the tax reform generates firm-specific surpluses that are shared across capitalowners and groups of employees through rent-sharing, which provides a rationale for treatment spilling over onto ineligible workers. Next, within groups of workers, incidence is collective, which explains the absence of employee-level response. Wage incidence however vastly differs across groups of workers. A potential explanation is that employers increase the wage of employees most costly to replace, here high-skill incumbents, in order to retain them (Kline et al., 2019). In line with this hypothesis, we document that the policy increased the workforce retention rate of high-skill workers but not that of low-skill workers.

Related literature. Our paper contributes to several bodies of research. First, we contribute to the literature studying the incidence of business taxes on wages by causally documenting a sizable impact of a tax reform on wages. We find that around $50 \%$ of the surplus generated by the tax credit is shifted onto workers. The magnitude of this effect is in line with a growing literature on corporate income taxes that finds that labor bears between $30 \%$ and $50 \%$ of the tax burden. Papers in this literature have exploited several types of variation in corporate income tax rates: variation across industries (Liu and Altshuler, 2013), across US states (Suárez Serrato and Zidar, 2016), across German municipalities (Fuest et al., 2018), across European or OECD countries in Europe (Arulampalam et al., 2012; Azémar and Hubbard, 2015). We leverage a nation-wide policy in France, ruling out within-country firm or labor mobility as important drivers

\footnotetext{
${ }^{7}$ They conclude to the absence of wage incidence at the employee level along the age eligibility threshold, but find evidence of firm-level rent-sharing as firms benefiting more intensely from the reform increase wages for both eligible (young) and ineligible (old) workers.
} 
of our results. Moreover, we compare firms belonging to the same narrowly-defined industry.

By documenting the heterogeneous incidence of this reform across occupational groups of workers, we also address the shortcoming pointed out by Auerbach (2018), who stressed that most papers have so far implicitly considered wage earners as a "monolithic group". We show that the tax credit essentially benefited skilled workers, suggesting heterogeneity in occupation is indeed a crucial element. Fuest et al. (2018) study changes in local business tax rates and investigate heterogeneity across groups of workers as well. They find that low-skill workers were the most penalized by tax increases. We discuss how our results relate to theirs in greater details in Section 6.

Second, although the tax credit we study defines eligibility at the employee level, the surplus generated by the reform is mainly passed on to wages at the firm-level. This finding challenges canonical models of tax incidence that posit that tax incidence is driven by market level mechanisms impacting workers' wages individually (see Anderson and Meyer, 1997, section 2). We contribute to a burgeoning strand of the literature documenting that firm-level mechanisms, rather than individual eligibility, play a key role in shaping tax incidence on wages. For instance, Bosch and MicevskaScharf (2017) and Bozio et al. (2017a) conclude to the absence of payroll tax wage incidence at the employee-level. ${ }^{8}$ Our findings are most closely related to Saez et al. (2019), who study a payroll tax cut targeted at young workers in Sweden. They uncover an absence of individual-level incidence while evidencing a substantial wage incidence at the firm-level. Where the windfall generated by the reform was largest, nearly all workers benefited from wage increases. We rely on a corporate income tax credit whose amount depends on employees' eligibility determined individually according to their wage. Unlike Saez et al. (2019), we detect no employment effect due to the reform. We can therefore rule out that the increase in high-skill workers' wages is driven by complementarities with low-income, low-skill workers. These results thus further strengthen the case for a bargaining mechanism. Overall, our work shows that a policy whose legal targeting is progressive ends up benefiting higher-wage workers through rent-sharing. This highlights the need to finely understand the role firms have in shaping primary inequalities in order to predict the redistributive effect of business tax reform.

Finally, our paper relates to the strand of literature in labor economics highlighting the role of firms in shaping labor market inequalities (Card et al., 2018). We contribute to this literature by estimating how a tax reform generating a profit windfall is par-

\footnotetext{
${ }^{8}$ In a recent article, Bozio et al. (2017b) find that the wage incidence of social security contributions in France depends on tax-benefit linkages: there is no effect on net earnings of an increase in health and family contributions - with no contributory link between contributions and benefits - while the incidence of pension contributions - with a clear contributory link - largely falls on workers. The tax credit we analyze in this paper has no contributory link.
} 
tially shifted onto workers' wages. Most papers so far have used observational variation in productivity (Guiso et al., 2005) or quasi-experimental research design relying on proxies likely to affect the rents earned by the firm, such as idiosyncratic demand shocks (Garin and Silvério, 2019) or patents (Kline et al., 2019). Most closely related to our paper is Howell and Brown (2019) who study how the R\&D grants to small firms affects wages. They find that R\&D grants lead to an increase in wages that is too large to be fully explained by firm growth, thus suggesting rent sharing is taking place. Like them, we find positive wage effect associated with the tax credit but no effect on employment growth thus directly pointing at rent sharing. Although we consider a reform that affected most firms in the economy as opposed to the select subset of small innovative firms they look at, we find broadly similar patterns. ${ }^{9} \mathrm{We}$ find no discernible effect on employment but a strong wage incidence concentrated among high-skill incumbents whose retention rate increases significantly with no effect on the wage of new entrants. Taken together these findings are broadly consistent with monopsony-type models in which firms set wages unilaterally and where rents are shared only because of information asymmetries (Card et al., 2018; Lamadon et al., 2018) and where that mechanism is mostly at play with respect to incumbents workers' outside options implying that the intensity of rent-sharing is particularly strong among these workers - in particular when they are costly to replace (Kline et al., 2019).

Outline of the paper. The rest of the paper is organized as follows. Section 2 presents the policy while section 3 details the data sources we use. The firm-level identification strategy and results are described in Section 4. Section 5 investigates employee-level incidence. Section 6 discusses our main results and situates them in the literature. Section 7 concludes.

\section{Institutional setting}

In this section, we detail the main features of the French tax credit studied here as well as its broader institutional setting.

Schedule. The Competitiveness and Employment Tax Credit (CICE henceforth) is a refundable corporate income tax credit. It was introduced on January $1^{\text {st }} 2013$. The amount of tax credit firms can claim depends on their wage structure. More precisely, it is equal to a fraction of the wage bill accruing to workers paid below 2.5 times the minimum wage (noted 2.5 MW below). All employees paid up to $2.5 \mathrm{MW}$ trigger a

\footnotetext{
${ }^{9}$ Unlike Howell and Brown (2019), we can measure hourly wage - as opposed to total compensation - which is a more direct measure of wage rate. A limitation of our study is that we cannot examine how the effect varies among incumbents depending on the length of tenure in the firm (see Section 3).
} 
corporate income tax credit equal to $4 \%$ of their annual wage in 2013 and to $6 \%$ of their annual wage in 2014 and 2015, while all employees paid more than $2.5 \mathrm{MW}$ trigger no tax credit.

Worker and firm exposure. This cut-off implies variation in exposure to the policy at two levels: across employees and across firms. First, the sharp wage cut-off induce substantial variation in workers' individual eligibility, especially among highskill workers. Figure 1 depicts the distribution of hourly wages relative to the minimum wage by occupation. ${ }^{10}$ The red vertical line represents the eligibility cut-off. While virtually all clerks and blue collars earn wages below the $2.5 \mathrm{MW}$ cut-off, a substantial share of managers and professionals earn above this threshold.

Second, this cut-off implies variation at the firm level depending on firms' share of eligible employees. Figure A1 plots the distribution of firms' exposure to the policy by firm size. Exposure to the policy is defined as the amount of tax credit each firm claimed divided by its wage bill as of 2013 . The spike at $4 \%$ is constituted of firms the most exposed to the policy: all their employees are paid less than $2.5 \mathrm{MW}$ and are eligible to the policy. The amount of tax credit they receive is therefore equal to 4 percent of their wage bill. The policy exposure distribution also exhibits a long left tail with substantial variation in the amount of tax credit that firms could claim, implying firms were heterogeneously affected by the policy.

Timing of benefits. The CICE is a tax credit, which entails a delay between the time wages are paid (and opens rights to the CICE) and the time when a firm benefits from the tax credit. Profitable firms get the tax credit at the end of the policy's first year, when paying corporate income taxes. Firms that are not profitable and thus pay no corporate income tax benefit from the tax credit after three years as a payment from the government, or after one year if they qualify as SMEs. It implies that all firms, profitable or not, benefit from this tax credit, but at different time according to their profitability and size. For simplicity and because profitability and size could be endogenous to the policy, we only consider how much tax credit a firm is entitled to, rather than how much it actually benefited from, to measure their exposure to the policy.

\footnotetext{
${ }^{10}$ As in Caliendo et al. (2015), we split workers into groups according to their occupational category. The first group includes senior staff, professionals, associate professionals, technicians, and employees at the supervisor level, corresponding to classes 3 and 4 of the French occupational classification system. The second category encompasses clerical employees and blue-collar workers, i.e. classes 5 and 6 . We refer to these groups as, respectively, managers and professionals and clerks and blue-collars for brevity. Given that occupational categories also correspond to different skill levels, we interchangeably refer to these two groups as high-skills and low-skills respectively.
} 
Figure 1: Distribution of wages by occupation

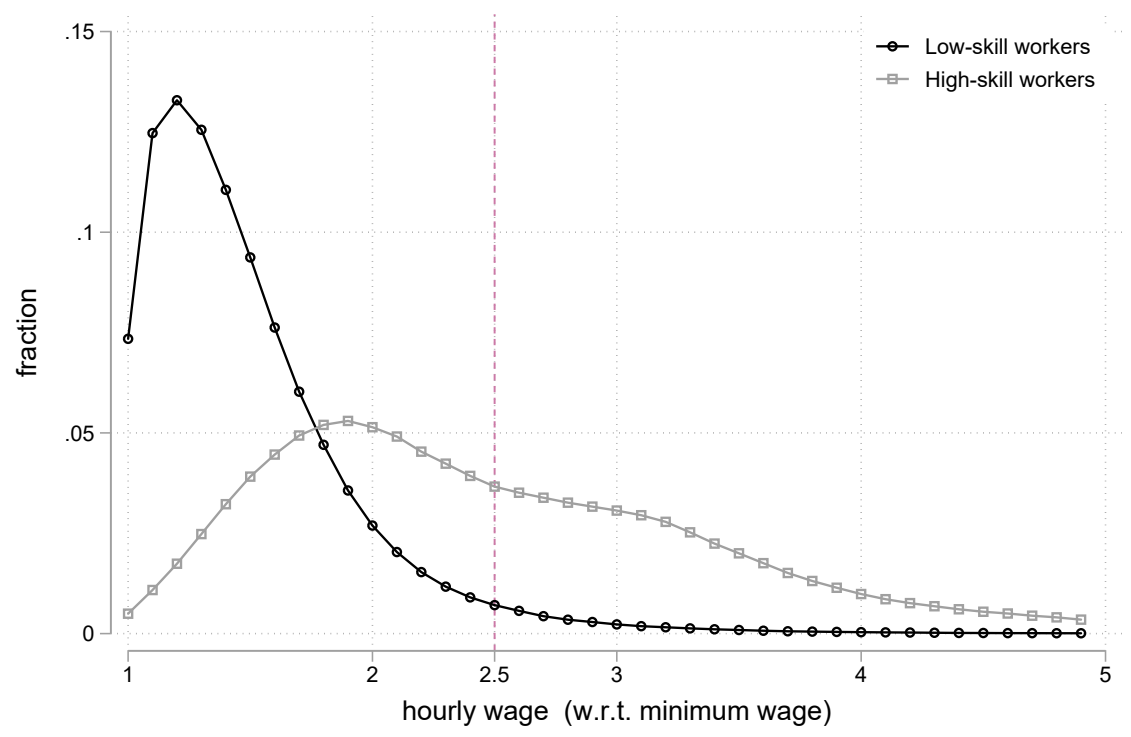

Notes: The figure plots the 2012 distribution of hourly gross wages of workers by occupation. The sample is restricted to workers employed in firms present in our estimating sample (see section 3.4 for details on the estimation sample). Each dot represents the fraction of workers in an interval of length 0.1 minimum wage.

Anticipations. Firms did not anticipate this policy as it was implemented short after a new government was elected, it was not part of the winning candidate's platform. Indeed, in 2012, a new French government came to power, in the context of an economic slowdown. This new government commissioned a working group to issue a report on how to tackle high unemployment and bolster French firms' performances. ${ }^{11}$ It advocated for payroll tax cuts up to $3.5 \mathrm{MW}$ in the manufacturing sector to boost firm competitiveness. This cut-off was chosen to target exporting firms, as they pay higher wages on average. Deemed too high by labor economists on the ground that the elasticity of labor demand is low for high-wage employees, the cut-off was eventually brought down to $2.5 \mathrm{MW} .^{12}$ Moreover, little time elapsed between the release of the report - November $5^{\text {th }} 2012$ - and the implementation of the CICE beginning January $1^{\text {st }} 2013$, making any anticipation effects quite unlikely.

Take up. The take-up was high. First, since most firms have at least one employee paid below 2.5 MW, they are almost all eligible to the tax credit. Second, implementation was made easy as accounting software packages rapidly included new features dedicated to the policy. Third, workers' wages, the only criterion for eligibility, is directly observed by firms. As a result, a very large share of French firms benefited from

\footnotetext{
${ }^{11}$ This report is often referred to as the Gallois Report in journalistic debates, after the name of Louis Gallois a businessman who chaired the working group.

${ }^{12}$ See Fabre (2012) for a journalistic account of the debate just before the adoption.
} 
the tax credit. For this reason, we decide to study firms differently exposed to the policy given their ex ante wage structure rather than compare firms that claim the tax credit to those that do not.

Other policies. The CICE follows other policies aimed at creating fiscal incentives for firms to increase hires, mainly payroll tax cuts. These policies however targeted workers paid significantly lower wages. Pre-existing payroll tax cuts targeted low wages, and amounted to about 26 percent of the gross wage at the minimum wagelevel, gradually decreasing to reach zero at $1.6 \mathrm{MW}$. In contrast, the CICE's tax credit rate is flat up to $2.5 \mathrm{MW}$, and sharply falls down to 0 above this threshold. The 2.5 MW eligibility cut-off is specific to this policy, and significantly different from past thresholds. Accordingly, exploiting this discontinuity to identify the reform's impact should not pick up the effect of another policy. In 2016, new payroll tax cuts targeting workers with wages up to $3.5 \mathrm{MW}$ were implemented. We therefore end our analysis in 2015 as these new tax incentives may affect our identification strategy.

Budgetary impact. The CICE had sizable budgetary consequences. The direct cost of the policy was 18.1 billion euros in 2015, which is equivalent to .82 percent of GDP, 30 percent of corporate income tax gross revenue, and 272 euros per capita. ${ }^{13}$ This quantitatively large policy was financed by several measures affecting households rather than firms, such as increases in VAT rates. ${ }^{14}$ Although labor market outcomes may be affected by these contemporary measures through general equilibrium, the discontinuity in the tax schedule we leverage for identification is unrelated to these simultaneous reforms. Moreover, we absorb aggregate shocks by using year or sector - year fixed-effects and focusing on firms and individuals directly affected by the discontinuity.

\section{Data}

We use information from three administrative sources. Matched employer-employee data come from social security declarations. Data on firms' financial performances come from corporate income tax returns and data on the amount of tax credit each firm claimed come from the public finance administration. In this section, we describe the data sources and detail the matching procedure as well as the characteristics of the resulting estimating sample.

\footnotetext{
${ }^{13}$ The corporate income tax gross revenue is the corporate income tax before tax credits, whose major share is actually constituted by the CICE.

${ }^{14}$ The CICE necessitated public finance reforms to be funded. There is no unique funding scheme dedicated to CICE, the government actually funded it through the general budget, by decreasing a broad range of expenditure and by increasing some mandatory levies on households, mainly VAT.
} 


\subsection{Employer-employee data}

The main source on employment and wage is the DADS (Déclarations Annuelles des Données Sociales) data set. It is a matched employer-employee data set based on social security records which covers the universe of French firms and private sector jobs. Data are provided at the contract-level and contain information on gross and net wage earnings, hours worked, occupation, type of contract (short term or long term), as well as some employee characteristics (age, gender). Each firm is identified with a unique administrative number called SIREN that remains the same across years. It allows matching each employee to an employer and tracking firms' employment and wage policy over time. Each individual in the data set is assigned a unique identifier each year, which allows tracking individuals across employers within a year. While this identifier changes over time and therefore does not allow to track individuals across years, the characteristics of the employee's past year's contract are provided (past year's employer, wage, hours worked, etc.), which allows to know whether the individual changed firm or job and to compute year-on-year changes in wage earnings or hours worked. We use data for the years 2009 to $2015 .^{15}$

Based on gross wage earnings and hours worked, we compute the gross hourly wage of each employee. This allows us to determine precisely whether each employee is eligible to the tax credit based on whether her gross hourly wage is lower than 2.5 times the minimum wage. ${ }^{16}$ Aggregating across individual within a firm, we can compute the payroll share of employees paid less than the eligibility threshold. We thus precisely know both employees' and firms' exposure to the tax policy.

We also use this data set to build our main outcomes of interest. At the employeelevel, we compute employees' hourly gross wage earnings. We also compute wage growth for incumbent employees, which we defined as workers working in the same firm two years in a row under a permanent contract. ${ }^{17}$ At the firm-level, we compute the mean hourly gross wage earnings for all employees as well as for two broad sets of occupations. ${ }^{18}$

\footnotetext{
${ }^{15}$ The methodology and perimeter of the dataset underwent a major change in 2009.

${ }^{16}$ Gross wage earnings are defined as "all remunerations received by the employee under her contract of employment, before deducting compulsory contributions". It does not allow breaking down compensation by type (fixed salary, bonuses, etc.). The minimum wage in France is set in terms of gross hourly wage.

${ }^{17}$ In France, by law, employees with fixed-term contracts must receive a bonus at the end of their employment period equal to $10 \%$ of the amount received during the contract period. It is likely to impact the measured year-on-year hourly wage growth of employees with fixed-term contracts. We therefore decide to set aside fixed-term contract workers in the employee-level analysis of wage growth.

${ }^{18}$ Similarly, firm-level mean hourly wage excludes hours worked and compensations of workers with a fixed-term contract.
} 


\subsection{Tax credit data}

The amount of CICE tax credit claimed by each firm is documented in an ad-hoc file provided by the Public Finance Administration (DGFiP). This file is called the CICE MVC (Mouvements de Créances) dataset. The first vintage is 2013 as it corresponds to the first year the policy was implemented. The distribution of tax credit amounts is very skewed. Micro firms (less than 10 employees), receive on average 2,756 euros each year, SMEs (10 to 250 employees) get 24,492 euros. The 288 largest firms in the data set get a tax credit amount approximately equal to that of the 496,750 micro firms.

\subsection{Balance sheet data}

We use income statement and balance-sheet data coming from the FARE database. This dataset is built using the tax returns of firms and their social security declarations. This dataset covers the universe of firms, except those in the financial and agricultural sectors. It provides detailed information on firms' revenues and expenses. We use this database to build firm-level control variables: labor productivity (value added divided by average workforce) and assets (tangible and intangible). ${ }^{19}$

\subsection{Matching and final datasets}

From the three data sets mentioned above, we build two estimation samples: one at the firm level to study collective incidence (section 4), and one at the contract-level to study individual incidence (section 5). The two estimation samples include the same firms, only the unit of observation differs. Firms are matched using their administrative identifier (SIREN), and need to meet the following criteria:

1. Firms need to be in the three data sets. It implies that all firms in the estimation sample claimed the tax credit. Therefore, in our estimation sample, the take up rate is $100 \%$, by construction. We compare firms differently exposed the tax reform, conditionally on claiming the tax credit.

2. Firms need to exist over the whole 2009-2015 time period. We obtain a balanced sample of firms.

3. Firms need to be continuing employers. We keep only firms with employment equal to at least one full time equivalent each year. The firm-level mean hourly wage cannot be zero.

\footnotetext{
${ }^{19}$ This data set also includes data on measures of profits. However we do not use variables such as reported profits due to accounting issues. Indeed, firms were allowed to account for the tax credit either as a decrease of wage bill or as a decrease of corporate taxes. Firms should find the second option more attractive, as the first option inflates the corporate income tax base. Therefore, an increase in reported profits could either reflect an increased profitability, or an accounting procedure choice.
} 
4. Firms do not exhibit extreme values for the following measures: ratio of tax credit to wage bill, profit margin, assets per worker and mean hourly wage growth. We exclude firms that are in the top percentile in at least one year, as it is likely to reflect measurement errors.

The resulting dataset contains 325,329 firms that account for $64.6 \%$ of the total CICE credit in $2013 .^{20}$

We study two outcomes of interest at the employee-level: the gross hourly wage of new hires and the year-on-year variation in gross hourly wage of continuing workers. Both are expressed in logs. The outcome of interest at the firm-level is the firm weighted average hourly wage of workers with a permanent contract, working substantial hours (at least $60 \%$ of a full time) and who were already working for the firm the preceding year. Firm-level mean hourly wage is weighted by hours worked. ${ }^{21}$

\section{Firm-level Incidence}

In this section, we test whether workers benefit from tax incentive policies through higher wages, and if so whether all workers are impacted. We address this question by using firm-level variation in exposure to the tax policy generated by firms' prereform wage structure. We present in details our identification strategy in Section 4.1. We then present our main results showing workers on average substantially benefit from the tax policy through higher wages in Section 4.2. In Section 4.3, we show our results are robust to alternative specifications and tests. We then demonstrate, in Section 4.4, that the wage incidence sharply differs across groups of workers: although the policy is targeted at workers paid lower wages, only high-skill workers benefit from wage gains, low-skill workers do not. We finally document that the tax credit did not increase firms employment in Section 4.5.

\subsection{Identification strategy}

Treatment intensity. Our empirical strategy exploits the between-firm variation in exposure to the policy. Yet, a firm's exposure can be driven by its behavioral response to the policy itself. For example, if the tax credit causes a firm to hire more low-wage (eligible) workers, then its exposure to the policy will endogenously increase. For this reason, we firms' pre-reform wage structure to measure their exposure to the policy (as in Auten and Carroll, 1999; Saez et al., 2019). ${ }^{22}$ We define our treatment intensity vari-

\footnotetext{
${ }^{20}$ They account for almost identical shares for the following years: $64.3 \%$ in 2014 and $63.8 \%$ in 2015 .

${ }^{21}$ More detailed definitions of all variables used in the analysis are included in Section OA4 of the Online Appendix.

${ }^{22}$ Auten and Carroll (1999) use this method to estimate of the elasticity of taxable income. They apply the variation in the rate to the earned income the year preceding the reform.
} 
able as the pre-reform payroll share of workers paid less than $2.5 \mathrm{MW}$, scaled by the tax credit rate. It corresponds to the predicted effective tax credit rate. More formally, it writes:

$$
Z_{i}=\frac{\tau \cdot \sum_{j \in i} w_{j, t_{0}} h_{j, t_{0}} \cdot \mathbb{1}\left(w_{j, t_{0}}<2.5 M W_{t_{0}}\right)}{\sum_{j \in i} w_{j, t_{0}} h_{j, t_{0}}}
$$

where $w_{j, t_{0}}$ and $h_{j, t_{0}}$ denote the gross hourly wage and hours worked of employee $j$ in firm $i$ during the last pre-reform year denoted $t_{0} . \tau$ is time-invariant and is set to reflect the average rate of subsidy over the period (the mean of $4 \%$ in $2013,6 \%$ in 2014 and $6 \%$ in 2015 is $5.33 \%$ ).

Our choice of treatment intensity relies on the persistence of firms' wage structure across time. Figure 2 depicts the relationship between the payroll share of eligible workers following the policy implementation (2013-2015) and the payroll share of eligible workers in 2012, which we use to define our treatment intensity. The payroll share of eligible workers in 2013-2015 is measured as the payroll share of workers triggering a tax credit as backed out using the amount of CICE firms obtained and divided by the applicable rate (4\% in 2013 and 6\% in 2014 and 2015). It is then expressed as a share of the firm's payroll. The relationship is strongly positive and dots all lie close to the 45 degree line. A one percentage point increase in the 2012 payroll share of eligible workers is associated with a .76 percentage point increase in the 2013-2015 payroll share of workers opening rights to the tax credit. It implies there is substantial persistence in firms' wage structures across years. ${ }^{23}$

Exploiting the discontinuity to compare similar firms. As mentioned above, variation in treatment intensity across firms is driven by differences in wage structures. A potential challenge is that these differences are associated with unobservable firms' characteristics that impact firms' dynamics. To take an extreme example, firms employing only minimum wage workers are likely to differ from firms employing only high wage workers in fundamental ways, observable and non-observable, which are likely to result in biased estimates. The notch created by the policy at the 2.5 minimum wage-level is useful for identification. Ideally, we would like to compare the wage dynamics of firms whose employees are all paid just a little less than $2.5 \mathrm{MW}$ in 2012 to firms whose employees are all paid just a little more than $2.5 \mathrm{MW}$ as in a regression discontinuity type approach. This strategy is not feasible as no firms strictly match the required criteria. Instead, we approximate this approach by comparing firms with

\footnotetext{
${ }^{23}$ We focus on reduced-form estimates as they can be identified while remaining agnostic about the lag structure of the effect of the endogenous variable. On the contrary, the structural coefficients cannot be identified without making further restrictive assumptions. See section OA3 in the Online appendix for a formal exposition of this argument.
} 
Figure 2: Payroll share of eligible workers: pre- vs. post-reform

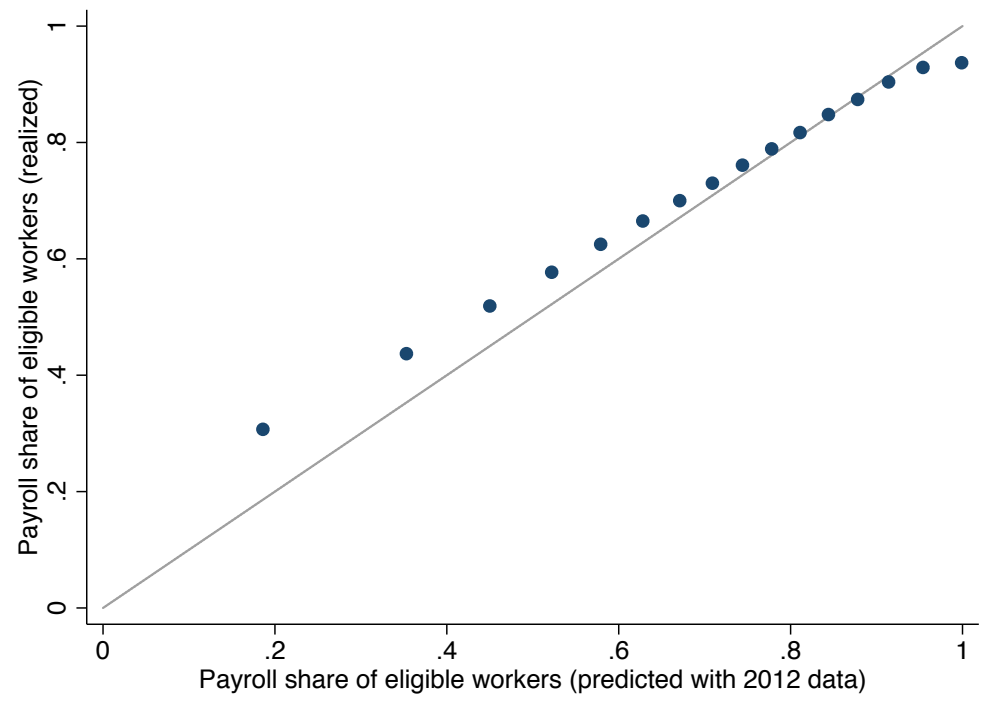

Notes: This binned scatterplot depicts the relationship between firms' payroll share of eligible workers as measured by the ratio of CICE amount over payroll divided by the applicable tax credit rate on the $y$-axis and the instrument on the $x$-axis. The instrument corresponds to payroll share of eligible workers predicted using 2012 wage structure. The right-hand side variable is grouped into 30 bins.

similar wage distribution, except just around the eligibility threshold, thus ensuring that variation in treatment is driven by local differences in wage distribution.

To this end, we group firms based on their wage structure as of 2012. For each firm, we compute the 2012 payroll share of workers paid less than 2.2 MW and the payroll share of workers paid less than $2.8 \mathrm{MW} .{ }^{24}$ We then discretize these shares, and interact them. Our preferred step to discretize payroll shares is 3.33 percentage points (30 categories), ${ }^{25}$ which yields $30 \times 30$ groups of firms that have a similar payroll share of workers paid less than 2.2 MW and a similar payroll share of workers paid less than 2.8 MW. We call these groups "bins". Within a bin, firms have a similar wage structure, except immediately around the eligibility threshold, they are thus similar but differently exposed to the tax policy.

Figure 3 provides a graphical illustration of our methodology. Firms in bin A have between $95 \%$ and $100 \%$ of their payroll going to workers paid less than $2.2 \mathrm{MW}$, they are intensely exposed to the CICE. To the opposite, firms in bin B have between $0 \%$ and $5 \%$ of payroll going to workers paid less than 2.8 MW. They are (almost) not exposed to the CICE. Firms in these two groups are very differently exposed to the policy, but also likely too different to be comparable. Instead, our methodology compares firms with a similar wage distribution, except immediately around the eligibility threshold.

\footnotetext{
${ }^{24}$ As a sensitivity test, we also set the bounds to $2.3 \mathrm{MW}$ and $2.7 \mathrm{MW}$.

${ }^{25}$ We additionally show that our results are robust to other parameters.
} 
Figure 3: Illustration of the bin method

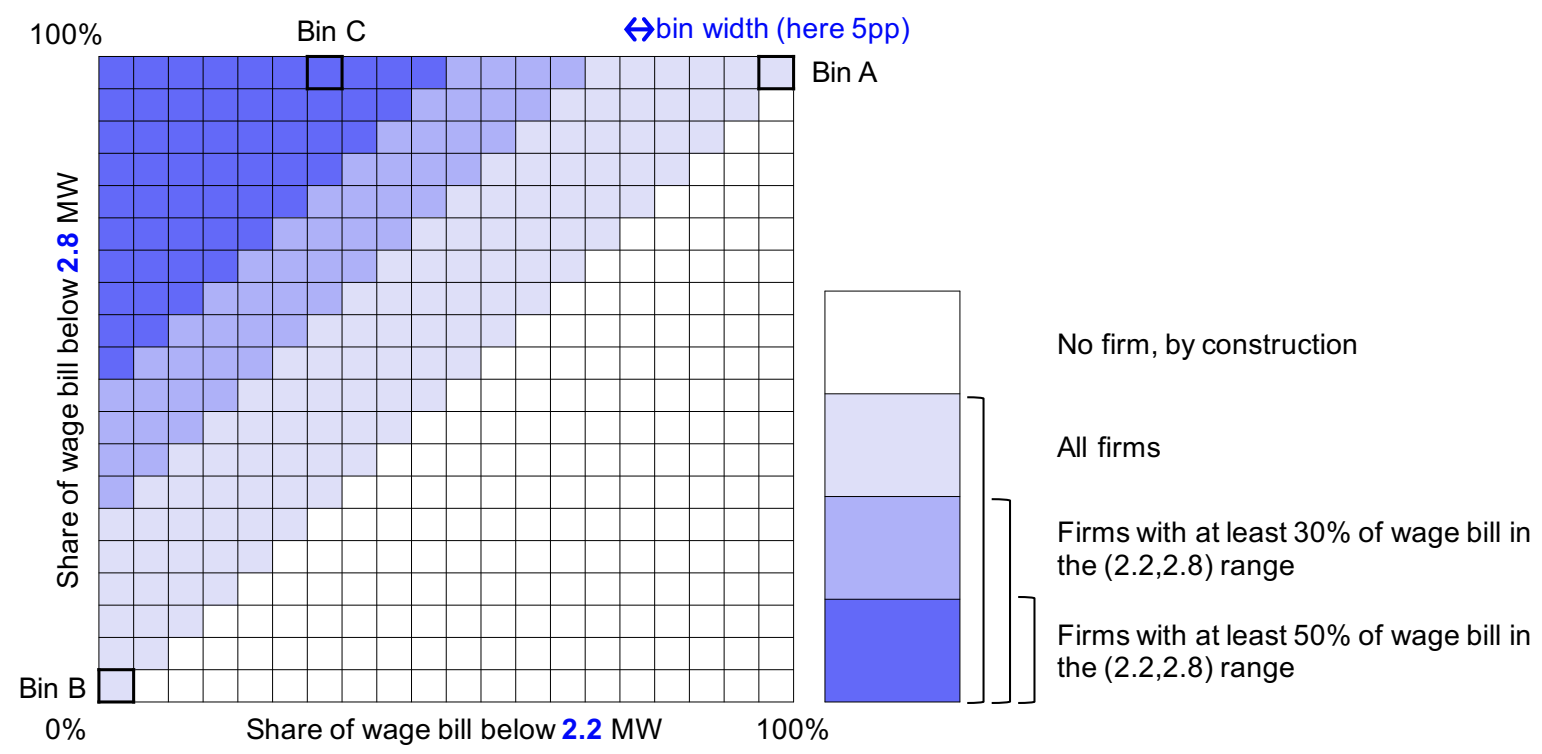

Notes: Firms in bin A have between $95 \%$ and 100\% of their wage bill accruing to workers paid less than 2.2 MW. Firms in bin B have between $0 \%$ and $5 \%$ of their wage bill paid to workers earning less than 2.2 MW. Firms in bin C have between 30\% and 35\% of their wage bill paid to workers earning less than 2.2 MW and between $95 \%$ and $100 \%$ of their wage bill paid to workers earning less than 2.8 MW. More than $50 \%$ of their wage bill accrues to workers paid between 2.2 and $2.8 \mathrm{MW}$. The bottom right hand corner contains no firm, by construction.

To ensure that within a bin, firms do vary in their policy exposure, we define two sub-samples of firms according to their payroll share of workers paid between 2.2 and 2.8 MW. The first sub-sample includes only firms for which this payroll share is at least $30 \%$, the second sub-sample includes firms whose payroll share is at least $50 \% .{ }^{26}$ We therefore exploit large across firms variations in policy exposure that derive from small variations in wage structure.

Figure A2, left panel, plots the cumulative density function of wages of all firms with at least $30 \%$ of their payroll share going to workers earning between 2.2 and 2.8 MW (in black). The blue (respectively grey) line corresponds to the same density function for firms with an above (below) median payroll share of eligible employees. Firms most exposed to the policy (blue) have a higher payroll share of low-wage workers than least exposed firms (grey). Figure A2, right panel, plots similar cumulative density function, except that above and below median treatment intensity groups are defined within each bin. It shows that firms in the two groups differ in their wage distribution only immediately around the eligibility cut-off. Their wage distributions are otherwise similar.

\footnotetext{
${ }^{26}$ These subsets are not representative of the full sample. They tend to include smaller, more productive and more skill intensive firms. Descriptive statistics are reported in Table A1.
} 
Table 1: Between/within bin variation in treatment

\begin{tabular}{lccccc}
\hline \hline Statistic & Sample & \# firms & Std deviation & Between Cells & Within Cells \\
\hline$\hat{\mathbb{V}}\left(Z_{i}\right)$ & all & 325,329 & 0.0094 & $92.0 \%$ & $8.0 \%$ \\
$\hat{\mathbb{V}}\left(Z_{i}\right)$ & $\%$ WB $>0.3$ & 30,089 & 0.0107 & $50.2 \%$ & $49.8 \%$ \\
$\hat{\mathbb{V}}\left(Z_{i}\right)$ & $\%$ WB $>0.5$ & 8,130 & 0.0120 & $27.6 \%$ & $72.4 \%$ \\
\hline \hline
\end{tabular}

Notes: A bin is defined as a unique value of the proportion of wage bill accruing to workers making less than 2.2 and less than $2.8 \mathrm{MW}$ (both variables are discretized through truncation into 31 values). A cell is defined a specific bin $\times$ sector $\times$ size category combination. "\% WB $>x^{\prime \prime}$ refers to a sample restriction to firms whose share of the wage bill constituted of wages between 2.2 and $2.8 \mathrm{MW}$ is above $x$.

Table A2 shows the pre-reform correlations between the instrument and firms' observables (firm's assets, labor productivity, share of low-wage employees) in Column (4). Column (5) plots the correlations between the residuals of the instrument and firms' observables after absorbing industry and size category fixed effects. Column (6) plots the equivalent correlations after absorbing sector $\times$ size $\times$ bins fixed effects. Controlling for industry and size fixed-effects only slightly reduces the correlation between firms' observables and the instrument. To the opposite, in the last column, the correlation between firms' observables and the instrument is significantly reduced. It suggests that within bin the variation in ex ante policy exposure is nearly as good as random.

Is within bin variation in exposure to the policy sufficient for identification? Table 1 shows how much variation in policy exposure remains after absorbing sector $\times$ size $\times$ bins fixed effects. In the full sample, only $8 \%$ of the variation in policy exposure is between firms of the same bin. Yet, for subsamples of firms that have a larger share of workers paid wages close to the wage cut-off, within bin variation in policy exposure is substantial. Within bin variance accounts for $50 \%$ of total variance (72\%) among firms with $30 \%$ (respectively $50 \%$ ) of their payroll share going to workers paid between 2.2 and $2.8 \mathrm{MW}$. Additionally, the total variance in these subsamples is larger than that in the full sample of firms.

Difference in Differences. Our main difference in differences specification writes as follows:

$$
\ln \left(Y_{i, t}\right)=\alpha_{i}+\alpha_{c, t}+\beta \cdot Z_{i} \cdot \mathbb{1}\{t \geq 2013\}+X_{i, t-1}^{\prime} \gamma+\varepsilon_{i, t}
$$

where $Y_{i t}$ is the mean weighted hourly gross wage earnings of employees in firm $i$ at time $t$. The term $\alpha_{i}$ refers to a firm fixed-effect, $\alpha_{c, t}$ corresponds to cell $\times$ year fixed effects. We defined cells as the interaction of bin categories with industry and size categories. The inclusion of cell $\times$ year fixed effects implies that we are comparing ex ante similar firms in terms of wage distribution at 2.2 and $2.8 \mathrm{MW}$, industry and 
size category. The common trend assumption needs only to hold within-cell. $Z_{i}$ is the instrument, it corresponds to the predicted policy exposure of the firm given its pre-reform wage structure, as defined in equation (1). $\mathbb{1}\{t \geq 2013\}$ is an indicator variable equal to one if $t \geq 2013$. The coefficient $\beta$ can be interpreted as a semi-elasticity of the variable $Y_{i, t}$ relative to the tax credit rate. We show in Appendix OA2 that this semi-elasticity can be interpreted as a close approximation of the share of the tax credit incidence borne by labor. The vector $X_{i, t-1}$ includes lagged observable controls (share of employees paid less than $1.5 \mathrm{MW},{ }^{27}$ assets (in log), and labor productivity (in log). Since our source of variation in treatment intensity is quasi-random, control variables should not affect point estimates, but might help improve the precision of our estimates. Standard errors are clustered at the firm level to account for serial correlation.

Event Study. To test for diverging pre-trends and assess how the effect unfolds overtime, we also implement an event study specification. It writes as follows:

$$
\ln \left(Y_{i, t}\right)=\alpha_{i}+\alpha_{c, t}+\sum_{\substack{d=2009 \\ d \neq 2012}}^{2015} \beta_{d} \cdot Z_{i} \cdot \mathbb{1}\{d=t\}+X_{i, t-1}^{\prime} \gamma+\varepsilon_{i, t}
$$

This specification is similar to 2, except the instrument is interacted with a full set of year dummy variables. 2012 is the reference year. Standard errors are clustered at the firm-level.

\subsection{Main results}

Graphical evidence. Figure 4 plots the evolution of the weighted gross hourly wage (base 1 in 2012) in two groups of firms, according to whether their policy exposure is above or below the within bin median. The two groups of firms have parallel trends prior to the reform and the group the most exposed to the policy experiences faster growth in mean hourly wages. In 2015 relative to 2012, wages in most-treated firms have grown by $4.20 \%$ and by $3.02 \%$ in least treated firms.

Difference in differences estimates. Table 2 presents the formal difference in differences estimation results corresponding to Equation 2. The outcome variable is the log of the weighted average of gross hourly wages of workers in a given firm. The first three columns of the table correspond to the full sample, the next three columns to the subset of firms with at least $30 \%$ of their wage bill accruing to workers paid between 2.2 and $2.8 \mathrm{MW}$ and the last three columns to the subset of firms with at least $50 \%$ of their wage bill in this window. In Columns (1), (4) and (7), regressions include year

\footnotetext{
${ }^{27}$ Another policy targeting these employees was implemented in 2015
} 


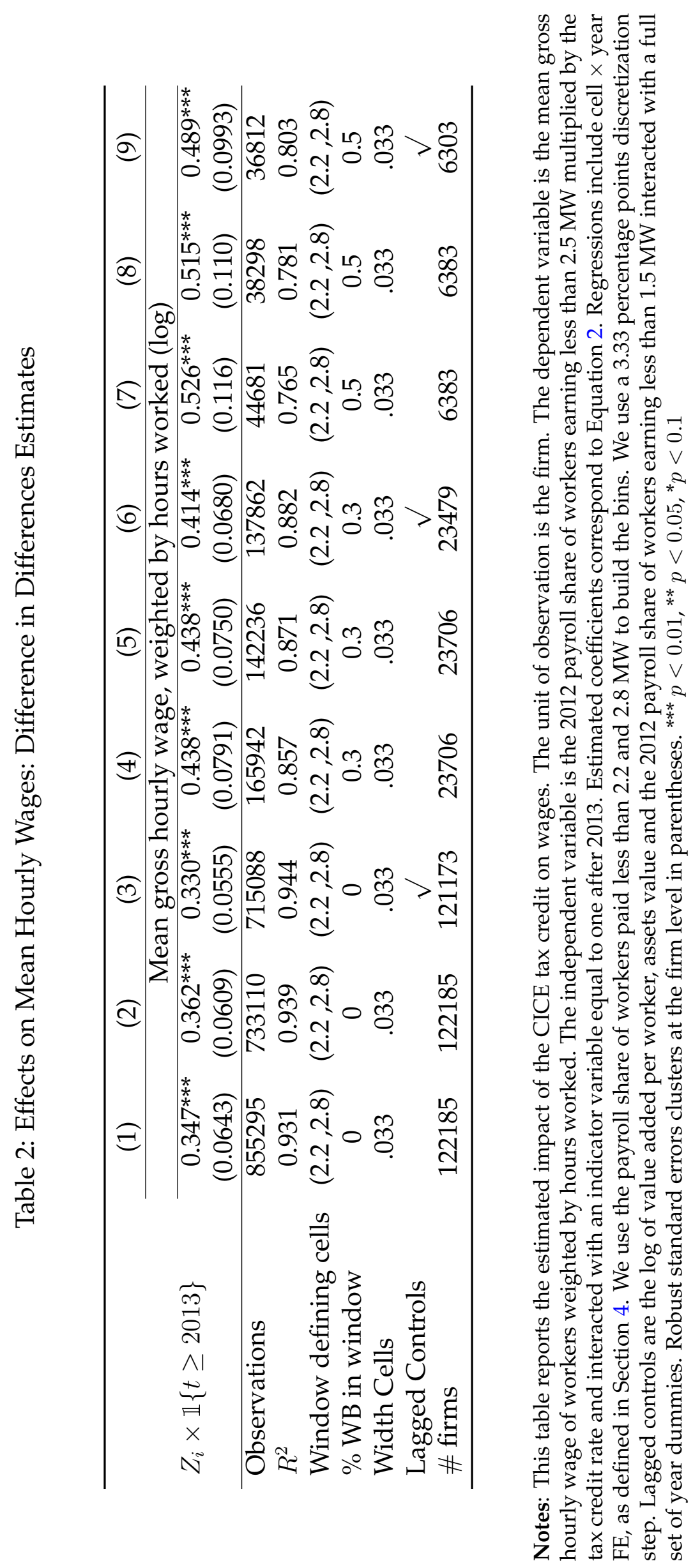


Figure 4: Firm-level impact on gross hourly wages

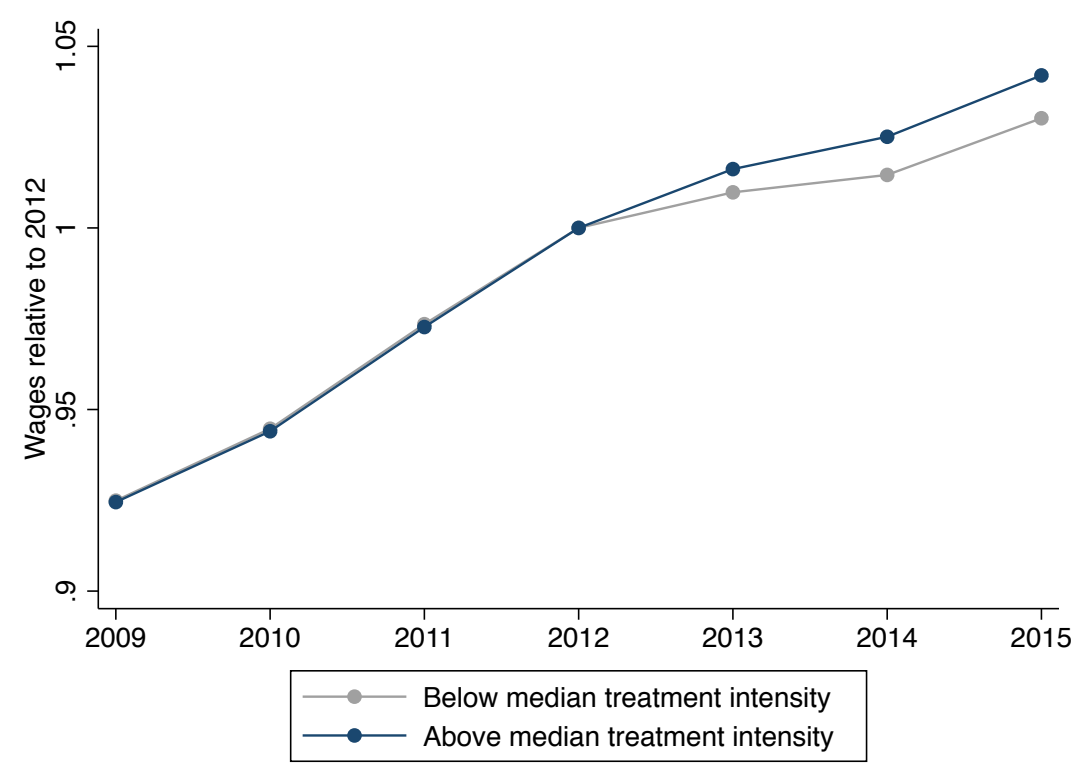

Notes: This figure plots the mean gross hourly wage of firms (relative to 2012) across a balanced sample of firms with at least $50 \%$ of their payroll paid to workers earning between 2.2 and $2.8 \mathrm{MW}$. We consider two groups of firms according to whether their 2012 payroll share of workers paid less than $2.5 \mathrm{MW}$ is above or below within-bin median. Bins are defined as detailed in Section 4. On average, the predicted effective rate of CICE of firms with an above median payroll share of eligible workers is $4.84 \%$. It is equal to $2.41 \%$ for firms in the other group.

2009 to 2015, other columns include year 2010 to 2015. Columns (3), (6) and (9) include lagged time-varying controls at the firm-level, other columns do not. Our preferred specification is that in Column (9) as the sample definition is the strictest and controls are included. We estimate a positive, sizable and statistically significant impact of the CICE on wages at the firm-level. An increase in the effective tax credit rate by 1 percentage point translates into a $0.49 \%$ increase in firms' average wage. More than half of the tax credit was passed on to workers through wage gains. ${ }^{28}$ The magnitude of the effect is close to that of other estimates in the literature on the wage incidence of the corporate income tax (Liu and Altshuler, 2013; Arulampalam et al., 2012; Fuest et al., 2018), which is around 50\%. For the US, Suárez Serrato and Zidar (2016) find that the corporate income tax wage incidence is around 30\%. Point estimates are stable across specifications and samples. They are all strongly significant.

Event study regressions. Figure 5 plots the estimation results of Equation 3 where dots correspond to point estimates and vertical bars to 95-percent confidence intervals. The specification chose corresponds to that of column (9) in Table 2. The outcome variable is the log of the weighted average of gross hourly wages of full-time workers at

\footnotetext{
${ }^{28}$ see Appendix OA2 for a simple derivation on the link between the estimated semi-elasticities and the labor share of the tax credit incidence.
} 
the firm-level. First, coefficients before 2012 are all close to zero and not statistically significant, confirming the absence of pre-trend. To the contrary, from 2013, we observe a large increase in mean hourly wages that unfolds gradually.

Figure 5: Effects on Mean Hourly Wages: Event Study Estimates

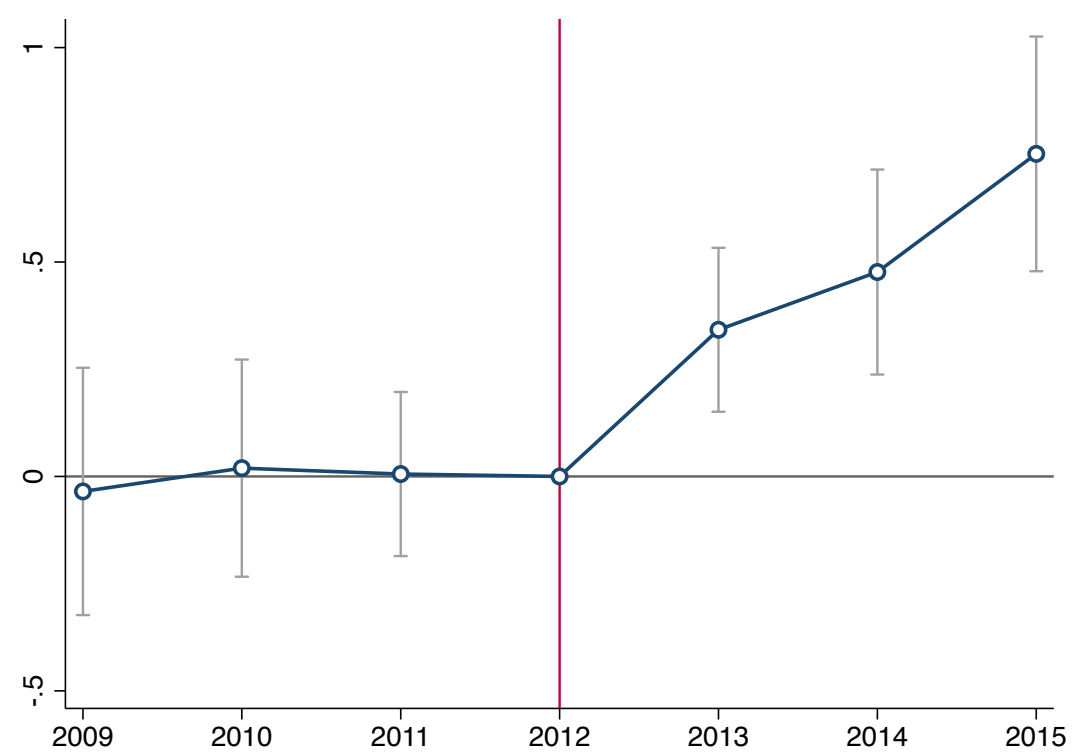

Notes: This figure plots the point estimates and 95-percent confidence intervals from the event study regression defined in Equation 3. The unit of observation is the firm. The dependent variable is the mean gross hourly wage of workers, weighted by hours worked, in logs. The independent variable is the 2012 payroll share of workers earning less than 2.5 MW multiplied by the tax credit rate and interacted with year dummies. 2012 is the reference year. The sample includes firms with at least $50 \%$ of their payroll paid to workers earning between 2.2 and 2.8 MW. Bins are defined as in Table 2. Robust standard errors are clustered at the firm level.

\subsection{Robustness}

Alternative definitions of bins. We first show that our results are robust to the size of bin we choose. Figure A3a plots event study estimates of Equation 3 as in Figure 5 , except that bin fixed effects are defined using alternative bin widths. The baseline bin width is 3.33 percentage points. Blue estimates correspond to a bin width of 2 percentage points. Black estimates correspond to a bin width of 5 percentage points. Corresponding difference in differences estimates are reported in Tables A3 and A4. Our results do not change. Coefficients remain non-significant pre-reform and become positive and significant after 2013 in all specifications. The magnitude of the effect is also very similar.

Next, we show that our results are robust to the wage thresholds we use to define bins. We have defined bins using the payroll share of workers paid less than 2.2 and 2.8 MW. We now compare our results with that obtained when using payroll share of 
workers paid less than 2.3 and 2.7 MW to define our bins. Figure A3b presents event study estimates using this alternative definition of bins. Tables A5, A6 and A7 report the corresponding difference in differences estimates. Results are similar. Pre-reform coefficients are not significantly different from zero while post reform ones gradually increase over time.

Alternative base year of the instrument. We use the pre-reform wage structure of firms to predict their exposure to the policy. We have use the year 2012, the year before the policy was implemented, to compute this instrument. Figure A4 plots event study estimates using other reference years to define our instrument. Again, our results are unchanged. Pre-reform coefficients are all close to zero and statistically non significant. Post reform coefficients gradually increase from 2013. The magnitude of the estimated coefficients is very close to that of the baseline in Figure 5. Tables A8 and A9 report corresponding difference in differences estimates and present coefficients very close to those presented in Table 2. Robustness to the year used to define the instruments and bins suggest that serial correlation is not a concern here. Indeed, some papers have documented that instruments à la Auten and Carroll (1999) could be affected by mean reversion (see Weber, 2014, for an application to the elasticity of taxable income literature).

Placebo. To further test the robustness of our empirical design, we implement a placebo test using a fictional policy schedule. Namely, we conduct our empirical analysis as if the tax credit amounted to a share of the payroll of workers paid less than 3.1 MW, instead of 2.5 MW in reality. We use 2.9 and 3.3 MW as wage thresholds to define bins. We set the new cut-off to 3.1 MW such that it is low enough to have sufficient local variation in the distribution of wages around it, but not too low so the widow used to define the bins does not overlap with our previous bounds. Figure A5 presents event study estimation results. Both pre- and post-reform coefficients are not statistically significant.

\subsection{Heterogeneity across workers}

Results so far show that, on average, workers benefited from the policy through substantial wage gains. In this section, we explore whether different groups of workers were affected to varying extents by the policy.

By skill level. A recent body of work has stressed the importance of occupations (Caliendo et al., 2015) to understand within-firm wage dynamics. Kline et al. (2019) posit that the wage premia of employees depend on the training and recruiting costs 
associated with their occupations. Employees least substitutable with new hires are paid higher wages. We split workers into two occupational groups based on the level of skills required. The first group includes senior staff, professionals, associate professionals, technicians, and employees at the supervisor level, corresponding to classes 3 and 4 of the French occupational classification system. ${ }^{29}$ The second category encompasses clerical employees and blue-collar workers, i.e. classes 5 and 6 . We refer to these groups as high-skill workers and low-skill workers respectively.

Figure 1 plots the distribution of gross hourly wage for these two groups in 2012. Low-skill workers are almost all paid less than $2.5 \mathrm{MW}$, implying they all open rights to the tax credit. High-skill workers are paid higher wages and $44 \%$ of them are paid more than 2.5 MW. Figures 6 plots the evolution of the weighted gross hourly wage (base 1 in 2012) in two groups of firms, separately for the high and low-skill workers. The two groups of firms - according to whether their policy exposure is above or below the within-cell median - have parallel trends prior to the reform and the group the most exposed to the policy experiences faster growth in mean hourly wages for high-skill workers but not for low-skill workers.

Figure 6: Firm-level impact on gross hourly wages, by skill group

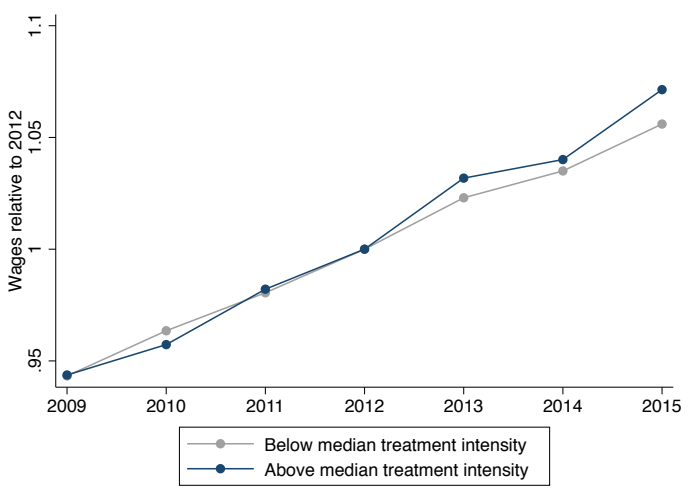

(a) High-skill workers

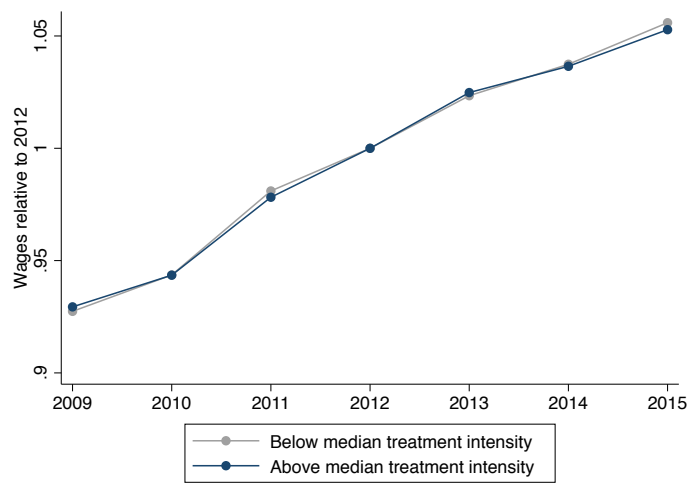

(b) Low-skill workers

Notes: This figure plots the mean gross hourly wage of firms (relative to 2012) across years for high-skill and low-skill workers, depending on firms' treatment intensity. Other notes as in Figure ??

Table 3 reports difference in differences regression estimates by skill groups. The outcome variable is the skill-specific mean gross hourly wages. The positive wage effects of the policy only benefit high-skill workers. A one percentage point increase in the tax credit rate increases the wages of high-skill workers by $0.6 \%$. By contrast, we find no effect of the policy on low-skill workers. Coefficients are all close to zero and precisely estimated.

\footnotetext{
${ }^{29}$ We group these two classes although they have been shown to be different (Caliendo et al., 2015) to have enough firms with at least one worker of this group every year over the period studied.
} 
Table 3: Heterogeneity across Skill Groups: Difference in Differences Estimates

\begin{tabular}{lccccccc}
\hline \hline & \multicolumn{3}{c}{ Mean gross hourly wage, weighted by hours worked (log) } \\
\cline { 2 - 4 } \cline { 7 - 8 }$Z_{i} \times \mathbb{1}\{t \geq 2013\}$ & \multicolumn{3}{c}{ Low-skill workers } & & \multicolumn{3}{c}{ High-skill workers } \\
\cline { 2 - 4 } \cline { 6 - 8 } & -0.047 & -0.048 & -0.087 & & $0.437^{* * *}$ & $0.420^{* * *}$ & $0.605^{* * *}$ \\
& $(0.078)$ & $(0.103)$ & $(0.163)$ & & $(0.102)$ & $(0.118)$ & $(0.157)$ \\
\hline Observations & 616,093 & 99,010 & 23,379 & & 528,764 & 91,246 & 23,245 \\
$R^{2}$ & 0.888 & 0.870 & 0.869 & & 0.866 & 0.826 & 0.765 \\
Window & $(2.2,2.8)$ & $(2.2,2.8)$ & $(2.2,2.8)$ & & $(2.2,2.8)$ & $(2.2,2.8)$ & $(2.2,2.8)$ \\
Bin width & $3.33 \mathrm{pp}$ & $3.33 \mathrm{pp}$ & $3.33 \mathrm{pp}$ & & $3.33 \mathrm{pp}$ & $3.33 \mathrm{pp}$ & $3.33 \mathrm{pp}$ \\
Sample & $>0 \%$ & $>30 \%$ & $>50 \%$ & & $>0 \%$ & $>30 \%$ & $>50 \%$ \\
Lagged controls & $Y e s$ & $Y e s$ & Yes & & Yes & Yes & Yes \\
\hline \hline
\end{tabular}

Notes: This table reports the estimated impact of the CICE tax credit on wages of workers by skill groups. The unit of observation is the firm. The dependent variable is the mean gross hourly wage of continuing workers of a given skill level, weighted by hours worked. The independent variable is the 2012 payroll share of workers earning less than $2.5 \mathrm{MW}$ multiplied by the tax credit rate and interacted with an indicator variable equal to one after 2013. Other notes as in Table 2.

Figure 7 plots the corresponding event study regression results. For both skill groups, pre-reform coefficients are close to zero, lending support to the common trend assumption. For high-skill workers, the effects of the policy on wages gradually unfolds. By contrast, the policy has no effect on wages for low-skill workers.

Our results have two implications. First, while the policy has a sizable effect on wages, this effect varies dramatically across groups of workers. It suggests that withinfirm mechanisms are crucial to understand how taxes impact labor income inequalities. Further, although tax incentives target mid- and low-wage workers, the surplus generated by the policy does not "trickle down" to low-wage workers. Compared to tax cuts, tax credits allow policymakers to create a link between tax benefits and desired outcomes. Yet, as demonstrated in this setting, this link can be muted as statutory incidence does not necessarily coincide with economic incidence: the tax credit incidence does not benefit low-wage workers but instead spills over to workers less likely to be eligible.

By gender. We then look at the heterogeneity in wage gains by gender. Table 4 reports difference in differences estimates of the impact of the tax credit on gross hourly wages of men and women. Overall, we find that women benefit from slightly smaller wage gains than men. Incidence estimates are far less contrasted than for skill groups, and women might have jobs requiring less skills.

By incumbency status. Kline et al. (2019) study how profit windfalls generated by patents translate into worker compensation. They show that incumbent employees benefit from higher wages, while entrants do not. They rationalize their findings as 
Figure 7: Heterogeneity across Skill Groups: Event Study Estimates

(a) High-skill workers

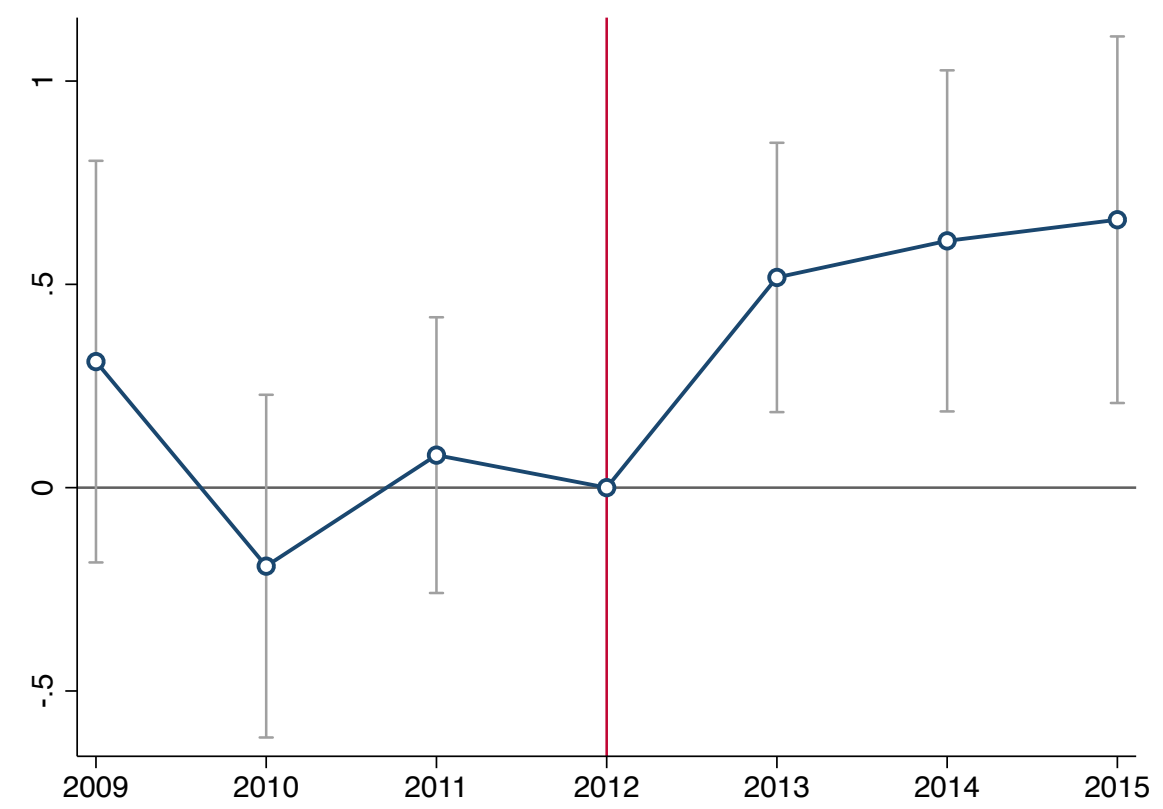

Notes: This figure reports the estimated impact of the CICE tax credit on wages of high-skill workers. Other notes as in Figure 5.

(b) Low-skill workers

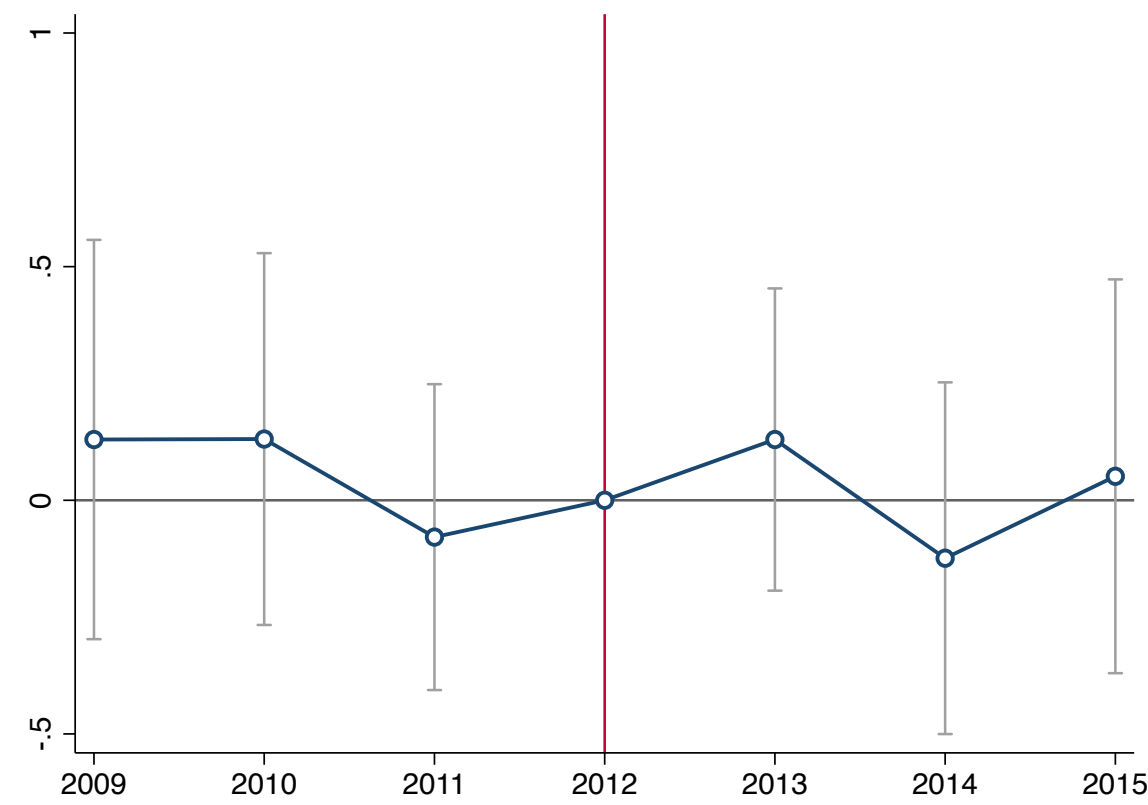

Notes: This figure reports the estimated impact of the CICE tax credit on wages of low-skill workers. Other notes as in Figure 5. 
Table 4: Heterogeneity across Genders: Difference in Differences Estimates

\begin{tabular}{lccccccc}
\hline \hline & \multicolumn{3}{c}{ Mean gross hourly wage, weighted by hours worked (log) } \\
\cline { 2 - 4 } \cline { 7 - 8 }$Z_{i} \times \mathbb{1}\{t \geq 2013\}$ & \multicolumn{3}{c}{ Women } & \multicolumn{4}{c}{ Men } \\
\cline { 2 - 4 } \cline { 6 - 8 } & $0.267^{* * *}$ & $0.306^{* * *}$ & $0.425^{* *}$ & & $0.392^{* * *}$ & $0.479^{* * *}$ & $0.440^{* * *}$ \\
& $(0.0897)$ & $(0.110)$ & $(0.166)$ & & $(0.0859)$ & $(0.108)$ & $(0.153)$ \\
\hline Observations & 660,873 & 115,449 & 28,330 & & 687,655 & 123,736 & 31,465 \\
$R^{2}$ & 0.886 & 0.859 & 0.856 & & 0.919 & 0.848 & 0.796 \\
Window & $(2.2,2.8)$ & $(2.2,2.8)$ & $(2.2,2.8)$ & & $(2.2,2.8)$ & $(2.2,2.8)$ & $(2.2,2.8)$ \\
Bin width & $3.33 \mathrm{pp}$ & $3.33 \mathrm{pp}$ & $3.33 \mathrm{pp}$ & & $3.33 \mathrm{pp}$ & $3.33 \mathrm{pp}$ & $3.33 \mathrm{pp}$ \\
Sample & $>0 \%$ & $>30 \%$ & $>50 \%$ & & $>0 \%$ & $>30 \%$ & $>50 \%$ \\
Lagged controls & $Y e s$ & $Y e s$ & Yes & & Yes & Yes & Yes \\
\hline \hline
\end{tabular}

Notes: This table reports the estimated impact of the CICE tax credit on wages of workers by gender. Other notes as in Table 3.

follows: the less incumbent workers are substitutable with new entrants, the more they extract rents from the firm in the form of wage premia. To test whether this hypothesis could apply in our setting, we divide workers into two groups, one of "incumbents" and one of "entrants". We define "incumbents" as workers with a permanent contract who were working in the same firm the previous year. Other workers are labelled "entrants".

Table 5 reports difference in differences estimates of the impact of the tax credit on gross hourly wages of incumbents and entrants. The positive effects of the policy load on incumbent employees. An increase in the predicted effective tax credit rate by 1 percentage point translates into a $0.65 \%$ increase in gross hourly wage of incumbent workers. Coefficients reported in Table A10 show that among incumbents, high-skill

Table 5: Heterogeneity between Entrants and Incumbents: Difference in Differences Estimates

\begin{tabular}{lccccccc}
\hline \hline & \multicolumn{3}{c}{ Mean gross hourly wage, weighted by hours worked (log) } \\
\cline { 2 - 4 } \cline { 7 - 9 }$Z_{i} \times \mathbb{1}\{t \geq 2013\}$ & -0.0736 & 0.0691 & -0.0752 & & $0.431^{* * *}$ & $0.486^{* * *}$ & $0.647^{* * *}$ \\
& $(0.155)$ & $(0.196)$ & $(0.300)$ & & $(0.0687)$ & $(0.0854)$ & $(0.124)$ \\
\hline Observations & 665,922 & 99,010 & 23,379 & & 679,082 & 129,296 & 34,456 \\
$R^{2}$ & 0.525 & 0.643 & 0.634 & & 0.925 & 0.845 & 0.760 \\
Window & $(2.2,2.8)$ & $(2.2,2.8)$ & $(2.2,2.8)$ & & $(2.2,2.8)$ & $(2.2,2.8)$ & $(2.2,2.8)$ \\
Bin width & $3.33 p p$ & $3.33 p p$ & $3.33 p p$ & & $3.33 p p$ & $3.33 p p$ & $3.33 p p$ \\
Sample & $>0 \%$ & $>30 \%$ & $>50 \%$ & & $>0 \%$ & $>30 \%$ & $>50 \%$ \\
Lagged controls & $Y e s$ & $Y e s$ & Yes & & Yes & Yes & Yes \\
\hline \hline
\end{tabular}

Notes: This table reports the estimated impact of the CICE tax credit on wages of incumbents and entrants. Other notes as in Table 3. 
workers only benefit from wage gains. Finally, results in Table A11 show that among incumbent employees, men benefit from higer wage gains than women. Overall, the profit windfalls generated by the CICE have distributive effects similar to that of profit windfalls studied in Kline et al. (2019) ${ }^{30}$ and Howell and Brown (2019). This set of results suggests that the mechanisms underlying the wage pass-through might not be specific to the population of firms studied, or the type of policy generating the surplus.

\subsection{Mechanisms}

Our results so far show that the policy had sizable effects on workers wages, but only on those of high-skill workers. To understand the underlying mechanisms driving this contrasted wage incidence, we now explore other firm-level effects of the tax credit.

We test for several mechanisms that may be at play. First, because the policy decreases the marginal cost of production, firms might increase the scale of their production and, to do so, hire more. Firms whose production function requires many low-skill workers will benefit more from the policy, and might in turn want to hire more of these workers. It would thus result in more employment in general, and for low-skill workers in particular. Next, when the policy was introduced, the net-of-tax credit gross wage of eligible workers decreased. In standard competitive labor market models where labor demand is more elastic than labor supply, the demand for eligible workers rapidly increases, which bids up their wages, until the labor costs of eligible and non-eligible workers are equalized. If the labor supply of low-skill workers is more elastic, the demand shock might translate into higher employment, rather than higher wages. Additionally, if employment effects are different across skill groups, the marginal productivity of workers in the two groups will also adjust. Assuming complementary between the two skill groups, an increase in the number of low-skill workers will raise the productivity of high-skill workers. As a result, the wage of non-eligible workers will be impacted by the tax reform.

Table 6 reports the results of the estimation of Equation 2 using employment as dependent variable. We measure employment as the number of contracts in each firm. Figure 8 shows the result of the estimation of equation 3 with employment as the dependent variable. We find no employment effect. Table A12 and Figure A6 present similar estimates with sales as dependent variables. Coefficients are all close to zero and non significant. Although the policy lowers production costs, firms did not expand.

Table 7 reports the results of the estimation of Equation 2 using employment by skill group as separate dependent variables. Estimated coefficients are all close to zero and not statistically significant for both groups. The skill composition of workers has

\footnotetext{
${ }^{30}$ They find that incumbent workers captured 61 cents of every dollar of patent-induced surplus
} 
not changed. Differential incidence by skill group is therefore unlikely to be driven by skill complementarity.

Figure 8: Effects on Employment: Event Study Estimates

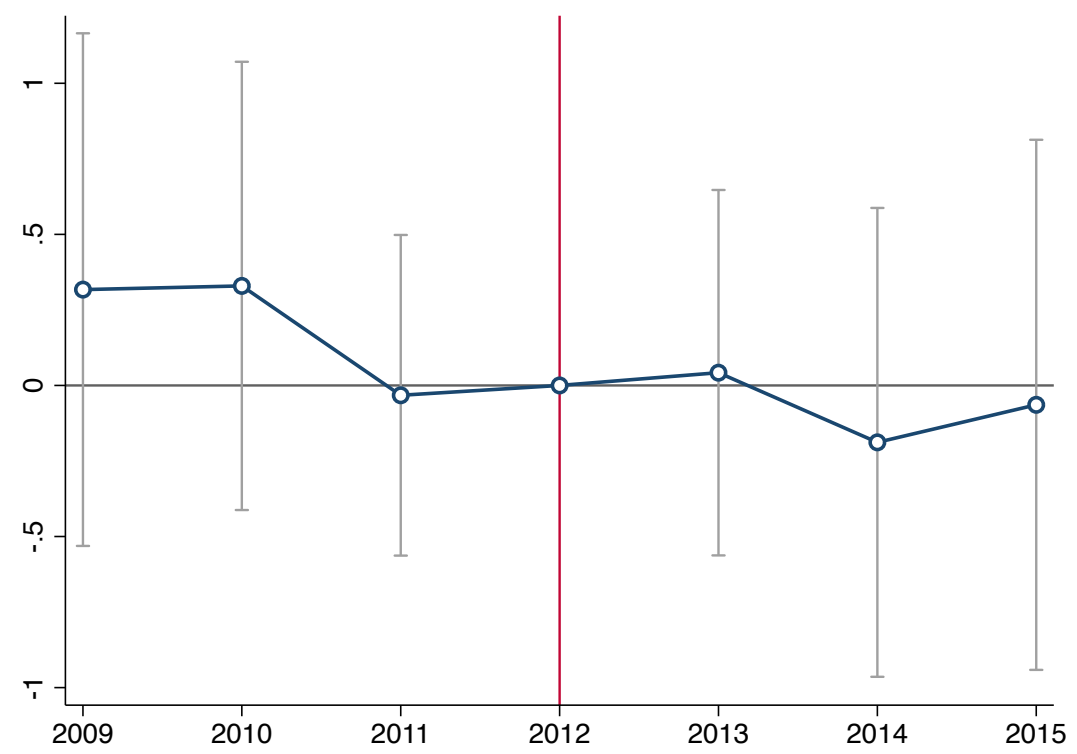

Notes: This figure plots the point estimates and 95-percent confidence intervals from the event study regression defined in Equation 3. The unit of observation is the firm. The dependent variable is the log of the number of full time equivalents. The independent variable is the 2012 payroll share of workers earning less than $2.5 \mathrm{MW}$ multiplied by the tax credit rate and interacted with year dummies. 2012 is the reference year. The sample includes firms with at least $50 \%$ of their payroll paid to workers earning between 2.2 and 2.8 MW. Bins are defined as in Table 2. Lagged controls are included. Robust standard errors are clustered at the firm level.

Firms did not use the surplus generated by the policy to increase employment. ${ }^{31}$ Potential explanations include the presence of fixed costs in recruiting and training new hires, high firing costs as well as uncertainty about the continuation of the policy. Due to the fixed hiring costs, firms could choose not to adjust their labor force even when labor costs decrease (Bentolila and Saint-Paul, 1994). ${ }^{32}$ Policy uncertainty regarding the continuation of the tax credit might have expanded their zone of inaction, in particular in the presence of high firing costs (Kramarz and Michaud, 2010). The macroeconomic environment was also unfavorable which might have discouraged firms from hiring despite reduction in the effective labor cost. Additionally, because the policy is a corporate income tax credit, it might have lowered labor costs less saliently than payroll tax cuts. ${ }^{33}$

\footnotetext{
${ }^{31}$ In line with this result, Fuest et al. (2018) find that higher corporate income taxe rates do not lead to higher unemployment.

${ }^{32}$ For instance, Kline et al. (2019) estimate that the replacement cost of an incumbent worker roughly amounts to a new hire's annual earnings.

${ }^{33}$ Anecdotal evidence provided by Carbonnier et al. (2016) lends support to this view. Interviews with accounting and human resources staff highlighted asymmetries of information about the tax credit
} 


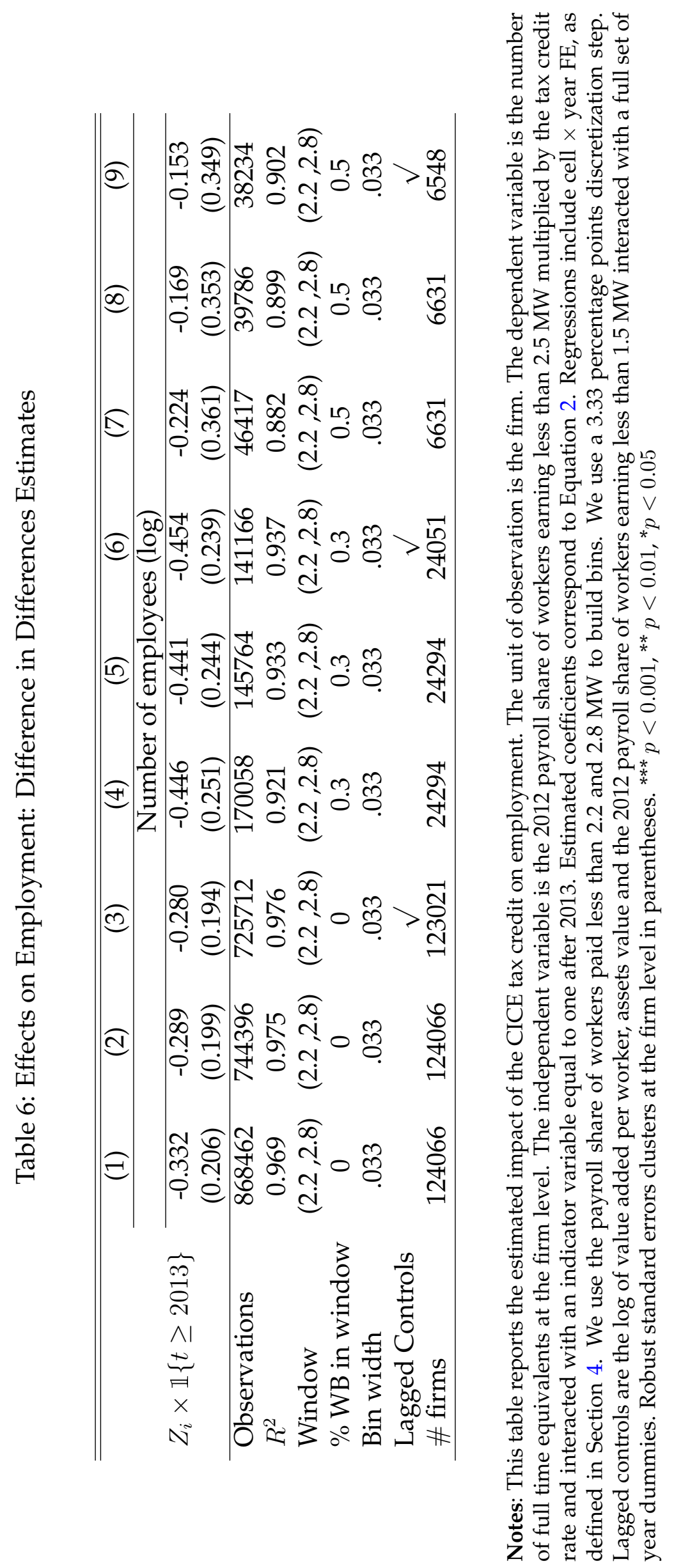


Table 7: Effect on Employment by Skill Group: Difference in Differences Estimates

\begin{tabular}{|c|c|c|c|c|c|c|}
\hline \multirow{4}{*}{$Z_{i} \times \mathbb{1}\{t \geq 2013\}$} & \multicolumn{6}{|c|}{ Number of employees (log) } \\
\hline & \multicolumn{3}{|c|}{ low-skill workers } & \multicolumn{3}{|c|}{ High-skill workers } \\
\hline & -0.395 & -0.395 & -0.333 & 0.160 & 0.130 & -0.0730 \\
\hline & $(0.229)$ & $(0.282)$ & $(0.407)$ & $(0.252)$ & $(0.296)$ & $(0.407)$ \\
\hline Observations & 696,687 & 126,374 & 31,982 & 604,590 & 107,049 & 27,178 \\
\hline$R^{2}$ & 0.888 & 0.870 & 0.869 & 0.866 & 0.826 & 0.765 \\
\hline Window & $(2.2,2.8)$ & $(2.2,2.8)$ & $(2.2,2.8)$ & $(2.2,2.8)$ & $(2.2,2.8)$ & $(2.2,2.8)$ \\
\hline Bin width & $3.33 p p$ & 3.33pp & $3.33 p p$ & $3.33 p p$ & 3.33pp & $3.33 p p$ \\
\hline Sample & $>0 \%$ & $>30 \%$ & $>50 \%$ & $>0 \%$ & $>30 \%$ & $>50 \%$ \\
\hline Lagged controls & Yes & Yes & Yes & Yes & Yes & Yes \\
\hline
\end{tabular}

Notes: This table reports the estimated impact of the CICE tax credit on employment by skill groups. The unit of observation is the firm. The dependent variable is the number of full time equivalents. The independent variable is the 2012 payroll share of workers earning less than $2.5 \mathrm{MW}$ multiplied by the tax credit rate and interacted with an indicator variable equal to one after 2013. Other notes as in Table 6.

Overall, the policy targeting does not seem relevant to explain how the gains are distributed as the policy surplus spills over onto ineligible workers. Standard labor market mechanisms, such as scale effects or complementarity between skill groups, do not seem to be driving these effects.

\section{Incidence at the employee-level}

An important feature of tax credits is that they lower the tax bill only for a set of firms based on their activity or characteristics. The policy studied here is targeted at workers paid less than $2.5 \mathrm{MW}$, which entails a notch in the net-of-tax credit labor cost of workers. In this section we investigate whether policy targeting is able to shape the distributive effects of tax incentives on wages. We study whether workers' individual eligibility to the tax credit impacts wages.

\subsection{Standard wage posting model}

In a standard wage posting model (e.g. Manning, 2003), firms with given levels of productivity $p$ face a trade-off when posting wage $w$. To maximize the expected profit associated with a vacancy, firms strike a balance between increasing the probability that a vacancy is filled by offering a higher wage $w$ on the one hand, or the vacancy

benefit. Many firms contract out accounting, which reduced the salience of the policy for people in charge of recruitment. Some business owners had not anticipated how much they would gain from the tax credit the first time they benefited it. Refer to page 181, E.1.52 Expert-comptable, PACA (in French). 
surplus in case it is filled $(p-w)$ by offering a lower wage on the other hand. As a result, the expected profit is concave in $w$ for a given $p$.

In a pre-reform equilibrium where reservation wages and productivity types are continuously distributed, optimal posted wages $w^{*}(p)$ are continuous. The policy introduces a notch in the net-of-tax credit profitability of a vacancy $p-w \cdot(1-\tau$. $\left.\mathbb{1}_{(w<2.5 M W)}\right)$, with no direct impact on the probability that it is filled. A firm whose optimal posted wage is just below the eligibility cut-off benefits from a profit windfall and has no incentive to change its posted wage. A firm whose productivity is just slightly higher and whose optimal posted wage is just above the eligibility cutoff has an incentive to post a wage just below the eligibility cut-off as doing so only marginally decreases the probability the vacancy is filled while generating first order gains in profitability. As a result, the distribution of wages should exhibit an excess mass to the left of the cut-off and a missing mass to its right (Kleven and Waseem, 2013). ${ }^{34}$

\subsection{Effects on wages}

A graphical and transparent way to test whether firms change their wage setting behaviors after the reform is to study the distribution of wages around the eligibility cutoff. An excess bunching and hole pattern would indicate that firms respond to the tax incentive created by the discontinuity in individual eligibility of workers. Conversely, an absence of deformation in the distribution of gross wage earnings would indicate that the payoff of each employer-employee match is discontinuous. The wage incidence documented at the firm-level would not be driven by worker-level responses, but would instead reflect a collective incidence that cannot be evidenced at the individual level.

Graphical evidence. Figure 9 depicts the distribution of gross hourly wage earnings around the eligibility cut-off for different time periods. We consider two periods: 2009-2012 is the pre-reform period and 2013-2015 is the period after the reform. The solid black vertical line depicts the wage eligibility threshold. Figure 9a plots the distribution of wages for all employees of firms included in the estimation sample. By construction, all employees work in firms that claimed the tax credit. Figure $9 \mathrm{~b}$ includes only new hires, defined as workers starting a new job in a new firm during the year. Figure 9a shows that the distribution of wages is very smooth around the eligibility threshold both before and after the reform. No excess bunching and hole pattern is visible. We test for discontinuity in the distribution at the cut-off after the reform

\footnotetext{
${ }^{34}$ We provide a formal description of the model and a characterization of the bunching region in Appendix OA1.
} 
using a McCrary test (McCrary, 2008) and find no statistically significant discontinuity (coefficient $=0.0044$, s.e. $=0.0046$ ).

A potential explanation for this absence of behavioral response is that firms might face constraints when setting wages. For instance, downward nominal wage rigidities may prevent employers from decreasing workers' wage as desired. To test this hypothesis, we restrict our sample to new hires. Figure $9 \mathrm{~b}$ plots the distribution of gross hourly wage earnings of newly-hired workers, and even this subsample displays no excess mass and hole pattern. A McCrary test yields no significant discontinuity estimate (coefficient $=-0.0021$, s.e. $=0.012$ ).

These findings imply that the net-of-tax credit labor cost and the profit derived from these employer-employee matches are discontinuous at the cut-off. Workers on both sides of the threshold are likely perfect substitutes, and yet entail different costs for firms. ${ }^{35}$

Estimation. We formally test for the presence of bunching using methods developed by Saez (2010); Chetty et al. (2011) and Kleven and Waseem (2013). To detect the excess or missing masses in the distribution of wages around the eligibility threshold, we first estimate a counterfactual wage distribution. The counterfactual distribution is fitted using a seventh degree polynomial excluding observations in a range $\left[w_{L}, w^{N}\right]$ while taking into account that any excess mass in the excluding range to the left of the notch has to be compensated for to the right of the notch. We test the robustness of our results to several exclusion ranges. Excess bunching is estimated as the difference between the counterfactual and observed distributions in the excluding range.

More formally, we estimate the sum of total extra bunching $\hat{B}_{N}$ in the range $\left[w_{L}, w^{N}\right]$ as follows:

$$
\hat{B}_{N}=\sum_{i=w_{L}}^{w^{N}} C_{i}-\hat{C}_{i}
$$

where $C_{i}$ is the number of observations in wage bin $i$ and $\hat{C}_{i}$ is the counterfactual number of observations in the same bin. Standard errors are calculated using a bootstrap procedure.

We then estimate $\hat{b}$, the rate of extra bunching in the range $\left[w_{L}, w^{N}\right]$.

$$
\hat{b}=\frac{\hat{B}_{N}}{\frac{1}{w^{N}-w_{L}+1} \sum_{i=w_{L}}^{w^{N}} \hat{C}_{i}}
$$

A significantly positive $\hat{b}$ would indicate an excess mass of employees paid just below $2.5 \mathrm{MW}$.

\footnotetext{
${ }^{35}$ The net-of-tax credit labor cost difference is equal to 1,040 euros, as computed using using the $6 \%$ tax credit rate applicable in 2014 and 2015.
} 
Figure 9: The Effect of Individual Eligibility on Gross Wages

(a) All Employees

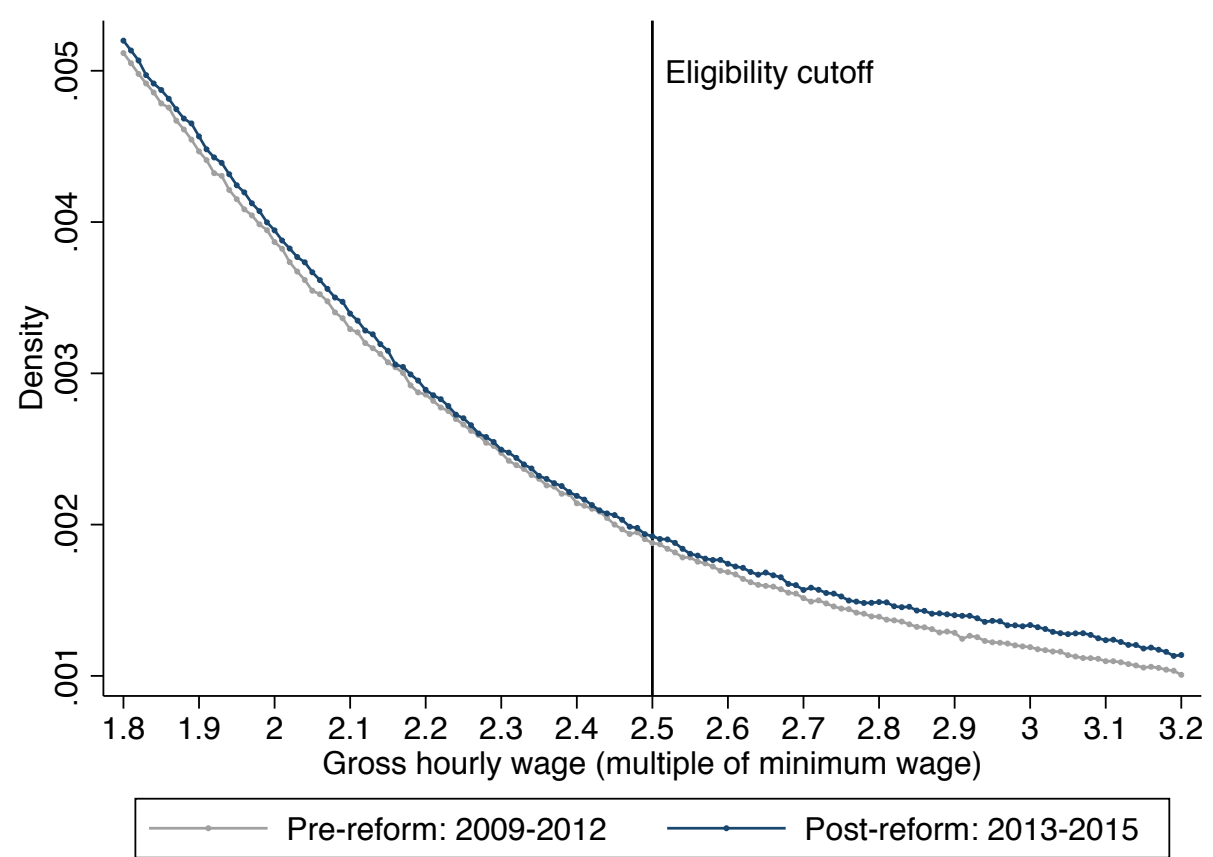

(b) New hires

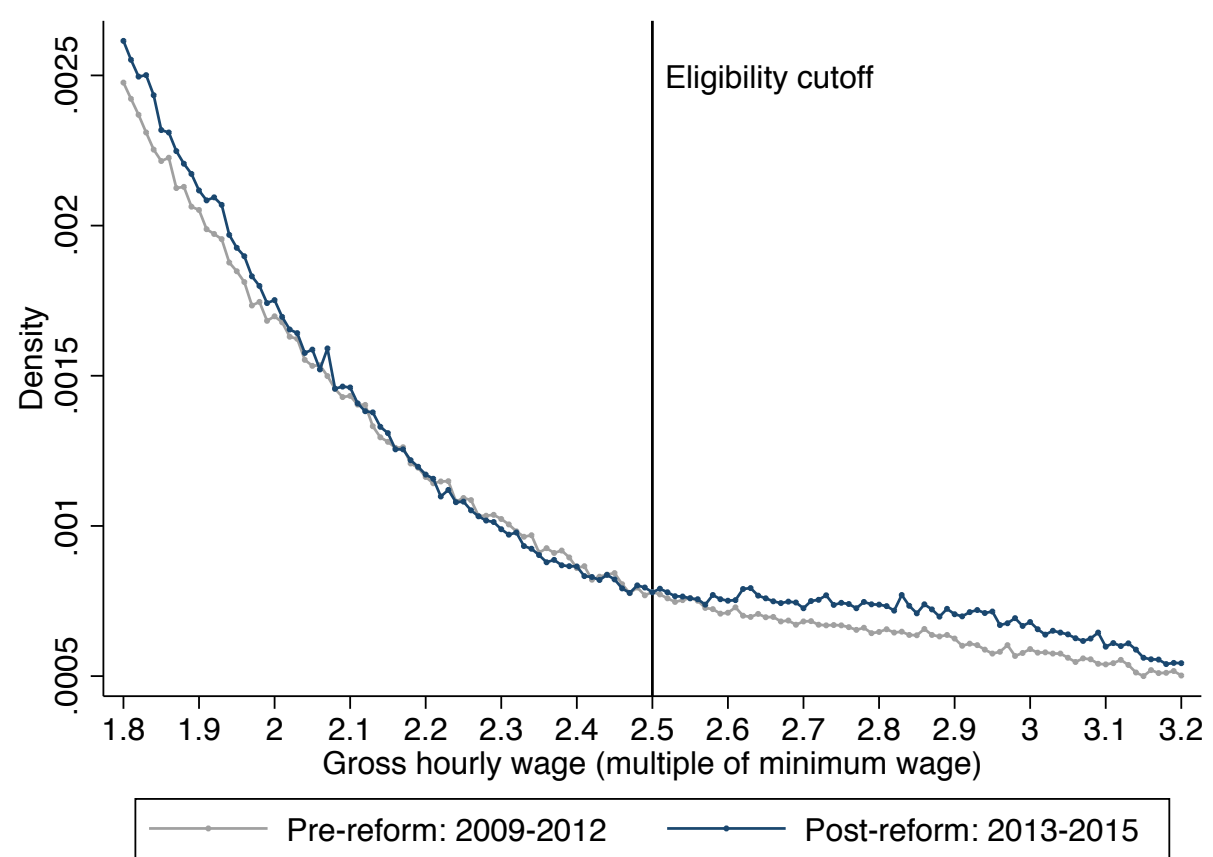

Notes: This figure depicts the distribution of gross hourly wages expressed as multiples of the minimum wage in France for years before the reform (2009-2012) and years after the reform (2013-2015). The vertical solid line depicts the wage threshold under which workers open rights to the tax credit. The sample includes all employees (Panel a) in firms included in the firm-level estimation sample. The sample is restricted to new hires in Panel $b$. New hires are workers starting a new job in a new firm during the year. 
Table 8: Bunching estimation

\begin{tabular}{|c|c|c|c|c|}
\hline \multirow[b]{2}{*}[\mathbf{w}_{\mathbf{L}},\mathbf{w}^{\mathbf{N}}]{} & \multicolumn{2}{|c|}{ All } & \multicolumn{2}{|c|}{ New Hires } \\
\hline & Pre-reform & Post-reform & Pre-reform & Post-reform \\
\hline$[2.45,2.50]$ & $\begin{array}{c}-0.037 \\
(0.0191)\end{array}$ & $\begin{array}{l}-0.0075 \\
(0.0195)\end{array}$ & $\begin{array}{c}0.0088 \\
(0.0810)\end{array}$ & $\begin{array}{c}0.0167 \\
(0.1473)\end{array}$ \\
\hline$[2.40,2.50]$ & $\begin{array}{c}-0.0194 \\
(0.0254)\end{array}$ & $\begin{array}{l}-0.0029 \\
(0.0287)\end{array}$ & $\begin{array}{l}-0.0895 \\
(0.1174)\end{array}$ & $\begin{array}{l}-0.0358 \\
(0.2146)\end{array}$ \\
\hline$[2.35,2.50]$ & $\begin{array}{c}-0.0053 \\
(0.0327)\end{array}$ & $\begin{array}{l}-0.0047 \\
(0.0342)\end{array}$ & $\begin{array}{c}-0.1622 \\
(0.1485)\end{array}$ & $\begin{array}{c}-0.2454 \\
(0.2637)\end{array}$ \\
\hline$[2.30,2.50]$ & $\begin{array}{c}-0.0193 \\
(0.0385)\end{array}$ & $\begin{array}{l}-0.0127 \\
(0.0406)\end{array}$ & $\begin{array}{c}-0.2205 \\
(0.1741)\end{array}$ & $\begin{array}{c}-0.4631 \\
(0.3055)\end{array}$ \\
\hline
\end{tabular}

Notes: New hires are defined as workers starting a new contract in a new firm during the year. The sample only includes employees working in firms that claimed the tax credit and that are in our firmlevel estimation sample. ${ }^{*}: \mathrm{p}<0.05 ;{ }^{* *}: \mathrm{p}<0.01 ;{ }^{* * *}: \mathrm{p}<0.001$.

Results. Table 8 reports the estimated rate of excess bunching in employees' wage distribution for different estimation ranges. Estimates are all close to zero and not statistically significant, both in the pre- and post-reform years.

\subsection{Effects on wage growth}

In this section, we explore another margin of response: wage growth. Employers might be reluctant to increase the wages of workers just below the eligibility cut-off to keep benefiting from the tax credit. They may also not want to increase wages just above the threshold as its nominal level increases annually along with the nominal minimum wage. As a result, wage growth of employees close to the cut-off might be locally lower.

Graphical evidence. Figure 10 depicts the mean year-on-year wage growth of continuing workers for bins of past year's wage for two time periods: before the reform (2009-2012) and after the reform (2013-2015). Wage growth rates are centered on the period mean growth rate in the considered interval. Continuing workers are workers with a permanent contract who had the same job in the same firm the year before. ${ }^{36}$ Wage growth does not appear slower for workers close to the eligibility cut-off. The shape of the two curves are very similar for both periods, especially around the threshold.

\footnotetext{
${ }^{36}$ We exclude fixed term contract because by law employers are required to give them an end-of-term bonus that amounts to $10 \%$ of the total gross wage earned during the time of that contract.
} 
Figure 10: Distribution of wage growth of continuing employees

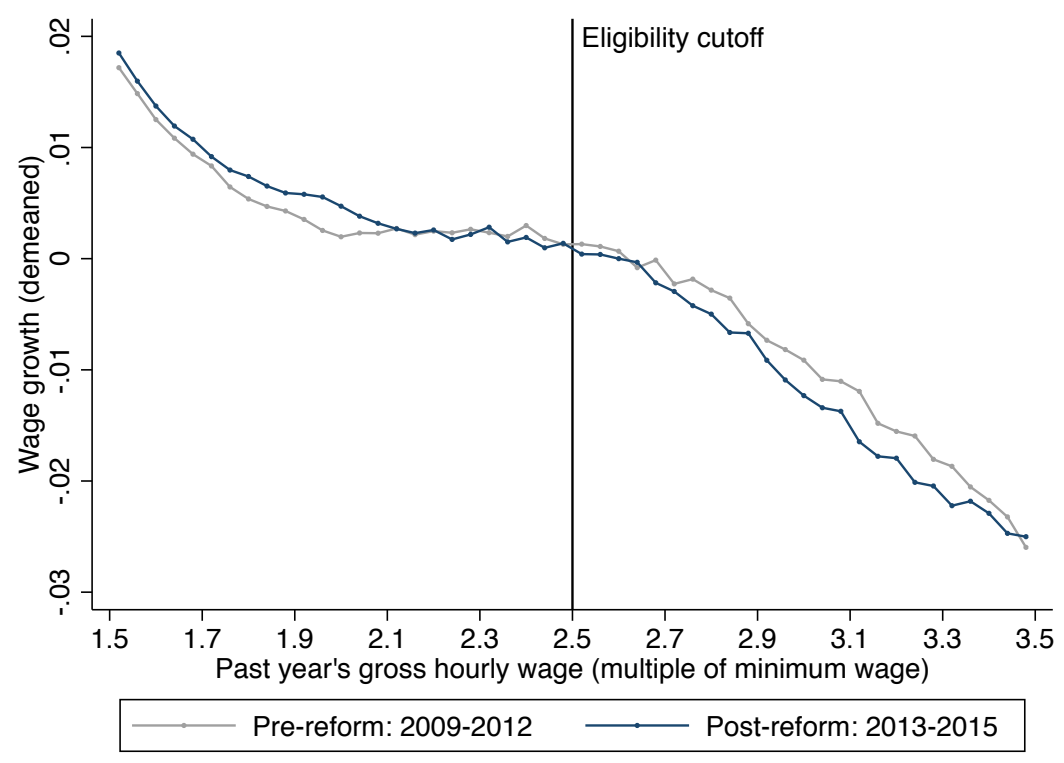

Notes: This figure depicts the relationship between the year-on-year wage growth rate and past year's wage for two time periods, before and after the reform. Wages are expressed in multiples of the minimum wage. Wage growth is centered on the period's mean wage growth in the [1.5 MW, 3.5 MW] wage range.

Estimation. We formally test for local distortions in wage growth. Excluding a range of observations around the notch, we estimate a counterfactual relationship between wage growth and past wage. We then compare the counterfactual wage growth to the observed wage growth. We provide a detailed description of our estimation procedure in Section A9. Table A13 reports estimation results for several excluded ranges. Point estimates are the difference between the observed and the counterfactual wage growths in the excluded range for different time periods: before and after the reform. All coefficients are close to zero, none is statistically significant.

Overall, we uncover no wage setting response to individual eligibility is unlikely. As wage growth is almost always positive, this absence of reaction is unlikely to be driven by downward wage rigidity. The implication of our findings is that the net-oftax credit labor cost of otherwise similar employees is persistently different after the policy is implemented.

\section{Discussion}

We study a large corporate income tax credit and evidence that it had a substantial firm-level incidence on wage earnings. About $50 \%$ of the surplus is passed on to workers through higher wages. On average, therefore, lower taxes increase wage earnings. 
Worker-level mechanisms. Yet, we show that employers do not change their wage setting behavior in response to the individual eligibility status of their employees. After the reform, a sizable net-of-tax credit labor cost differential persists between otherwise similar workers, which cannot be rationalized by standard tax incidence frameworks modelling a competitive labor market. ${ }^{37}$ The sizable wage incidence uncovered at the firm-level is thus not explained by employee-level mechanisms. This finding is policy relevant as it implies that employee-level policy targeting does not determine which workers will ultimately benefit from tax incentives. It is also methodologically relevant. Given that firms' responses are not driven by individual level mechanisms, using employee-level identification strategies only may lead to conclude to an absence of wage incidence.

Why is there no employee-level response? We explore the role of labor market institutions and fairness norms. First, firms may not be able to set wages as desired due to labor market institutions such as industry-level collective wage agreements. Yet, these agreements are not the leading explanation for this absence of behavioral response. Although they cover a large share of workers in France (OECD, 2012), these agreements are not binding and firms retain flexibility in setting wages. Goux and Maurin (1999) documents large within sector-occupation wage dispersion. Verdugo (2016) find little evidence of downward nominal wage rigidity in the aftermath of the 2008 recession in France. The absence of bunching in the distribution of new hires wages additionally indicates that wage rigidities cannot explain why firms do not adjust wages. Next, Saez et al. (2012) and Saez et al. (2019) argue that the absence of individual response is due to fairness norms. In the presence of relative wage concerns among coworkers, granting lower wage growth to some employees because of the policy might be seen as unfair and could cut workers morale and result in drop out (Dube et al., 2015). This explanation does not seem the most fit for our setting, as eligibility is not determined by immutable workers characteristics such as age or birth date. Instead, it is defined by the wage rate and workers could arguably be indifferent between being paid exactly $2.5 \mathrm{MW}$ and being paid a few cents more. If so, on the margin, firms could easily set wages such that new hires are just eligible.

Overall, employee-level mechanisms do not seem to account for the wage incidence of the tax credit measured at the firm level. Wage setting rigidities or norms do not fully this absence of employee-level response. Rather, incidence is collective and seems driven by firm-level mechanisms.

\footnotetext{
${ }^{37}$ It is consistent with other papers concluding to the absence of incidence at the employee level (Alvaredo et al., 2017; Bozio et al., 2017a; Bosch and Micevska-Scharf, 2017). It also relates to Saez et al. (2019) who study payroll tax cuts targeted at young workers and show that incidence is not driven by the individual eligibility status as firms most exposed to the policy also increased the wages of older workers.
} 
Firm-level mechanisms. We show that wage incidence is not uniform across groups of workers. We find that the policy only increases the wages of high-skill workers, not those of low-skill workers even though they are nearly all individually eligible to the tax credit. In other words, the policy benefits do not "trickle down" to low-wage workers. These results suggest that within-firm, the occupation of employees matters to understand whether they will ultimately benefit from tax incentives. Our results do not appear to be driven by scale effects or skill complementarity as employment for both skill groups is flat.

Instead, our results suggest that the surplus generated by the tax reform is shared collectively at the firm level between employers and groups of employees. Surplus sharing has been shown to be a relevant mechanism in other settings where firms enjoy a profit windfall. For instance, Kline et al. (2019) show that the surplus generated by patents translates in higher wages for some workers, thus increasing within-firm earnings inequality. Wage gains are concentrated among workers in the top quartile of the within-firm wage distribtution and among employees at the top of the firm's hierarchy. In line with their results, we find that wage gains load on skilled incumbent employees. They also propose that firms use the surplus to increase the wage of workers who would be the most costly to replace in case they quit.

To test the retention mechanism, we look at the impact of the policy on the retention rate of workers by skill group. The retention rate is defined as the share of continuing employees with a permanent contract who are still working in the same firm in December. Table 9 reports estimation results corresponding to Equation 2. Figures A7 and A8 depict corresponding event studies. We find a statistically significant effect of the tax credit on the retention rate of high-skill workers. An increase in the predicted effective tax credit rate by 1 percentage point translates into a .55 percentage point increase in the retention rate of high-skill workers. The policy had no effect on the retention of low-skill employees. This pattern parallels the heterogeneity of wage gains across skill groups, suggesting employers increase the wages to retain workers costly to replace.

The heterogeneous incidence by skill groups that we document complements the findings of Fuest et al. (2018) who study negative profit shocks. They find that increases in local corporate income tax rates decrease workers wages on average, but impact relatively less those of high-skill workers. It suggests the wage incidence of profit shocks might be asymmetric: high-skill workers benefit relatively more from profit windfalls, and suffer less from tax increases. An interesting venue for further research would be to understand whether this asymmetry is driven by firms' willingness to retain workers who are the most costly to replace.

Additionnally, recent research (Caldwell and Danieli, 2018) has emphasized the separate roles of outside options and of employer-specific surpluses in determining 
Table 9: Impact on Workers Retention Rate across Skill Groups

\begin{tabular}{lccccccc}
\hline \hline & \multicolumn{3}{c}{ Retention rate of permanent contract workers } \\
\cline { 2 - 4 } \cline { 6 - 8 }$Z_{i} \times \mathbb{1}\{t \geq 2013\}$ & \multicolumn{3}{c}{ Low-skill } & & \multicolumn{3}{c}{ High-skill } \\
\cline { 2 - 4 } \cline { 6 - 8 } & -0.0432 & 0.0786 & -0.158 & & $0.433^{* * *}$ & $0.453^{* * *}$ & $0.547^{* * *}$ \\
& $(0.112)$ & $(0.145)$ & $(0.215)$ & & $(0.122)$ & $(0.147)$ & $(0.201)$ \\
\hline Observations & 636,565 & 108,338 & 26,118 & & 547,917 & 94,763 & 23,722 \\
$R^{2}$ & 0.476 & 0.410 & 0.414 & & 0.444 & 0.434 & 0.431 \\
Window & $(2.2,2.8)$ & $(2.2,2.8)$ & $(2.2,2.8)$ & & $(2.2,2.8)$ & $(2.2,2.8)$ & $(2.2,2.8)$ \\
Bin width & $3.33 \mathrm{pp}$ & $3.33 \mathrm{pp}$ & $3.33 \mathrm{pp}$ & & $3.33 \mathrm{pp}$ & $3.33 \mathrm{pp}$ & $3.33 \mathrm{pp}$ \\
Sample & $>0 \%$ & $>30 \%$ & $>50 \%$ & & $>0 \%$ & $>30 \%$ & $>50 \%$ \\
Lagged controls & Yes & Yes & Yes & & Yes & Yes & Yes \\
\hline \hline
\end{tabular}

Notes: This table reports the estimated impact of the CICE tax credit on the retention rate of employees, by skill group. The retention rate is the share of employees with a permanent contract who were working in the firm the previous year and are working in the same firm in December. Other notes as in Table 3.

workers' wages. While Fuest et al. (2018) use changes in local taxes impacting both firms' profitability and workers' local outside options, we study profitability shocks that are likely orthogonal to workers' outside options. Further research might consider teasing out the impact of tax reforms on wages through changes in workers' outside options and through changes in firms' profitability, and whether it differs across skill groups.

\section{Conclusion}

This paper has shown that firms play a crucial role in shaping labor market inequalities. We find that a profit windfall generated by a far reaching corporate income tax credit translated in substantial wage gains for workers. It supports the idea that idiosyncratic shocks to firms' profits are an important determinant of worker pay.

We also show that profit windfall not only increase wage inequalities across firms, but also within firms. The wage pass through of the tax credit is markedly heterogeneous across workers. We find that only incumbent high-skill workers benefit from higher wages. The benefits generated by the reform do not trickle down to low wage workers or entrants. Instead, employers seem to raise the wages of workers who are the most costly to replace. We document that the policy increased the retention rate of high-skill workers, not of low-skill workers.

We find that fiscal incentives strongly affect the wage setting behavior of employers; yet irrespective of the policy targeting. We find no bunching in the wage distribution of employees near the eligibility wage cut-off and low-skill workers, who are almost all individually eligible, get no wage gains. Compared to tax cuts, tax credits al- 
low policymakers to link a tax expenditure to a given behavior, potentially generating efficiency gains. However, employers seem to distribute the surplus generated by the tax credit as they would with other profit surpluses, regardless of the employee-level incentive embedded in the design of the tax credit.

\section{References}

Alvaredo, F., Breda, T., Roantree, B. and Saez, E. (2017). Contribution ceilings and the incidence of payroll taxes. De Economist, 165 (2), 129-140.

Anderson, P. M. and MEYER, B. D. (1997). The effects of firm specific taxes and government mandates with an application to the us unemployment insurance program. Journal of Public Economics, 65 (2), 119-145.

Arulampalam, W., Devereux, M. P. and Maffini, G. (2012). The direct incidence of corporate income tax on wages. European Economic Review, 56 (6), 1038-1054.

AuERBACH, A. J. (2018). Measuring the effects of corporate tax cuts. Journal of Economic Perspectives, 32 (4), 97-120.

Auten, G. and CARroll, R. (1999). The effect of income taxes on household income. The Review of Economics and Statistics, 81 (4), 681-693.

AzÉmAr, C. and Hubbard, R. G. (2015). Country characteristics and the incidence of capital income taxation on wages: An empirical assessment. Canadian Journal of Economics, 48 (5), 1762-1802.

Bentolila, S. and SAint-Paul, G. (1994). A model of labor demand with linear adjustment costs. Labour Economics, 1 (3-4), 303-326.

BOSCH, N. and MicEVSKA-SCHARF, M. (2017). Who bears the burden of social security contributions in the netherlands? evidence from dutch administrative data. De Economist, 165 (2), 205-224.

Bozio, A., BREDA, T. and GRENET, J. (2017a). Incidence and behavioural response to social security contributions: An analysis of kink points in france. De Economist, 165 (2), 141-163.

- - - and - (2017b). Incidence of social security contributions: evidence from France. Tech. rep., Working paper.

CAldwell, S. and DANieli, O. (2018). Outside options in the labor market. Unpublished manuscript. 
Caliendo, L., Monte, F. and Rossi-HansberG, E. (2015). The anatomy of french production hierarchies. Journal of Political Economy, 123 (4), 809-852.

Carbonnier, C., Fredon, S., Gauthier, B., Rot, G., Malgouyres, C., Mayer, T., Py, L. and URVOY, C. (2016). Evaluation interdisciplinaire des impacts du CICE en matière de compétitivité internationale, d'investissement, d'emploi, de résultat net des entreprises et de salaires. Tech. rep., LIEPP Sciences Po.

CARd, D., CARdoso, A. R., Heining, J. and Kline, P. (2018). Firms and labor market inequality: Evidence and some theory. Journal of Labor Economics, 36 (S1), S13-S70.

Chetty, R., Friedman, J. N., Olsen, T. and Pistaferri, L. (2011). Adjustment costs, firm responses, and micro vs. macro labor supply elasticities: Evidence from danish tax records. The quarterly journal of economics, 126 (2), 749-804.

Dube, A., Giuliano, L. and LeOnARD, J. (2015). Fairness and Frictions: The Impact of Unequal Raises on Quit Behavior. Discussion Papers 9149, IZA.

FABRE, T. (2012). Le crédit d'impôt pour la compétitivité et l'emploi déçoit. Challenges.

Fuest, C., Peichl, A. and Siegloch, S. (2018). Do higher corporate taxes reduce wages? micro evidence from germany. American Economic Review, 108 (2), 393-418.

GARIN, A. and SILVÉRIO, F. (2019). How responsive are wages to demand within the firm? evidence from idiosyncratic export demand shocks. Working paper.

GOUX, D. and MAURIN, E. (1999). Persistence of interindustry wage differentials: a reexamination using matched worker-firm panel data. Journal of labor Economics, 17 (3), 492-533.

GUISO, L., PISTAFERRI, L. and SCHIVARDI, F. (2005). Insurance within the firm. Journal of Political Economy, 113 (5), 1054-1087.

HOWELL, S. and BROWN, J. D. (2019). Do cash windfalls affect wages? evidence from r\&d grants to small firms. Evidence from RED Grants to Small Firms (September 2019).

Kleven, H. J. (2016). Bunching. Annual Review of Economics, 8, 435-464.

— and WASEEM, M. (2013). Using notches to uncover optimization frictions and structural elasticities: Theory and evidence from pakistan. The Quarterly Journal of Economics, 128 (2), 669-723.

Kline, P., Petkova, N., Williams, H. and Zidar, O. (2019). Who profits from patents? rent-sharing at innovative firms. The Quarterly Journal of Economics, 134 (3), 1343-1404. 
KRAMARZ, F. and MiCHAUd, M.-L. (2010). The shape of hiring and separation costs in france. Labour Economics, 17 (1), 27-37.

LAMAdon, T., Mogstad, M. and SETZLER, B. (2018). Imperfect competition and rent sharing in the us labor market. University of Chicago mimeo.

LiU, L. and Altshuler, R. (2013). Measuring the burden of the corporate income tax under imperfect competition. National Tax Journal, 66 (1), 215-238.

MANNING, A. (2003). Monopsony in motion: Imperfect competition in labor markets. Princeton University Press.

MCCRARY, J. (2008). Manipulation of the running variable in the regression discontinuity design: A density test. Journal of Econometrics, 142 (2), 698-714.

OECD (2012). Economic policy reforms: Going for growth 2012.

SAEZ, E. (2010). Do tax payers bunch at kink points? American Economic Journal: Economic Policy, 2 (3), 180-212.

-, Matsaganis, M. and Tsakloglou, P. (2012). Earnings Determination and Taxes: Evidence From a Cohort-Based Payroll Tax Reform in Greece. The Quarterly Journal of Economics, 127 (1), 493-533.

-, Schoefer, B. and Seim, D. (2019). Payroll taxes, firm behavior, and rent sharing: Evidence from a young workers' tax cut in sweden. American Economic Review, 109 (5), 1717-63.

SERrato, J. C. S. and ZIDAR, O. (2018). The structure of state corporate taxation and its impact on state tax revenues and economic activity. Journal of Public Economics, $167,158-176$.

Slattery, C. R. and ZidAR, O. M. (2020). Evaluating state and local business tax incentives. National Bureau of Economic Research.

SuÁrez SERrATO, J. C. and ZidAR, O. (2016). Who benefits from state corporate tax cuts? a local labor markets approach with heterogeneous firms. The American Economic Review, 106 (9), 2582-2624.

VERDUGO, G. (2016). Real wage cyclicality in the eurozone before and during the great recession: Evidence from micro data. European Economic Review, 82, 46-69.

WEBER, C. E. (2014). Toward obtaining a consistent estimate of the elasticity of taxable income using difference-in-differences. Journal of Public Economics, 117, 90-103. 


\section{APPENDIX}

\section{A Empirical appendix: robustness tests and additional results}

\section{A.1 Descriptive statistics}

Figure A1: Distribution of firm-level treatment intensity size in 2013 and 2014

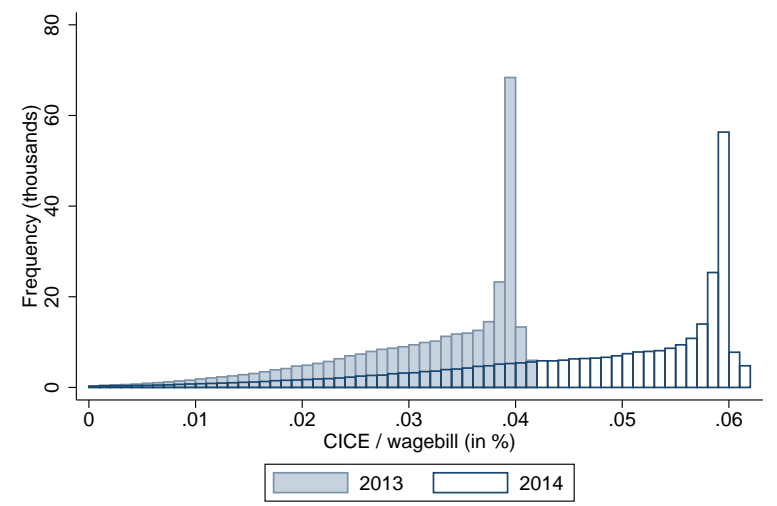

All firms

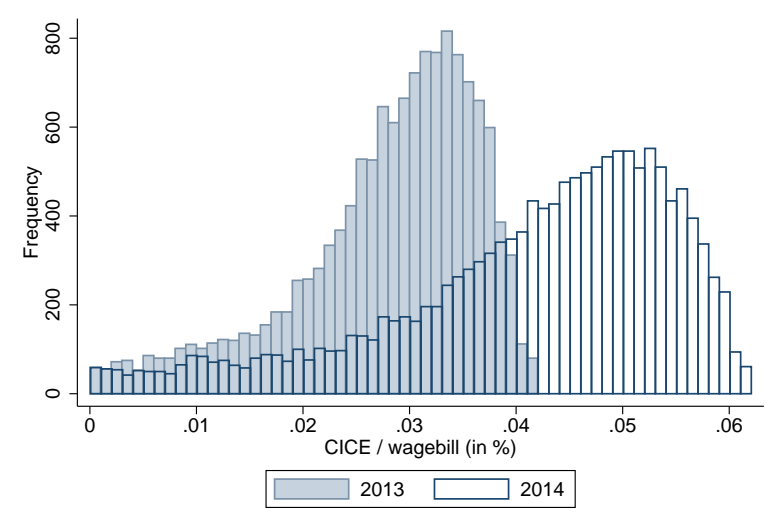

50-249 employees

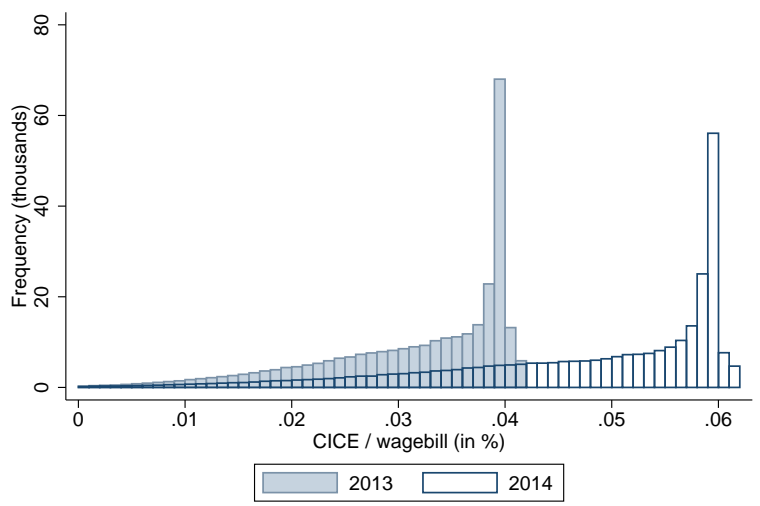

$<50$ employees

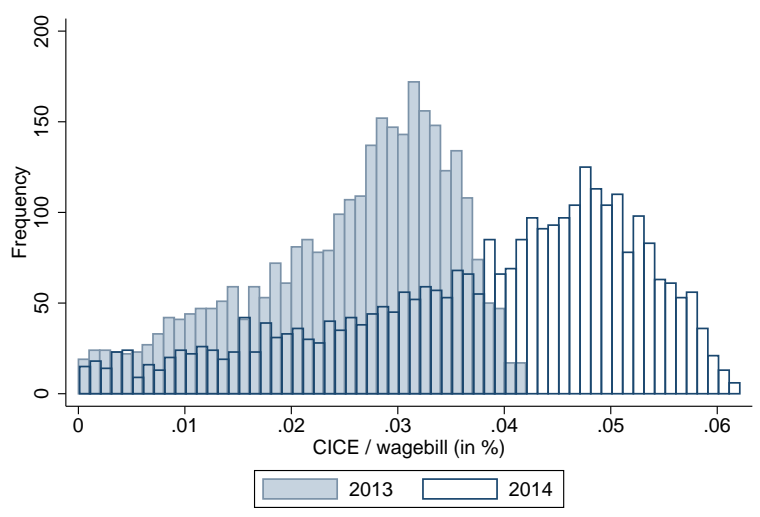

$\geqslant 250$ employees

Notes: Treatment intensity is defined as the amount of tax credit with respect to the firm's wage bill. Sources: DADS, MVC \& FARE, 20132014. 
Table A1: Descriptive statistics of subsamples

\begin{tabular}{lccc}
\hline \hline & All & $>30 \%$ & $>50 \%$ \\
\hline Employment and wage & & & \\
\# of employees & 64.36 & 25.36 & 10.67 \\
\# of high-skill workers & 12.52 & 11.12 & 4.21 \\
\# of low-skill workers & 34.01 & 9.04 & 3.98 \\
Mean wage & 16.03 & 19.65 & 20.26 \\
Mean wage high-skill workers & 22.33 & 22.73 & 22.38 \\
Mean wage low-skill workers & 13.75 & 16.32 & 16.96 \\
Wage stucture & & & \\
Mean wage bill (in k $€$ ) & 876.8 & 590.5 & 214.2 \\
Mean share of <1.6MW in WB & 0.56 & 0.24 & 0.18 \\
Mean share of $<2.5 \mathrm{MW}$ in WB & 0.83 & 0.69 & 0.67 \\
Firm performance & & & \\
Mean sales (in k $€$ ) & 6463 & 3876 & 1244 \\
Mean EBIT (in k $€$ ) & 234 & 245 & 67 \\
Mean VA per worker (in k $€$ ) & 70.1 & 85.8 & 96 \\
Mean assets (in k $€$ ) & 3378.3 & 2902.9 & 538.2 \\
Mean profitability (EBIT/sales) & $3.618 \%$ & $6.326 \%$ & $5.376 \%$ \\
Industries & & & \\
Share in manufacturing & 0.15 & 0.11 & 0.09 \\
Share in construction & 0.17 & 0.18 & 0.18 \\
Share in retail & 0.42 & 0.32 & 0.31 \\
Share in services & 0.18 & 0.33 & 0.37 \\
Share in other & 0.04 & 0.02 & 0.02 \\
\hline Number of firms & 328693 & 30258 & 8172 \\
\hline \hline
\end{tabular}

Notes: This table presents descriptive statistics for the balanced estimation samples depending on restrictions regarding the 2012 share of the wage bill accruing to workers whose hourly wage lays between 2.2 and 2.8 MW. Statistics are displayed for all firms in Column (1), for firms whose payroll share of eligible workers exceeds $30 \%$ in Column (2), for firms whose payroll share of eligible workers exceeds $50 \%$ in Column (3). 


\section{A.2 Firm-level outcomes}

\section{A.2.1 Identification Strategy}

Figure A2: Distribution of wages by treatment intensity

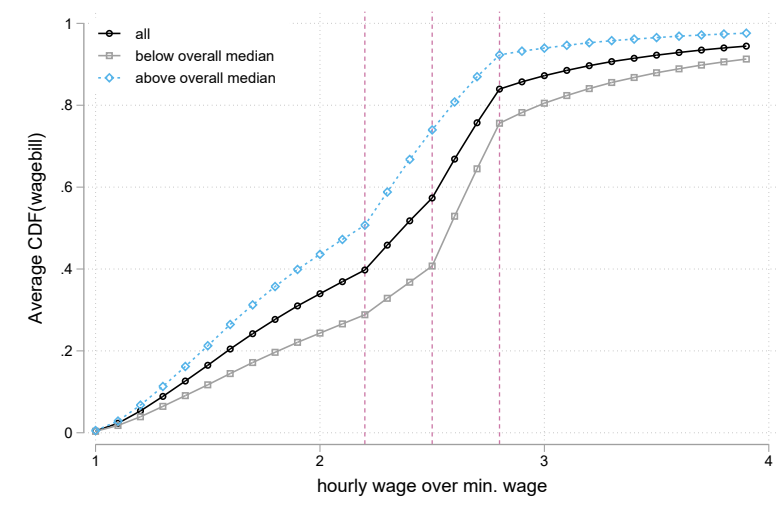

a. Median defined globally

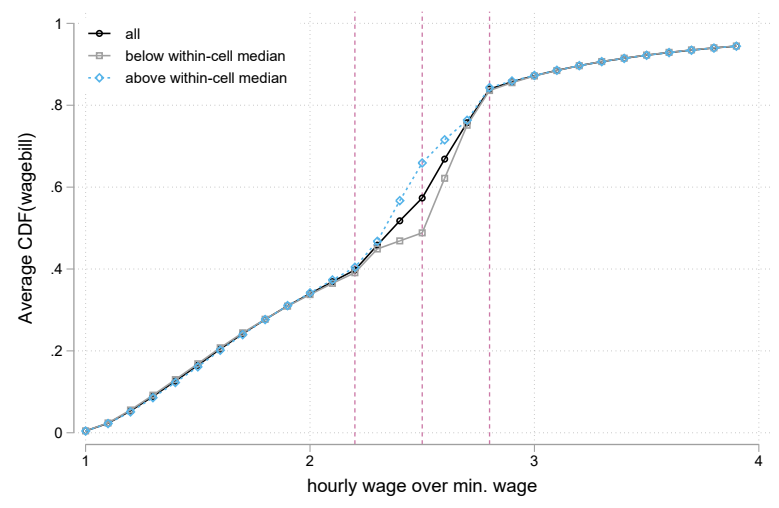

b. Median within bin

Notes: This figure displays the cumulative density function of wages depending on whether they lie above or below the median of the treatment intensity. For the left panel figure, the median is defined for the entire sample. For the left panel figure, the median is now defined within each bin. The sample is here restricted to firms for which more than $30 \%$ of the wage bill accrue to workers paid between 2.2 and 2.8 MW. Red vertical lines refers to 2.2 and $2.8 \mathrm{MW}$.

Table A2: Correlation between treatment intensity and covariates

\begin{tabular}{lccccc}
\hline \hline$(1)$ & $(2)$ & $(3)$ & $(4)$ & $\begin{array}{c}(5) \\
\text { Sector } \times \text { Size }\end{array}$ & $\begin{array}{c}(6) \\
\text { Sector } \times \text { Size } \\
\times \text { Bins FEs }\end{array}$ \\
Statistic & Sample & \# firms & Uncondit. & FEs & -0.003 \\
\hline$\rho\left(Z_{i}, \ln\right.$ Assets $)$ & all & 325,329 & -0.161 & -0.096 & -0.007 \\
$\rho\left(Z_{i}, \ln \left(V A_{i} / L_{i}\right)\right)$ & all & 325,329 & -0.336 & -0.280 & 0.000 \\
$\rho\left(Z_{i}\right.$, Sh $\left.1.5 M W_{i}\right)$ & all & 325,329 & 0.604 & 0.507 & -0.006 \\
\hline$\rho\left(Z_{i}, \ln A s s e t s_{i}\right)$ & $\% \mathrm{WB} \geq 30 \%$ & 30,089 & -0.054 & -0.023 & -0.025 \\
$\rho\left(Z_{i}, \ln \left(V A_{i} / L_{i}\right)\right)$ & $\% \mathrm{WB} \geq 30 \%$ & 30,089 & -0.187 & -0.181 & 0.011 \\
$\rho\left(Z_{i}, S h 1.5 M W_{i}\right)$ & $\% \mathrm{WB} \geq 30 \%$ & 30,089 & 0.353 & 0.316 & -0.030 \\
$\rho\left(Z_{i}, \ln A s s e t s_{i}\right)$ & $\% \mathrm{WB} \geq 50 \%$ & 8,130 & -0.017 & -0.033 & -0.041 \\
$\rho\left(Z_{i}, \ln \left(V A_{i} / L_{i}\right)\right)$ & $\% \mathrm{WB} \geq 50 \%$ & 8,130 & -0.079 & -0.097 & 0.019 \\
$\rho\left(Z_{i}, S h 1.5 M W_{i}\right)$ & $\% \mathrm{WB} \geq 50 \%$ & 8,130 & 0.179 & 0.228 & \\
\hline \hline
\end{tabular}

Notes: A bin is defined as a unique value of the proportion of wage bill accruing to workers making less than 2.2 and less than $2.8 \mathrm{MW}$ (both variables are discretized through truncation into 31 values). $\rho\left(Z_{i}, X_{i}\right)$ is the coefficient of correlation between the instrument for treatment intensity $Z_{i}$ and the firm's characteristics $X_{i}$ in 2012. "\% WB $>x$ " refers to a sample restriction to firms whose share of the wage bill constituted of wages between 2.2 and $2.8 \mathrm{MW}$ is above $x$. Column (4) show unconditional correlations. Column (5) shows the correlation between the two variables after absorbing 3-digit sector $\times$ size FEs. Column (6) shows the correlation between the same variables after absorbing sector $\times$ size $\times$ bins FEs. 


\section{A.2.2 Bin definition}

Figure A3: Robustness to alternative definitions of bins

(a) Alternative bin widths

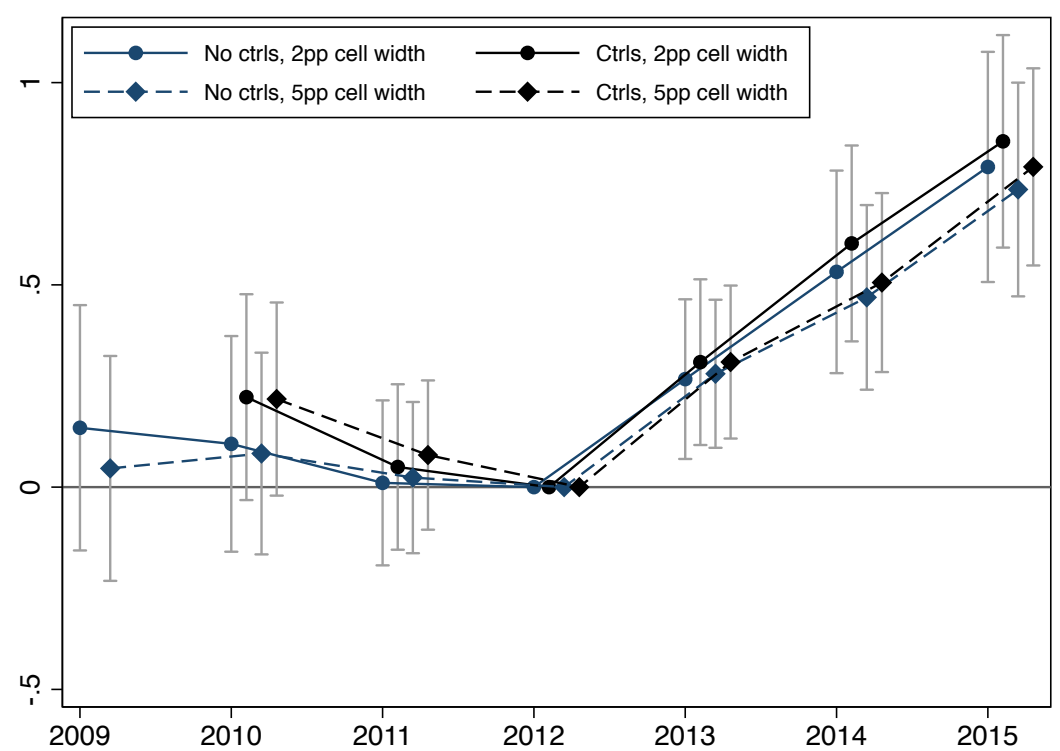

Notes: This figure reports robustness of point estimates and 95-percent confidence intervals from the event study regression defined in Equation 3 with alternative bin widths. Other notes as in Figure 5.

(b) Alternative wage thresholds

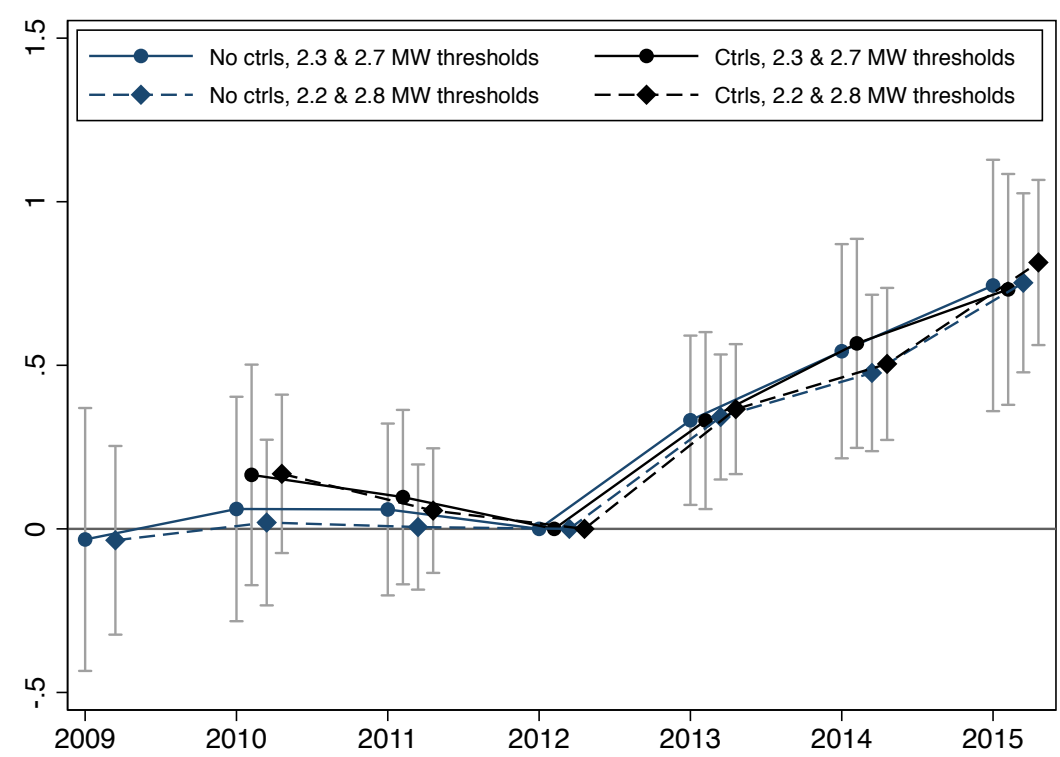

Notes: This figure reports robustness of point estimates and 95-percent confidence intervals from the event study regression defined in Equation 3 with alternative wage thresholds (2.3 and 2.7 MW instead of 2.2 and 2.8 MW) used to define bins. Other notes as in Figure 5. 
Table A3: Impact on hourly wages, DiD

Finer grid, 2 percentage points bins width

\begin{tabular}{lccccccccc}
\hline & $(1)$ & $(2)$ & $(3)$ & $(4)$ & $(5)$ & $(6)$ & $(7)$ & $(8)$ & $(9)$ \\
\hline$Z_{i} \times \mathbb{1}\{t \geq 2013\}$ & $0.317^{* * *}$ & $0.346^{* * *}$ & $0.327^{* * *}$ & $0.380^{* * * *}$ & $0.398^{* * *}$ & $0.393^{* * *}$ & $0.464^{* * *}$ & $0.491^{* * *}$ & $0.500^{* * *}$ \\
& $(0.0692)$ & $(0.0656)$ & $(0.0597)$ & $(0.0832)$ & $(0.0789)$ & $(0.0712)$ & $(0.12)$ & $(0.116)$ & $(0.104)$ \\
\hline Observations & 732508 & 627864 & 612453 & 145117 & 124386 & 120538 & 40530 & 34740 & 33466 \\
$R^{2}$ & 0.933 & 0.940 & 0.945 & 0.852 & 0.865 & 0.877 & 0.758 & 0.774 & 0.798 \\
Window defining cells & $(2.2,2.8)$ & $(2.2,2.8)$ & $(2.2,2.8)$ & $(2.2,2.8)$ & $(2.2,2.8)$ & $(2.2,2.8)$ & $(2.2,2.8)$ & $(2.2,2.8)$ & $(2.2,2.8)$ \\
\% WB in window & 0 & 0 & 0 & 0.3 & 0.3 & 0.3 & 0.5 & 0.5 & 0.5 \\
Width Cells & .02 & .02 & .02 & .02 & .02 & .02 & .02 & .02 & .02 \\
Lagged Controls & & & $\sqrt{ }$ & & & $\sqrt{ }$ & & & $\sqrt{ }$ \\
\hline
\end{tabular}

Notes: Each regression includes a set of bin $\times$ size $(4$ categories $) \times$ sector (3-digit) $\times$ year fixed-effects. Bins are defined as a unique combination of the proportion of wage bill accruing to workers making less than 2.2 and less than 2.8 times the minimum wage (both variables are discretized through truncation into 51 values). Lagged controls include (log of) value added per workers, asset value and the 2012 payroll share of workers earning less than 1.5 MW interacted with year dummies. Robust standard errors in parentheses, clustered at the firm level, ${ }^{*} p<0.1{ }^{* *} p<0.05,{ }^{* * *} p<0.01$. Sources: DADS, FARE, MVC 2009-2015.

Table A4: Impact on hourly wages, $\mathrm{DiD}$

Larger grid, 5 percentage points bin width

\begin{tabular}{lccccccccc}
\hline & $(1)$ & $(2)$ & $(3)$ & $(4)$ & $(5)$ & $(6)$ & $(7)$ & $(8)$ & $(9)$ \\
\hline$Z_{i} \times \mathbb{1}\{t \geq 2013\}$ & $0.295^{* * *}$ & $0.318^{* * *}$ & $0.288^{* * *}$ & $0.407^{* * *}$ & $0.416^{* * *}$ & $0.390^{* * *}$ & $0.457^{* * *}$ & $0.459^{* * *}$ & $0.439^{* * *}$ \\
& $(0.0610)$ & $(0.0579)$ & $(0.0526)$ & $(0.0760)$ & $(0.0721)$ & $(0.0652)$ & $(0.112)$ & $(0.106)$ & $(0.0956)$ \\
\hline Observations & 924623 & 792534 & 773242 & 179760 & 154080 & 149399 & 47943 & 41094 & 39573 \\
$R^{2}$ & 0.929 & 0.937 & 0.942 & 0.857 & 0.871 & 0.882 & 0.766 & 0.782 & 0.804 \\
Window defining cells & $(2.2,2.8)$ & $(2.2,2.8)$ & $(2.2,2.8)$ & $(2.2,2.8)$ & $(2.2,2.8)$ & $(2.2,2.8)$ & $(2.2,2.8)$ & $(2.2,2.8)$ & $(2.2,2.8)$ \\
\% WB in window & 0 & 0 & 0 & 0.3 & 0.3 & 0.3 & 0.5 & 0.5 & 0.5 \\
Width Cells & .05 & .05 & .05 & .05 & .05 & .05 & .05 & .05 & .05 \\
Lagged Controls & & & $\sqrt{ }$ & & & $\sqrt{ }$ & & & $\sqrt{ }$ \\
\hline
\end{tabular}

Notes: Each regression includes a set of bin $\times$ size $(4$ categories $) \times$ sector $(3$-digit $) \times$ year fixed-effects. Bins are defined as a unique combination of the proportion of wage bill accruing to workers making less than 2.2 and less than 2.8 times the minimum wage (both variables are discretized through truncation into 21 values). Lagged controls include (log of) value added per workers, asset value and the 2012 payroll share of workers earning less than $1.5 \mathrm{MW}$ interacted with year dummies. Robust standard errors in parentheses, clustered at the firm level, ${ }^{*} p<0.1{ }^{* *} p<0.05,{ }^{* * *} p<0.01$. Sources: DADS, FARE, MVC 2009-2015. 
Table A5: Impact on hourly wages, DiD

\section{3-2.7 MW window, 3.33 percentage points bin width}

\begin{tabular}{lccccccccc}
\hline & $(1)$ & $(2)$ & $(3)$ & $(4)$ & $(5)$ & $(6)$ & $(7)$ & $(8)$ & $(9)$ \\
\hline$Z_{i} \times \mathbb{1}\{t \geq 2013\}$ & $0.263^{* * *}$ & $0.277^{* * *}$ & $0.240^{* * *}$ & $0.311^{* * *}$ & $0.302^{* * *}$ & $0.265^{* * *}$ & $0.518^{* * *}$ & $0.499^{* * *}$ & $0.457^{* * *}$ \\
& $(0.0793)$ & $(0.0753)$ & $(0.0684)$ & $(0.102)$ & $(0.0974)$ & $(0.0885)$ & $(0.159)$ & $(0.151)$ & $(0.137)$ \\
\hline Observations & 678062 & 581196 & 566727 & 87598 & 75084 & 72729 & 21973 & 18834 & 18163 \\
$R^{2}$ & 0.936 & 0.943 & 0.948 & 0.846 & 0.859 & 0.871 & 0.760 & 0.778 & 0.801 \\
Window defining cells & $(2.3,2.7)$ & $(2.3,2.7)$ & $(2.3,2.7)$ & $(2.3,2.7)$ & $(2.3,2.7)$ & $(2.3,2.7)$ & $(2.3,2.7)$ & $(2.3,2.7)$ & $(2.3,2.7)$ \\
\% WB in window & 0 & 0 & 0 & 0.3 & 0.3 & 0.3 & 0.5 & 0.5 & 0.5 \\
Width Cells & .033 & .033 & .033 & .033 & .033 & .033 & .033 & .033 & .033 \\
Lagged Controls & & & $\sqrt{ }$ & & & $\sqrt{ }$ & & & $\sqrt{ }$ \\
\hline
\end{tabular}

Notes: Each regression includes a set of bin $\times$ size $(4$ categories $) \times$ sector (3-digit) $\times$ year fixed-effects. Bins are defined as a unique combination of the proportion of wage bill accruing to workers making less than 2.3 and less than 2.7 times the minimum wage (both variables are discretized through truncation into 31 values). Lagged controls include (log of) value added per workers, asset value and the 2012 payroll share of workers earning less than 1.5 MW interacted with year dummies. Robust standard errors in parentheses, clustered at the firm level, ${ }^{*} p<0.1,{ }^{* *} p<0.05,{ }^{* * *} p<0.01$. Sources: DADS, FARE, MVC 2009-2015.

Table A6: Impact on hourly wages, DiD

\section{3-2.7 MW window, 5 percentage points bin width}

\begin{tabular}{lccccccccc}
\hline & $(1)$ & $(2)$ & $(3)$ & $(4)$ & $(5)$ & $(6)$ & $(7)$ & $(8)$ & $(9)$ \\
\hline$Z_{i} \times \mathbb{1}\{t \geq 2013\}$ & $0.269^{* * *}$ & $0.288^{* * *}$ & $0.244^{* * *}$ & $0.296^{* * *}$ & $0.309^{* * *}$ & $0.263^{* * *}$ & $0.462^{* * *}$ & $0.504^{* * *}$ & $0.476^{* * *}$ \\
& $(0.0863)$ & $(0.0818)$ & $(0.0744)$ & $(0.108)$ & $(0.102)$ & $(0.0928)$ & $(0.167)$ & $(0.159)$ & $(0.145)$ \\
\hline Observations & 574420 & 492360 & 480388 & 76636 & 65688 & 63761 & 19740 & 16920 & 16373 \\
$R^{2}$ & 0.938 & 0.945 & 0.949 & 0.840 & 0.855 & 0.866 & 0.766 & 0.782 & 0.803 \\
Window defining cells & $(2.3,2.7)$ & $(2.3,2.7)$ & $(2.3,2.7)$ & $(2.3,2.7)$ & $(2.3,2.7)$ & $(2.3,2.7)$ & $(2.3,2.7)$ & $(2.3,2.7)$ & $(2.3,2.7)$ \\
\% WB in window & 0 & 0 & 0 & 0.3 & 0.3 & 0.3 & 0.5 & 0.5 & 0.5 \\
Width Cells & .02 & .02 & .02 & .02 & .02 & .02 & .02 & .02 & .02 \\
Lagged Controls & & & $\sqrt{ }$ & & & $\sqrt{ }$ & & & $\sqrt{ }$ \\
\hline
\end{tabular}

Notes:Each regression includes a set of bin $\times$ size $(4$ categories $) \times$ sector $(3$-digit $) \times$ year fixed-effects. Bins are defined as a unique combination of the proportion of wage bill accruing to workers making less than 2.3 and less than 2.7 times the minimum wage (both variables are discretized through truncation into 21 values). Lagged controls include (log of) value added per workers, asset value and the 2012 payroll share of workers earning less than 1.5 MW interacted with year dummies. Robust standard errors in parentheses, clustered at the firm level, ${ }^{*} p<0.1,{ }^{* *} p<0.05,{ }^{* *} p<0.01$. Sources: DADS, FARE, MVC 2009-2015. 
Table A7: Impact on hourly wages, DiD

\section{3-2.7 MW window, 2 percentage points bin width}

\begin{tabular}{lccccccccc}
\hline & $(1)$ & $(2)$ & $(3)$ & $(4)$ & $(5)$ & $(6)$ & $(7)$ & $(8)$ & $(9)$ \\
\hline$Z_{i} \times \mathbb{1}\{t \geq 2013\}$ & $0.236^{* * *}$ & $0.258^{* * *}$ & $0.226^{* * *}$ & $0.301^{* * *}$ & $0.307^{* * *}$ & $0.273^{* * *}$ & $0.490^{* * *}$ & $0.489^{* * *}$ & $0.457^{* * * *}$ \\
& $(0.0754)$ & $(0.0717)$ & $(0.0651)$ & $(0.0994)$ & $(0.0946)$ & $(0.0858)$ & $(0.156)$ & $(0.148)$ & $(0.134)$ \\
\hline Observations & 737772 & 632376 & 616776 & 94710 & 81180 & 78698 & 23478 & 20124 & 19425 \\
$R^{2}$ & 0.933 & 0.941 & 0.946 & 0.845 & 0.859 & 0.870 & 0.756 & 0.774 & 0.796 \\
Window defining cells & $(2.3,2.7)$ & $(2.3,2.7)$ & $(2.3,2.7)$ & $(2.3,2.7)$ & $(2.3,2.7)$ & $(2.3,2.7)$ & $(2.3,2.7)$ & $(2.3,2.7)$ & $(2.3,2.7)$ \\
\% WB in window & 0 & 0 & 0 & 0.3 & 0.3 & 0.3 & 0.5 & 0.5 & 0.5 \\
Width Cells & .05 & .05 & .05 & .05 & .05 & .05 & .05 & .05 & .05 \\
Lagged Controls & & & $\sqrt{ }$ & & & $\sqrt{ }$ & & & $\sqrt{ }$ \\
\hline
\end{tabular}

Notes: Each regression includes a set of bin $\times$ size $(4$ categories $) \times$ sector $(3$-digit $) \times$ year fixed-effects. Bins are defined as a unique combination of the proportion of wage bill accruing to workers making less than 2.3 and less than 2.7 times the minimum wage (both variables are discretized through truncation into 51 values). Lagged controls include (log of) value added per workers, asset value and the 2012 payroll share of workers earning less than 1.5 MW interacted with year dummies. Robust standard errors in parentheses, clustered at the firm level, ${ }^{*} p<0.1,{ }^{* *} p<0.05,{ }^{* *} p<0.01$. Sources: DADS, FARE, MVC 2009-2015. 


\section{A.2.3 Treatment intensity based on other years}

Figure A4: Robustness to alternative definitions of the instrument

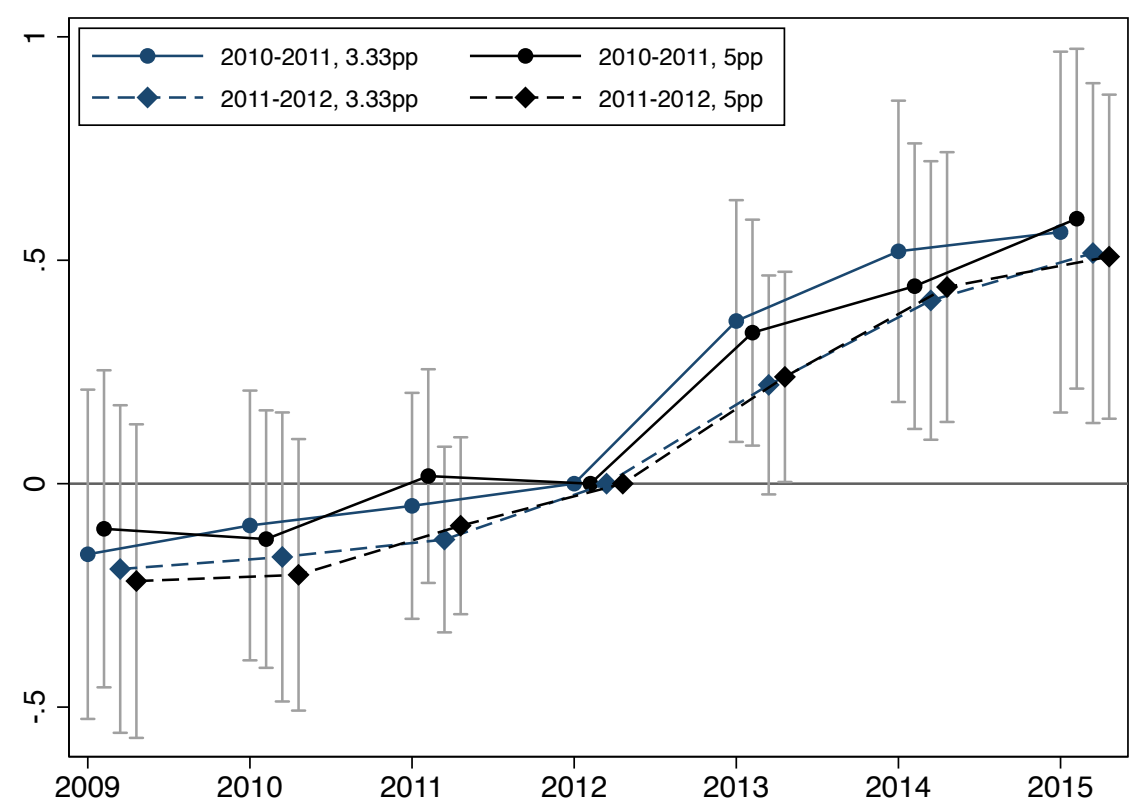

Notes: This figure reports robustness of point estimates and 95-percent confidence intervals from the event study regression defined in Equation 3 with different years (2010 and 2011 or 2011 and 2012 as opposed to just 2012 in the baseline analysis) used to build the instrument and construct the bins. Other notes as in Figure 5. 
Figure A5: Placebo test - Effect on wages

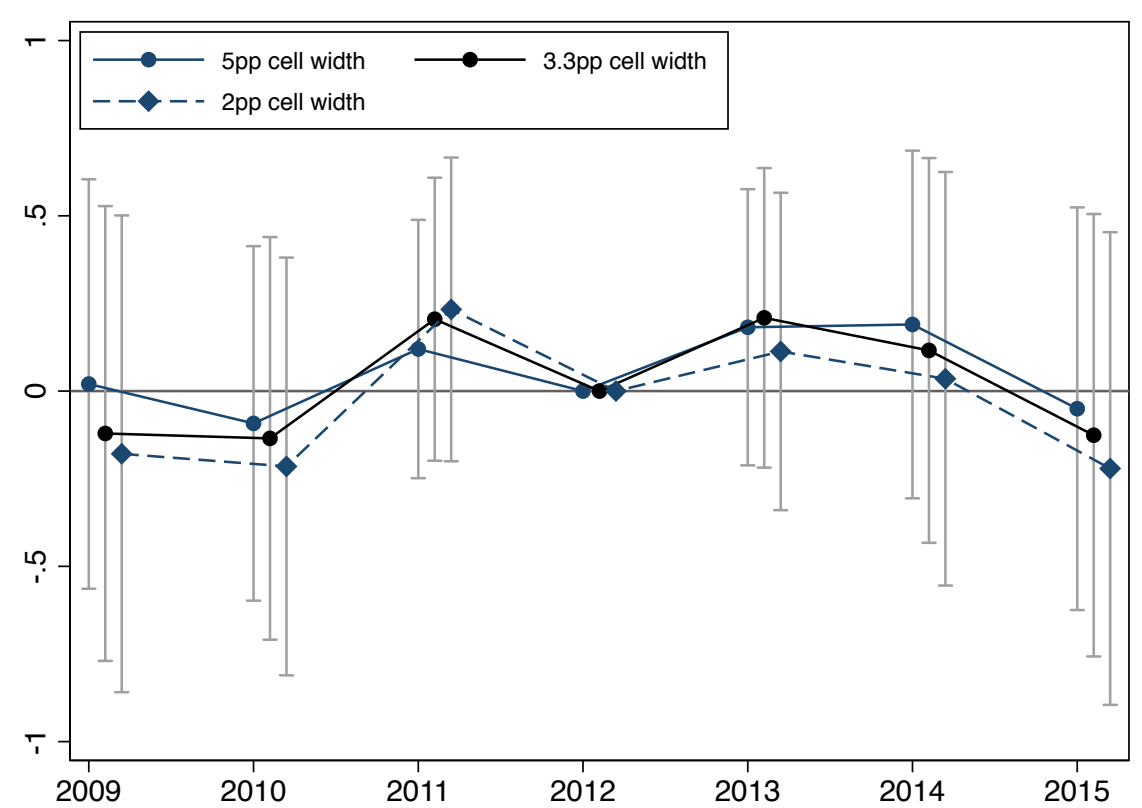

Notes: This figure reports placebo test of the effects of the tax credit on gross hourly wages. We estimate the effect of a placebo reform with features similar to the CICE, except that the wage eligibility cut-off is 3.1 MW instead of 2.5 MW. We define bins accordingly, using 2.9 and 3.3 MW wage thresholds. The 3.1 MW threshold is used for no other policy, we therefore expect no effect. Estimates are based on the sample of firms with at least $50 \%$ of their wage bill accruing to workers paid between 2.9 and $3.3 \mathrm{MW}$. Other notes as in Figure 5.

Table A8: Robustness for treatment intensity based on other years (5pp width)

\begin{tabular}{|c|c|c|c|c|c|c|}
\hline \multirow[b]{3}{*}{$Z_{i} \times \mathbb{1}\{t \geq 2013\}$} & \multicolumn{6}{|c|}{ Mean gross hourly wage, weighted by hours worked (log) } \\
\hline & & 2010-2011 & & & 2011-2012 & \\
\hline & $\begin{array}{c}0.149^{* *} \\
(0.0598)\end{array}$ & $\begin{array}{l}0.303^{* * *} \\
(0.0795)\end{array}$ & $\begin{array}{c}0.482^{* * *} \\
(0.120)\end{array}$ & $\begin{array}{l}0.170^{* * *} \\
(0.0611)\end{array}$ & $\begin{array}{l}0.296^{* * *} \\
(0.0802)\end{array}$ & $\begin{array}{c}0.469^{* * *} \\
(0.121)\end{array}$ \\
\hline Obs & 952,587 & 129 , & 29 , & 945,322 & & 29,422 \\
\hline$R^{2}$ & 0.940 & 0.881 & 0.810 & 0.940 & 0.879 & 0.808 \\
\hline Wind & $(2.2,2.8)$ & $(2.2,2.8)$ & $(2.2,2.8)$ & $(2.2,2.8)$ & $(2.2,2.8)$ & $(2.2,2.8)$ \\
\hline Bin & $5 \mathrm{pp}$ & $5 p p$ & $5 p p$ & $5 p p$ & $5 p p$ & $5 p p$ \\
\hline & $>0 \%$ & $>30 \%$ & $>50 \%$ & $>0 \%$ & $>30 \%$ & $>50 \%$ \\
\hline Lagged controls & Yes & Yes & Yes & Yes & Yes & Yes \\
\hline
\end{tabular}

Notes: This table reports the estimated impact of the CICE on mean hourly wage. The unit of observation is the firm. The dependent variable is the mean gross hourly wage of workers weighted by hours worked. The independent variable is the payroll share of workers earning less than $2.5 \mathrm{MW}$ multiplied by the tax credit rate in years 2010 and 2011 (left panel) or 2011 and 2012 (right panel) and interacted with an indicator variable equal to one after 2013. Other notes as in Table 2. 
Table A9: Robustness for treatment intensity based on other years (3.33pp width)

\begin{tabular}{|c|c|c|c|c|c|c|}
\hline \multirow[b]{3}{*}{$Z_{i} \times \mathbb{1}\{t \geq 2013\}$} & \multicolumn{6}{|c|}{ Mean gross hourly wage, weighted by hours worked (log) } \\
\hline & \multicolumn{3}{|c|}{ 2010-2011 } & \multicolumn{3}{|c|}{ 2011-2012 } \\
\hline & $\begin{array}{c}0.143^{* *} \\
(0.0637)\end{array}$ & $\begin{array}{l}0.315^{* * *} \\
(0.0842)\end{array}$ & $\begin{array}{c}0.497^{* * *} \\
(0.126)\end{array}$ & $\begin{array}{l}0.172^{* * *} \\
(0.0647)\end{array}$ & $\begin{array}{l}0.291^{* * *} \\
(0.0843)\end{array}$ & $\begin{array}{c}0.465^{* * *} \\
(0.126)\end{array}$ \\
\hline Obs & 887,3 & 116,7 & 26,7 & 881,169 & 117,785 & 26,418 \\
\hline$R^{2}$ & 0.943 & 0.883 & 0.812 & 0.942 & 0.882 & 0.810 \\
\hline Winc & $(2.2,2.8)$ & $(2.2,2.8)$ & $(2.2,2.8)$ & $(2.2,2.8)$ & $(2.2,2.8)$ & $(2.2,2.8)$ \\
\hline Bin & 3.33pp & $3.33 \mathrm{pp}$ & $3.33 \mathrm{pp}$ & $3.33 \mathrm{pp}$ & 3.33pp & $3.33 \mathrm{pp}$ \\
\hline & $>0 \%$ & $>30 \%$ & $>50 \%$ & $>0 \%$ & $>30 \%$ & $>50 \%$ \\
\hline Lagged controls & Yes & Yes & Yes & Yes & Yes & Yes \\
\hline
\end{tabular}

Notes: This table reports the estimated impact of the CICE on the mean hourly wage of workers by skill groups. The unit of observation is the firm. The dependent variable is the mean gross hourly wage of workers weighted by hours worked. The independent variable is the payroll share of workers earning less than 2.5 MW multiplied by the tax credit rate in years 2010 and 2011 (left panel) or 2011 and 2012 (right panel) and interacted with an indicator variable equal to one after 2013. Other notes as in Table 2. 


\section{A.2.4 Heterogeneity among incumbents}

Table A10: Heterogeneity across skill levels among incumbents

\begin{tabular}{lccccccc}
\hline \hline & \multicolumn{3}{c}{ Mean gross hourly wage, weighted by hours worked (log) } \\
\cline { 2 - 4 } \cline { 7 - 8 }$Z_{i} \times \mathbb{1}\{t \geq 2013\}$ & \multicolumn{3}{c}{ low-skill workers } & & \multicolumn{3}{c}{ High-skill workers } \\
\cline { 2 - 4 } \cline { 7 - 8 } & -0.047 & -0.048 & -0.087 & & $0.437^{* * *}$ & $0.420^{* * *}$ & $0.605^{* * *}$ \\
& $(0.078)$ & $(0.103)$ & $(0.163)$ & & $(0.102)$ & $(0.118)$ & $(0.157)$ \\
\hline Observations & 616,093 & 99,010 & 23,379 & & 528,764 & 91,246 & 23,245 \\
$R^{2}$ & 0.888 & 0.870 & 0.869 & & 0.866 & 0.826 & 0.765 \\
Window & $(2.2,2.8)$ & $(2.2,2.8)$ & $(2.2,2.8)$ & & $(2.2,2.8)$ & $(2.2,2.8)$ & $(2.2,2.8)$ \\
Bin width & $3.33 \mathrm{pp}$ & $3.33 \mathrm{pp}$ & $3.33 \mathrm{pp}$ & & $3.33 \mathrm{pp}$ & $3.33 \mathrm{pp}$ & $3.33 \mathrm{pp}$ \\
Sample & $>0 \%$ & $>30 \%$ & $>50 \%$ & & $>0 \%$ & $>30 \%$ & $>50 \%$ \\
Lagged controls & $Y e s$ & $Y e s$ & Yes & & Yes & Yes & Yes \\
\hline \hline
\end{tabular}

Notes: This table reports the estimated impact of the CICE on the mean hourly wage of workers by skill groups. The unit of observation is the firm. The dependent variable is the mean gross hourly wage of workers weighted by hours worked. The independent variable is the 2012 payroll share of workers earning less than 3.1 MW multiplied by the tax credit rate and interacted with an indicator variable equal to one after 2013. Other notes as in Table 2.

Table A11: Heterogeneity across genders among incumbents

\begin{tabular}{lccccccc}
\hline \hline & \multicolumn{3}{c}{ Mean gross hourly wage, weighted by hours worked (log) } \\
\cline { 2 - 4 } \cline { 7 - 8 }$Z_{i} \times \mathbb{1}\{t \geq 2013\}$ & \multicolumn{3}{c}{ Women } & \multicolumn{4}{c}{ Men } \\
\cline { 2 - 4 } \cline { 7 - 8 } & $0.299^{* * *}$ & $0.331^{* * *}$ & $0.490^{* * *}$ & & $0.457^{* * *}$ & $0.527^{* * *}$ & $0.663^{* * *}$ \\
& $(0.0953)$ & $(0.118)$ & $(0.174)$ & & $(0.0865)$ & $(0.108)$ & $(0.150)$ \\
\hline Observations & 572,937 & 92,825 & 21,973 & & 628,855 & 107,956 & 27,445 \\
$R^{2}$ & 0.888 & 0.870 & 0.869 & & 0.866 & 0.826 & 0.765 \\
Window & $(2.2,2.8)$ & $(2.2,2.8)$ & $(2.2,2.8)$ & & $(2.2,2.8)$ & $(2.2,2.8)$ & $(2.2,2.8)$ \\
Bin width & $3.33 \mathrm{pp}$ & $3.33 \mathrm{pp}$ & $3.33 \mathrm{pp}$ & & $3.33 \mathrm{pp}$ & $3.33 \mathrm{pp}$ & $3.33 \mathrm{pp}$ \\
Sample & $>0 \%$ & $>30 \%$ & $>50 \%$ & & $>0 \%$ & $>30 \%$ & $>50 \%$ \\
Lagged controls & Yes & Yes & Yes & & Yes & Yes & Yes \\
\hline \hline
\end{tabular}

Notes: This table reports the estimated impact of the CICE tax credit on wages of workers by gender. The unit of observation is the firm. The dependent variable is the mean gross hourly wage of continuing workers of a given gender, weighted by hours worked. Other notes as in Table A10. 


\section{A.2.5 Impact on Sales}

Figure A6: Impact on sales (in log)

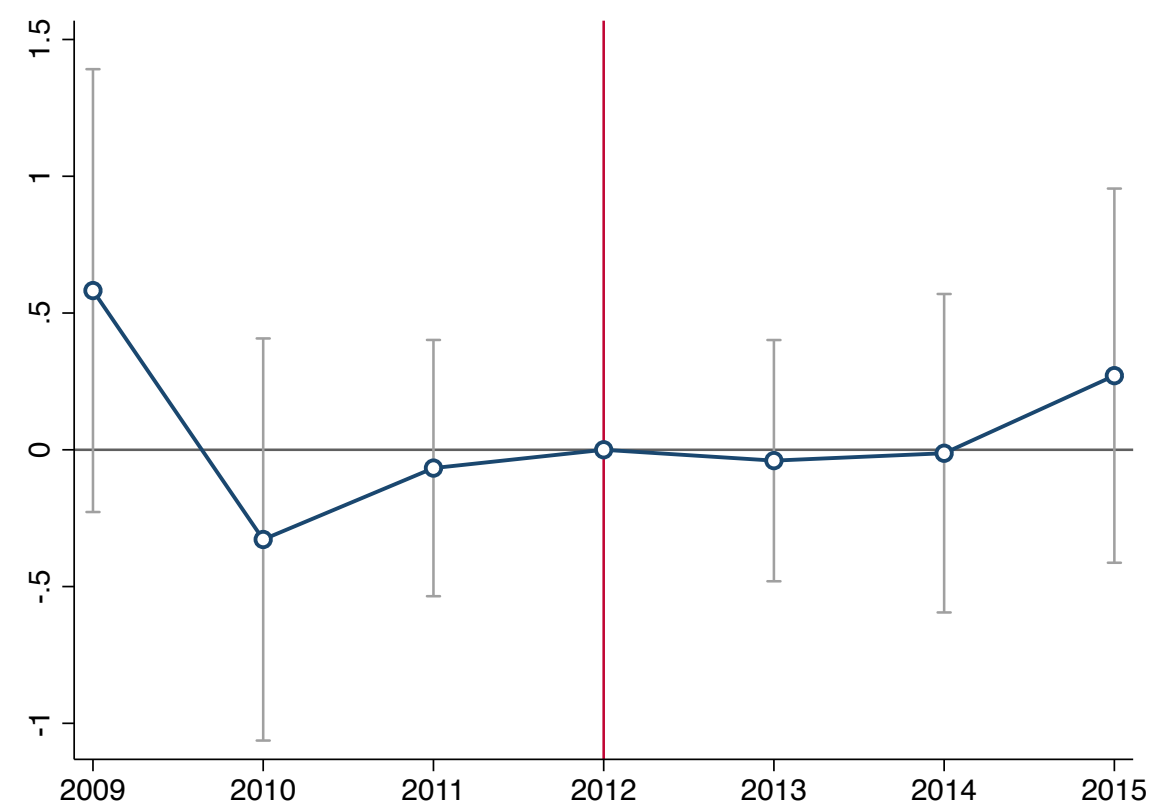

Notes: This figure reports the estimated impact of the CICE tax credit on wages of high-skill workers. Other notes as in Figure 5. 


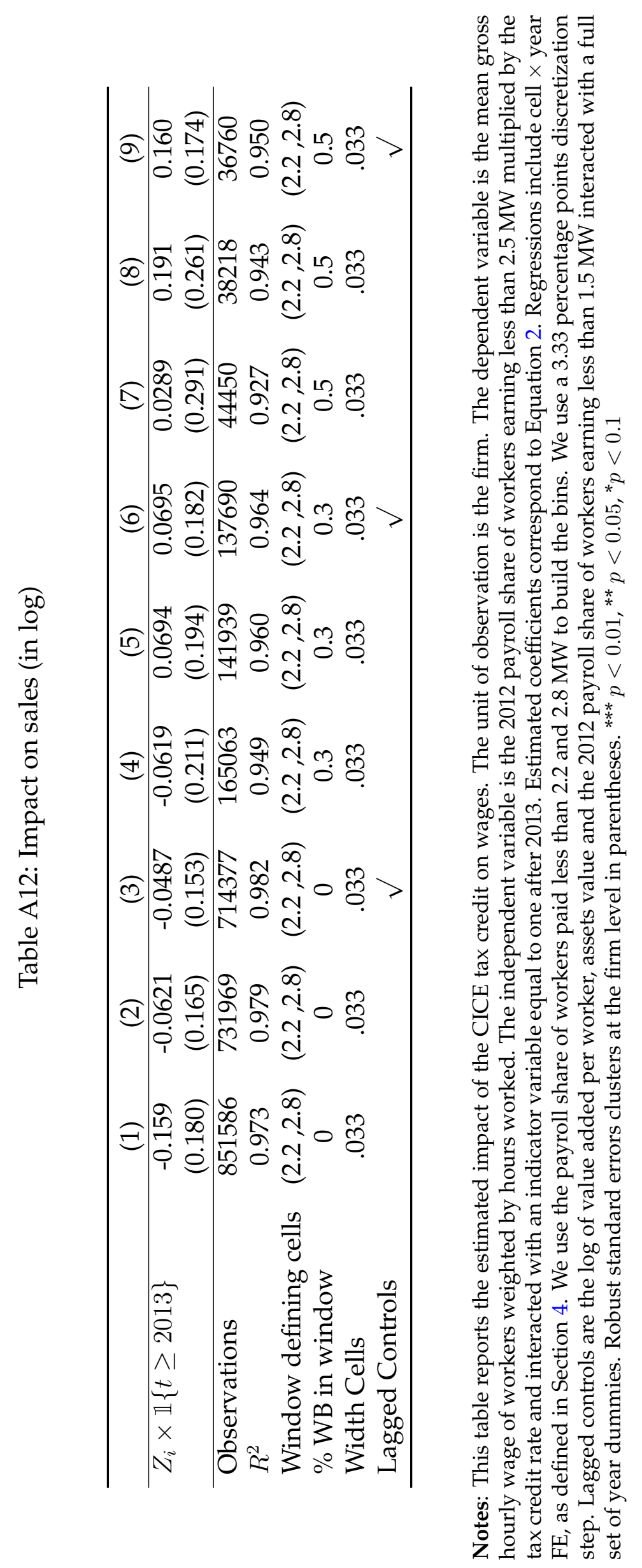




\section{A.2.6 Retention Rate}

Figure A7: Impact on employee retention rate by skill group (30\% sample)

(a) High-skill workers

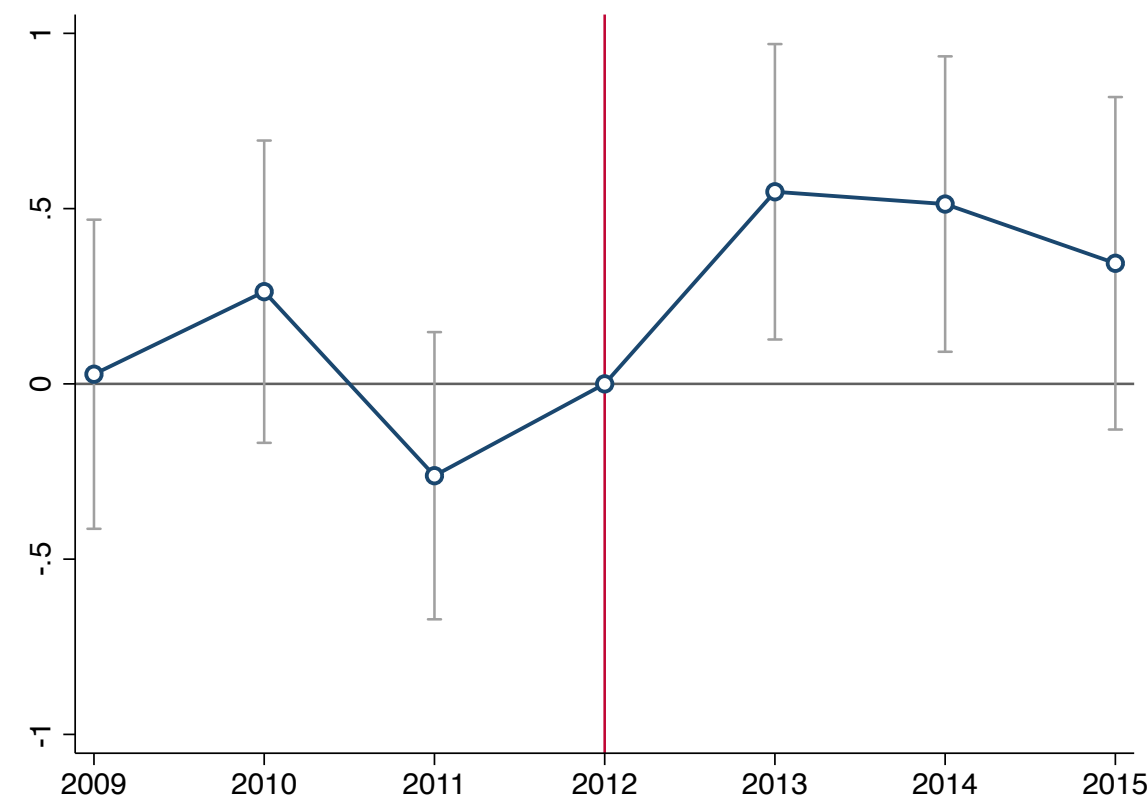

Notes: This figure reports the estimated impact of the CICE tax credit on wages of high-skill workers. Other notes as in Figure 5.

(b) low-skill workers

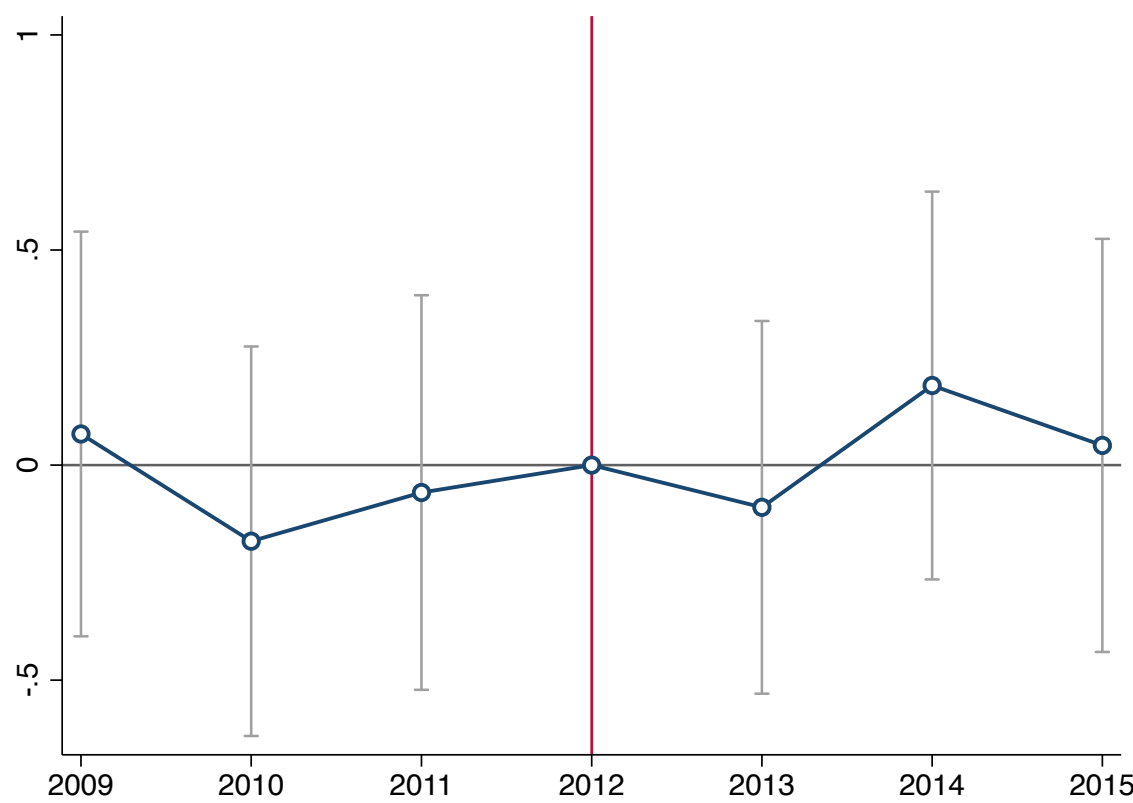

Notes: This figure reports the estimated impact of the CICE tax credit on wages of low-skill workers. Other notes as in Figure 5. 
Figure A8: Impact on employee retention rate by skill group (50\% sample)

(a) High-skill workers

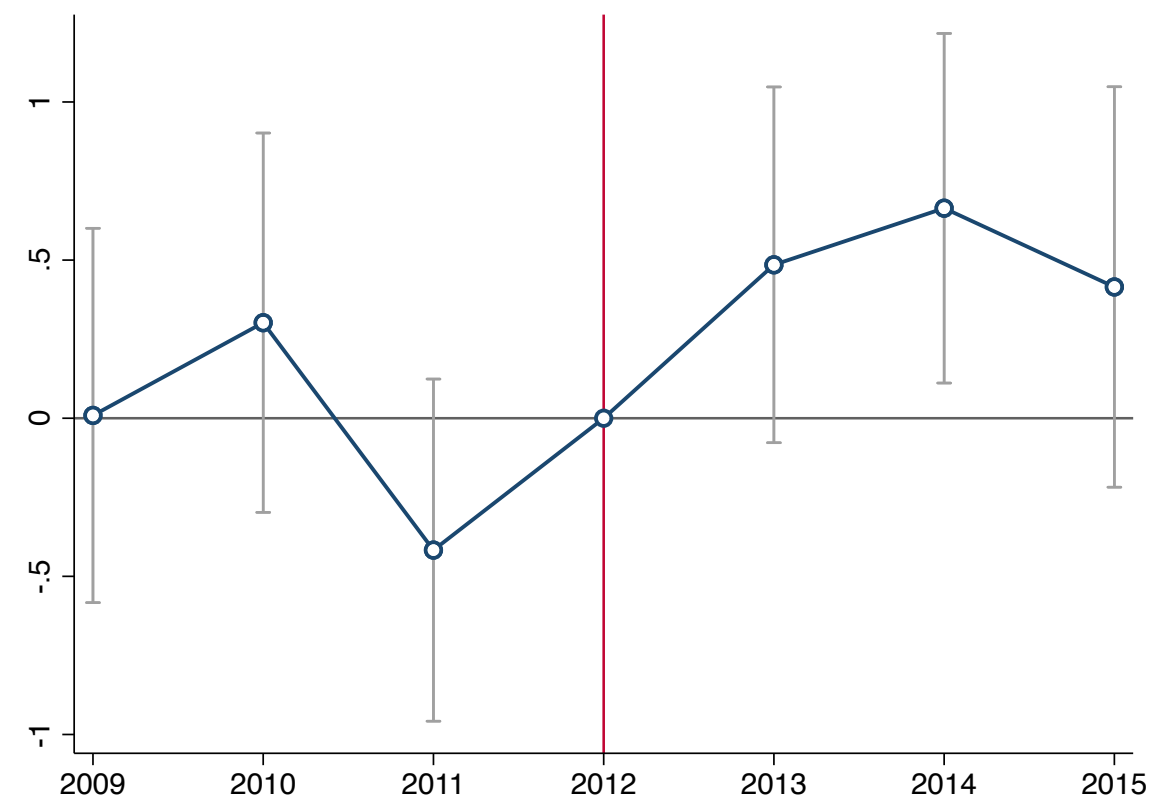

Notes: This figure reports the estimated impact of the CICE tax credit on wages of high-skill workers. Other notes as in Figure 5.

(b) Low-skill workers

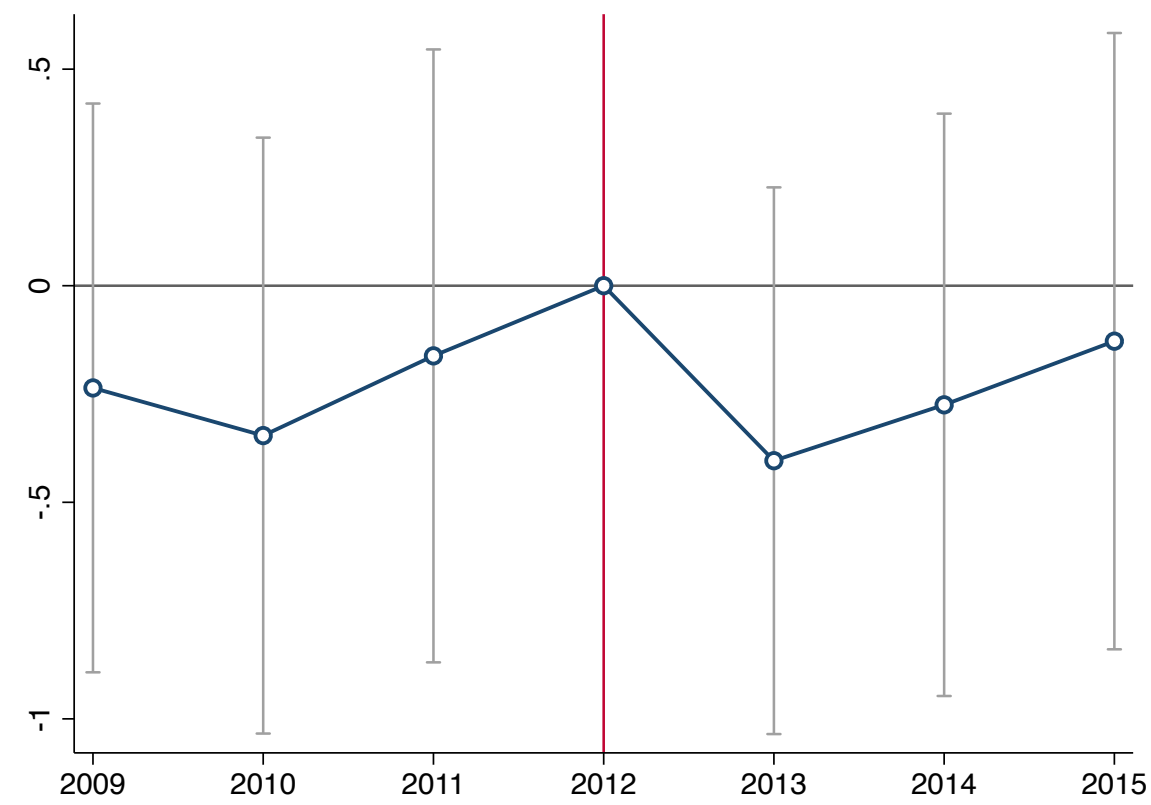

Notes: This figure reports the estimated impact of the CICE tax credit on wages of low-skill workers. Other notes as in Figure 5. 


\section{A.3 Employee-level outcomes}

\section{A.3.1 Distribution of continuing employees' wage growth}

We formally test for a potential deformation of the distribution around the $2.5 \mathrm{MW}$ threshold for years after the reform. As for new hires, we test for a local deformation in the relationship between wage growth and initial wage of incumbents. ${ }^{38}$ We model employee wage growth $g_{i}$ as a $n^{\text {th }}$ order polynomial of initial wage $w_{0, i}$. We fit this polynomial excluding a range of observations around the cut-off $\left[w_{L}, w_{U}\right]$ and get a vector of polynomial coefficients denoted $\beta$. We then predict the average wage growth within the exclusion range using the mean wage in the range. We note $\bar{X}$ the vector of mean wage in the range to the power $p=0, \ldots, n . \bar{X}=\left[1, \overline{w_{0}^{1}}, \overline{w_{0}^{2}}, \ldots, \overline{w_{0}^{n}}\right]$, where $\overline{w_{0}^{p}}$. We compare the observed mean wage growth $\bar{g}$ with the mean counterfactual wage growth $\hat{g}=\bar{X}^{\prime} \hat{\beta}^{n}$ in the exclusion range. We test the significance of $\hat{G}=\bar{g}-\hat{g}$ under the assumption that the two estimators are independent.

Table A13: Growth distortion estimation

\begin{tabular}{cccc}
\hline \hline Excluded range & & Pre-reform & Post-reform \\
\cline { 1 - 1 }$[2.45,2.55]$ & & -0.00025 & 0.00069 \\
& & $(0.00075)$ & $(0.00082)$ \\
{$[2.40,2.60]$} & & 0.00015 & 0.00084 \\
& & $(0.00079)$ & $(0.00086)$ \\
{$[2.35,2.65]$} & & 0.00017 & 0.00097 \\
& & $(0.00087)$ & $(0.00095)$ \\
{$[2.30,2.70]$} & & 0.00034 & 0.0011 \\
& & $(0.00097)$ & $(0.0011)$ \\
\hline \hline
\end{tabular}

Notes: Coefficients are the difference between the mean observed and counterfactual wage growth in the exclusion range. The sample only includes employees working in firms that claimed the tax credit and that are in our firm-level estimation sample. Wage growth is computed only for continuing workers with a permanent contract. Standard errors in parentheses. ${ }^{*}: \mathrm{p}<0.05 ;{ }^{* *}: \mathrm{p}<0.01{ }^{* * *}: \mathrm{p}<0.001$.

\footnotetext{
${ }^{38}$ Here, however, we do not need to impose that the distribution deformation below the threshold is compensated for above it since we are analyzing a conditional expected value, not a distribution.
} 
Figure A9: Distribution of wage growth of incumbents

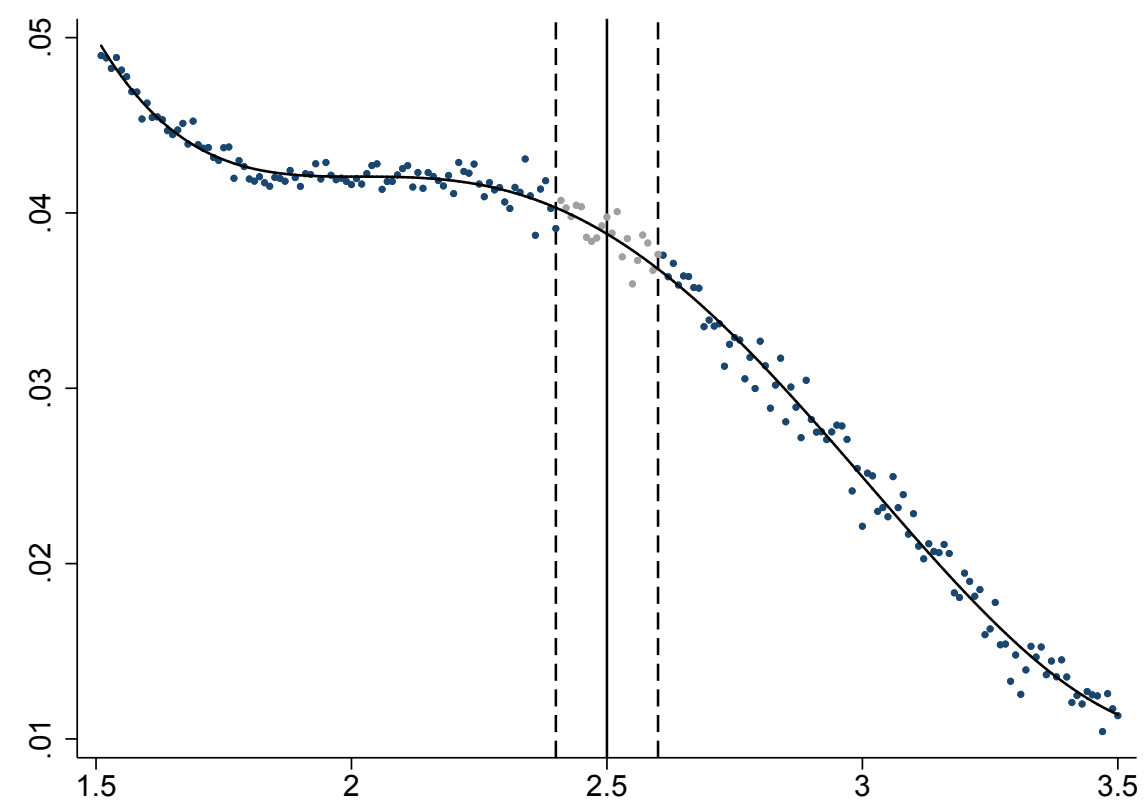

(a) Pre-reform

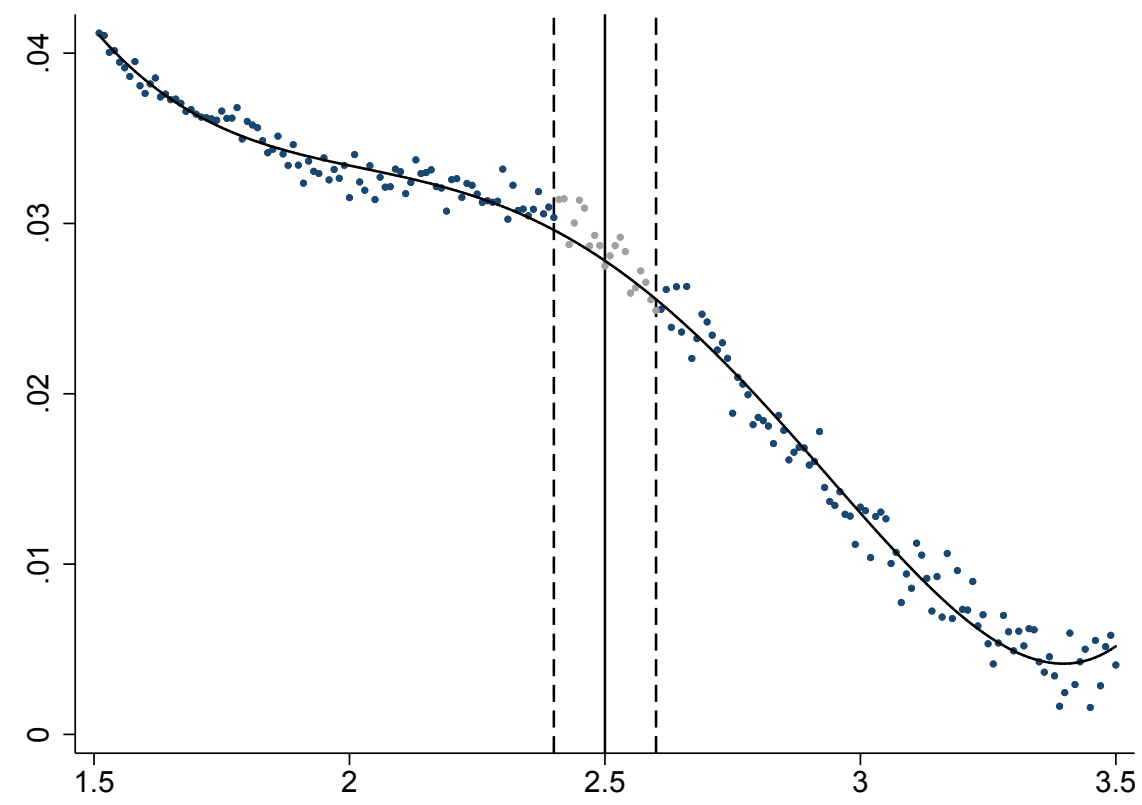

(b) Post-reform

Notes: This figure depicts the relationship between the year-on-year wage growth rate and past year's wage for two time periods, before and after the reform. Wages are expressed in multiples of the minimum wage. Dashed vertical lines illustrate the excluding range $\left[w_{L}, w_{U}\right]$, which here corresponds to [2.4 MW, 2.6 MW]. 


\section{ONLINE APPENDIX}

\section{OA1 Conceptual framework for bunching analysis: a static wage posting model}

We explore how bunching might arise from a discontinuity in the CICE schedule in a simple wage posting model. Consider a setting where each firm has a vacancy associated with an heterogeneous productivity $p$. Workers potentially accepting the offer have a reservation wage distributed according to a cumulative distribution function denoted $H(w)$. The expected profit of a $p$-type firm posting a wage $w$ will therefore write as:

$$
\pi(w, p)=H(w)(p-w)
$$

When setting wages, the firm faces the standard trade off between the increasing the probability of filling a vacancy and increasing the per vacancy profit in case it is filled. We assume that $\pi(w, p)$ is strictly concave in $p$ which holds under standard conditions on the cumulative distribution function $H() .{ }^{39}$ Interpreted as a direct subsidy on labor paid below a given hourly threshold, the CICE introduces a notch in the labor cost schedule thus modifying the expected profit function as follows:

$$
\pi(w, p, s)=H(w)\left(p-w\left(1-s \mathbb{1}_{\left\{w \leq w_{T}\right\}}\right)\right)
$$

where $s$ is the subsidy rate of the CICE and $w_{T}$ is the wage threshold above which it does not apply. In this context, firms with values of $p$ falling in a given range $S=$ $\left[p_{L}, p_{H}\right]$ will have an incentive to bunch and propose wage at $w_{T}$. The lower bound of the set $S$ is determined by the firm which was optimally choosing to set wage at $w_{T}$ before the policy, i.e.

$$
p_{L}=\left\{p: \pi^{\prime}\left(w_{T}, p, 0\right)=0\right\}
$$

The upper bound corresponds to the firm that is indifferent between proposing wage exceeding $w_{T}$ and therefore not benefiting from the tax credit and setting a wage equal to $w_{T}$ and keep the eligibility of the program. That is $p_{H}$ is defined as follows:

$$
p_{H}=\left\{p: \max _{w} \pi(w, p, 0)=\pi\left(w_{T}, p, s\right)\right\}
$$

\footnotetext{
${ }^{39}$ The $\pi(p, w)$ to be concave in $w$ it is sufficient that $\partial^{2} \pi(p, w) / \partial w^{2}<0$ which will be true if: $H^{\prime \prime}(w)<0$ which holds for standard distribution such as the Pareto distribution.
} 
Let us denoted $w_{H}$ the profit maximizing wage that the firm whose productivity is equal to $p_{H}$ will post in the absence of subsidy: $w_{H} \equiv \operatorname{argmax} \pi\left(w, p_{H}, 0\right)$. In the case we assumed here, in which the heterogeneity of the wage of new hires is solely determined by the productivity of vacancy-posting firms (heterogeneity in $p^{\prime} \mathrm{s}$ ), the model predicts that there should be a missing mass between $w_{T}$ and $w_{H}$ and an accumulation point at $w_{T}$.

We represent graphically the choice to bunch or not for firms of different productivity level in Figure OA1. The black and blue lines represent the expected profit as a function of posted wage $w$ for the highest and lowest bunching firm respectively. The highest buncher is indifferent between posted $w_{H}$ and $w_{T}$ as it results in the same expected profit.

Figure OA1: Bunching in posted wages in a static model

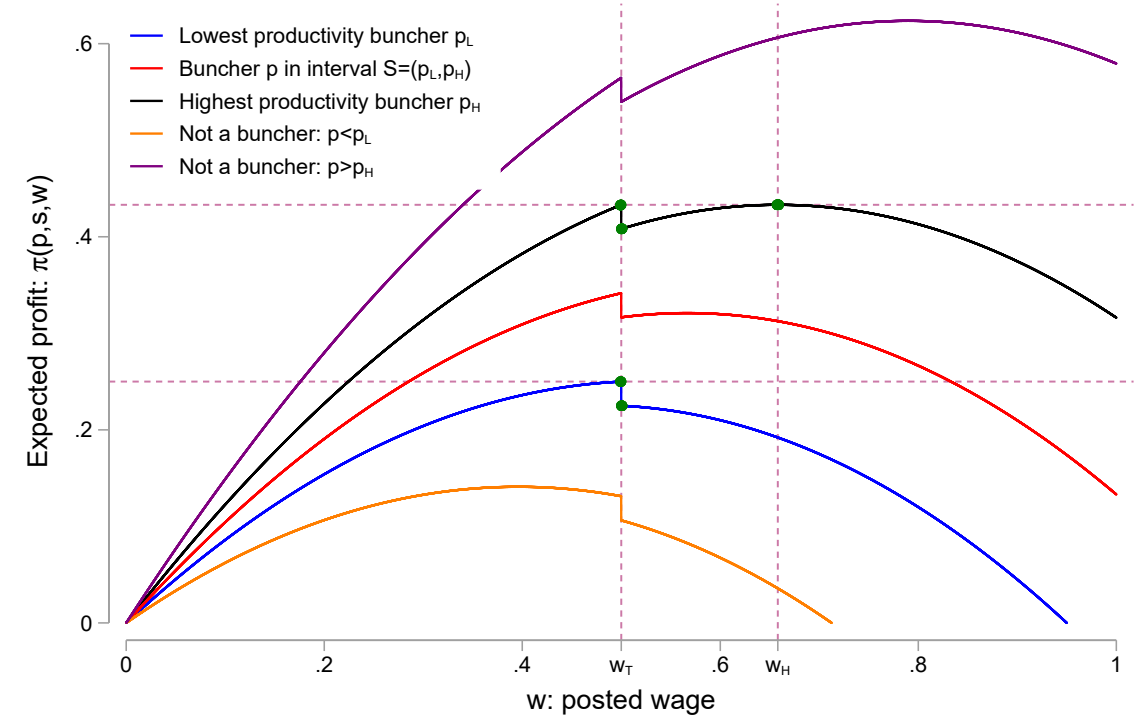

Notes: The model predicts that firms with productivity $p \in\left(p_{L}, p_{H}\right)$ have an incentives to bunch their posted wages at $w_{T}$-i.e. the threshold above which the subsidy rate $s$ ceases to apply. Accordingly, that there should be a missing mass at the right of the threshold $w_{T}$ and bunching, i.e. an accumulation point at threshold $w_{T}$. Here the missing mass region would be $S_{w}=\left(w_{T}, w_{H}\right)$. The figure is drawn assuming $H(w)=w$, i.e. reservation wages follow a standard uniform distribution $U(0,1)$, wage threshold is set at $w_{T}=0.5$ and $s=0.10$.

To further illustrate the potential bunching in that setting, we draw 100,000 random productivity realizations $p$ from a rescaled lognormal distribution and plot the histogram of the resulting posted wage distribution without any notch and with the notch. Results are displayed in figure OA2. The bunching is apparent whenever the notch is introduced. Naturally, in practice there are other sources of heterogeneity underlying the distribution of new hires' wages, moreover optimization frictions might be at play which would lead to a less strict version of bunching Kleven (2016). Still 
we would expected an accumulation point in $w_{T}$ but some missing mass in region $\left(w_{T}, w_{H}\right)$ without a fully zero mass region.

Figure OA2: Bunching in posted wages in a static model

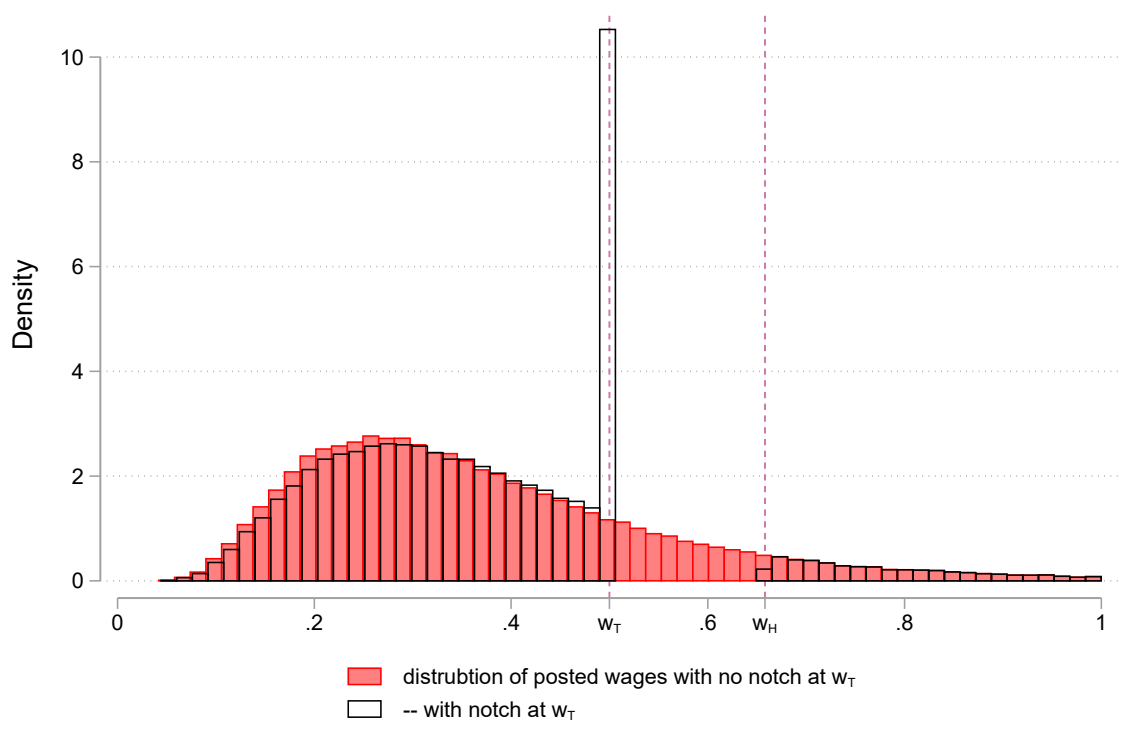

Notes: The figures display the posted wage distribution from a simulation of 100,000 productivity draws of random variable $p$. The red bars are represented the distribution without a notch at $w_{T}=.5$ and the black bars are representing the distribution with the notch. The figure is drawn assuming $H(w)=w$,i.e. reservation wages follow a standard uniform distribution $U(0,1)$, wage threshold is set at $w_{T}=0.5$ and $s=0.10$. It further assumes that $p=x / 1.5$ where $x$ is a lognormal distribution with paramters $\mu=0, \sigma=\sqrt{2}$.

\section{OA2 Semi-elasticity as labor share of tax incidence}

Our empirical analysis - see equation (2) - yields an estimate of the semi-elasticity of firm average wage with respect to the effective tax credit rate, where the effective tax credit rate is defined as the amount of tax credit granted per euro spent on the wage bill. Denoting the effective tax credit rate as $s$, we estimate : $\widehat{\beta}=\frac{d w / w}{s}$. Here we build on standard tax incidence analysis - see e.g. section 3.3 of Fuest et al. (2018) - in order to relate this semi-elasticity estimate to the incidence of corporate tax credit on wages. In particular, we are interested in how this estimate relate the share of the total business tax credit falling onto workers.

We consider a simple economy where identical workers have quasi-linear preferences with indirect utility $V(w)$ where $w$ is the wage rate which we measure as the hourly wage. Firms have a profit function which writes:

$$
\Pi=p Y-w L+s w L
$$


where $L$ denotes the number of workers (in terms of effective labor supply), $Y$ the total of output, $p$ the price of output. For simplicity we abstract away from other factors of production such as capital as we do not expect the tax credit to affect their price. As above, the parameter $s$ denotes the effective tax credit rate, that is the amount of tax credit given per euro spent on the wage bill:

$$
s \equiv C I C E / w L=\text { rate of the tax credit } \times \text { share wage bill eligible }
$$

where $C I C E$ refers to total amount of tax credit. We compute overall changes in social welfare $W$ following a marginal change in $s$ :

$$
d W=L d V+d \Pi
$$

The envelop theorem implies $d V=L \frac{d w}{d s} d s$ and $d \Pi=-\frac{d w}{d s} d s L+w L \times d s+s w L$.

Overall change in welfare writes as: $d W=w L \times d s+s w L$. Accordingly the share of the change in welfare falling on labor writes as:

$$
\begin{aligned}
I_{L} \equiv \frac{d V}{d V+d \Pi} & =\frac{L d w}{d w \cdot s L+d s \cdot w L} \\
& =\left(\frac{d w \cdot s L+d s \cdot w L}{L d w}\right)^{-1}=\left(s+\left(\frac{d w / w}{d s}\right)^{-1}\right)^{-1} \\
(\text { assuming } s \approx 0) & =\frac{d w / w}{d s}
\end{aligned}
$$

We see that the semi elasticity of the hourly wage with respect to $s$ can be interpreted as an approximation labor share of tax incidence. As long as the semi elasticity $\frac{d w / w}{d s}$ is large relative to the effective subsidy rate $s$, the approximation is valid. For instance, for a semi elasticity equal to $\widehat{\beta}=0.5$ and the upper bound for an effective tax credit rate of 0.053 - corresponding to a case where all workers are eligible to the tax credit -, the true labor share of incidence is $I_{L}=\left(0.053+(0.5)^{-1}\right)^{-1} \approx 0.487$.

Our main specification - specified in equation (2) - regresses $\ln$ (average hourly wage) on the instrumented empirical counterpart of $s$-defined in equation (1). The coefficient associated denote $\beta$ is an estimate of the elasticity of the average hourly wage with respect to $s$. The estimate $\widehat{\beta}$ can therefore be interpreted as a close approximation of the share of the tax incidence born by labor.

\section{OA3 Reduced-form and structural coefficients}

In the paper, we focus on reduced form estimates. To motivate this choice, consider the main dynamic specification (which is given by equation 3 in the body of the text): 


$$
\ln \left(Y_{i, t}\right)=\alpha_{i}+\alpha_{c, t}+\sum_{\substack{d=2009 \\ d \neq 2012}}^{2015} \beta_{d} \cdot Z_{i} \cdot \mathbb{1}\{d=t\}+X_{i, t-1}^{\prime} \gamma+\varepsilon_{i, t}
$$

The reduced-form estimates from equation (6) reflect the sum of first stage times structural coefficients for different lags. To see this, let us denote $\beta_{t, l}^{\text {s }}$ the structural coefficient representing the marginal effect at time $t$ of the endogenous variable $D_{i t}$ with a lag of $l$ (so-called treatment effect on the treated). We further denote the first-stage relationship between the endogenous variable at time $t$ and the instrument measured in 2012 as $\frac{d D_{t}}{d Z_{2012}}$. The reduced-form or intent-to-treat coefficient in 2013, 2014 and 2015 can then be expressed as:

$$
\begin{aligned}
& \beta_{2013}=\beta_{2013,0}^{\mathbf{s}} \frac{d D_{2013}}{d Z_{2012}} \\
& \beta_{2014}=\beta_{2014,1}^{\mathbf{s}} \frac{d D_{2013}}{d Z_{2012}}+\beta_{2014,0}^{\mathbf{s}} \frac{d D_{2014}}{d Z_{2012}} \\
& \beta_{2015}=\beta_{2015,2}^{\mathbf{s}} \frac{d D_{2013}}{d Z_{2012}}+\beta_{2015,1}^{\mathbf{s}} \frac{d D_{2014}}{d Z_{2012}}+\beta_{2015,0}^{\mathbf{s}} \frac{d D_{2015}}{d Z_{2012}}
\end{aligned}
$$

The main advantage of focusing of the reduced-form is that it allows us to remain agnostic as to the lag structure of the effect of the endogenous variable on wage. The structural coefficients cannot be readily identified without further assumptions - as there 3 equations and 6 structural parameters. For instance, Giupponi and Landais (2018) resort to a stationarity assumption (i.e. $\beta_{t, l}^{\mathbf{s}}=\beta_{t^{\prime}, l}^{\mathbf{s}}$ with $t^{\prime} \neq t$ and $t^{\prime}, t>2012$ ) to recursively identify the structural coefficients. Considering that the policy might take some time to unfold and gain in salience among firms, one might expect effects to vary with calendar time for a given lag, and therefore the assumption is not likely to fit our setting well. Accordingly, we prefer to focus on the reduced-form coefficients.

\section{References:}

Giupponi, G., \& Landais, C. (2018). Subsidizing Labor Hoarding in Recessions: The Employment \& Welfare Effects of Short Time Work. CEP Discussion Paper No 1585 December 2018

\section{OA4 Description of variables used in the analysis}

\section{Employee-level analysis:}

1. Hourly wage variable: we define hourly wage as the ratio of gross earnings (salaire brut) over worked hours in a given job (nombre d'heures). 
2. New hire: Hires are defined as jobs starting in February or later at year $t$ taken up by workers not employed in the same firm at $t-1$. Firms with no employment at year $t-1$ are excluded.

3. Incumbents: Incumbents are defined as workers in permanent contract working full-time (32 hours per week or more) who kept the same occupation within the same firm between $t$ and $t-1$.

\section{Firm-level analysis:}

1. Occupation variable: we define low-skill workers as those whose occupation (variable CS) is documented in DADS database as employee (employé) and blue collar (ouvrier) occupations, we define high-skill workers as those whose occupation is documented as intermediary occupations (professions intermédiaires) or executives and intellectual occupations (cadres et professions intellectuelles).

2. Average hourly wage at the firm-level: this variable is equal to the ratio of the sum of the gross wages accruing to workers in permanent contract (contrat à durée indéterminée) to the sum of worked hours for the same set of workers. We defined low and high-skill mean wage analogously (DADS).

3. Actual treatment intensity: the ratio of the amount of CICE claimed to the tax services and recorded in the MVC database over the sum of gross wages (DADS).

4. Instrument for treatment intensity: the instrument of exposure intensity is the CICE rate times the ratio of the sum of gross wages accruing to workers whose hourly wage is between .85 and $2.5 \mathrm{MW}$ over the sum of overall gross wages (DADS).

5. Grid variable: We compute for each firm the share of the wage bill below 2.2 MW and below 2.8 MW in 2012 (alternative specification with 2.3 and 2.7MW points), the year prior the reform (DADS). We discretize these variables ranging from $0 \%$ to $100 \%$ with a step of 3.33 percentage points (alternative specification with steps of 2 and 5 percentage points). The interaction of these two variables yields the grid.

6. Sectoral variable: The sectoral variable is the variable APEN (DADS) documenting the main activity of the firm through a 3-digit classification.

7. Size variable: The size variable takes on 3 values and is defined based on the full-time equivalent employment variable (DADS). The three values are defined as follows: 1 - less than 50, 2- between 50 and $250,3-250$ or more. 
8. Cell variables: The cell variable is the interaction of grid, sectoral and size variables.

9. Control variables: We include 3 main lagged control variable (1) share of employees paid less than 1.5 MW (DADS), (2) the log value of assets (valeur des immobilisations in FARE), and (3) the log productivity (value-added over average employment in FARE). 